QA: N/A

TDR-CRW-SE-000008 REV 00 ICN 02

January 2002

\title{
Safety Basis Report
}

Prepared for:

U.S. Department of Energy

Yucca Mountain Site Characterization Office

P.O. Box 30307

North Las Vegas, Nevada 89036-0307

Prepared by:

Bechtel SAIC Company, LLC

1180 Town Center Drive

Las Vegas, Nevada 89144

Under Contract Number

DE-AC08-01RW12101 


\section{DISCLAIMER}

This report was prepared as an account of work sponsored by an agency of the United States Government. Neither the United States Government nor any agency thereof, nor any of their employees, nor any of their contractors, subcontractors or their employees, makes any warranty, express or implied, or assumes any legal liability or responsibility for the accuracy, completeness, or any third party's use or the results of such use of any information, apparatus, product, or process disclosed, or represents that its use would not infringe privately owned rights. Reference herein to any specific commercial product, process, or service by trade name, trademark, manufacturer, or otherwise, does not necessarily constitute or imply its endorsement, recommendation, or favoring by the United States Government or any agency thereof or its contractors or subcontractors. The views and opinions of authors expressed herein do not necessarily state or reflect those of the United States Government or any agency thereof. 


\title{
Civilian Radioactive Waste Management System
} Management \& Operating Contractor

\author{
Safety Basis Report
}

TDR-CRW-SE-000008 REV 00 ICN 02

January 2002

Prepared by:
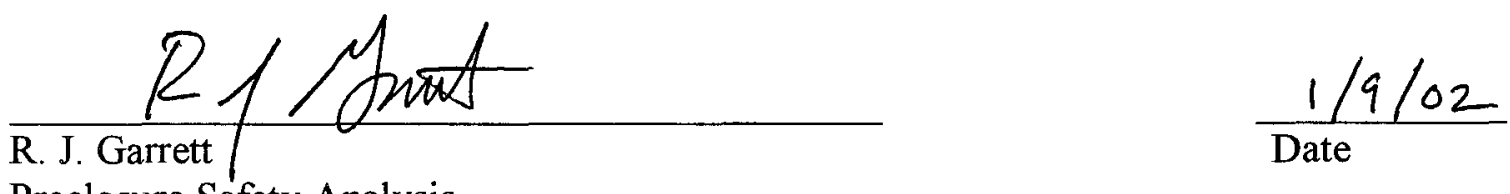

Preclosure Safety Analysis

Endorsed by:

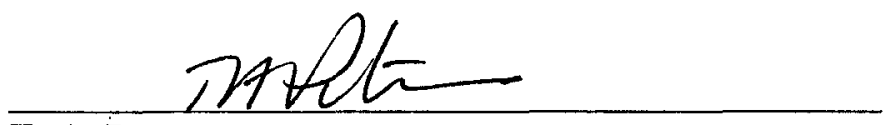

T. A. Peterson

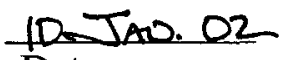

Manager, Site Operations

Approved by:
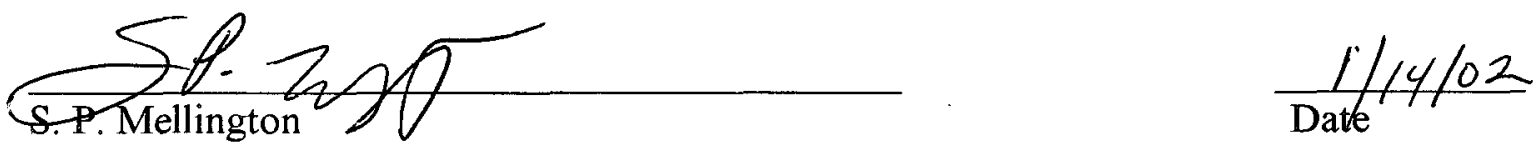

Assistant Manager for the

Office of Project Execution 


\section{REVISION RECORD}

\begin{tabular}{|c|c|c|c|}
\hline $\begin{array}{c}\text { Revision } \\
\text { No. }\end{array}$ & ICN No. & $\begin{array}{c}\text { Effective } \\
\text { Date }\end{array}$ & Description of Change \\
\hline 00 & - & $07 / 14 / 00$ & $\begin{array}{l}\text { Initial issue of Safety Basis Report. Material inventories include } \\
\text { all of Area 25. Functional classification was applied only to the } \\
\text { ESF. }\end{array}$ \\
\hline 00 & 01 & $09 / 8 / 00$ & $\begin{array}{l}\text { Safety Basis Report updated to include all YMP facilities. The } \\
\text { material inventories were updated to be consistent with the } \\
\text { M\&O Materials Inventory database as of } 8 / 31 / 2000 \text {. }\end{array}$ \\
\hline 00 & 02 & $1 / 31 / 02$ & $\begin{array}{l}\text { Safety Basis Report updated to include Emergency Refuge } \\
\text { Chambers located in the Enhanced Characterization of the } \\
\text { Repository Block (ECRB) East-West Cross Drift as well as to } \\
\text { reclassify the Compressed Air System based on the installation } \\
\text { of the Refuge Chambers. }\end{array}$ \\
\hline
\end{tabular}


INTENTIONALLY LEFT BLANK 


\section{CONTENTS}

Page

ACRONYMS, SYMBOLS, AND UNITS

xiii

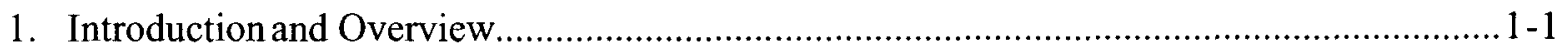

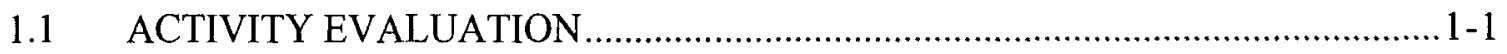

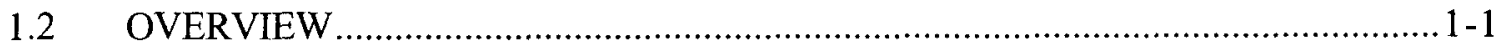

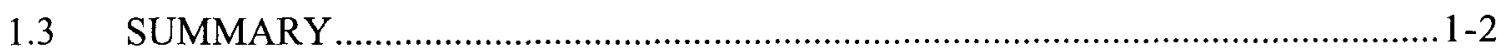

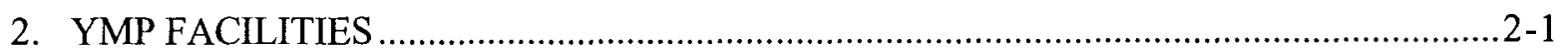

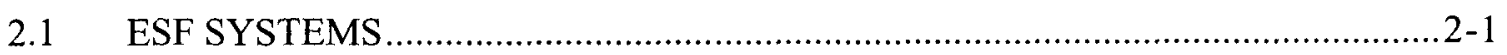

2.1.1 ESF Subsurface Ventilation System .................................................. 2-1

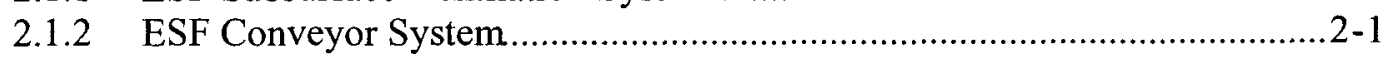

2.1.3 ESF Power System......................................................................... $2-1$

2.1.4 ESF Compressed Air System............................................................. 2-2

2.1.5 ESF Waste Water System..................................................................2 2-2

2.1.6 ESF Material and Personnel Handling System......................................... 2-2

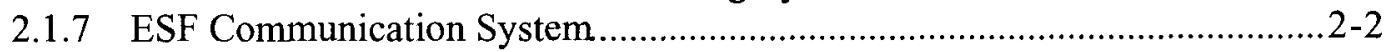

2.1.8 ESF Potable Water System ............................................................ 2-3

2.1.9 ESF Non-Potable Water System ......................................................... $2-3$

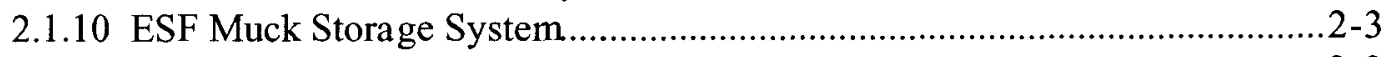

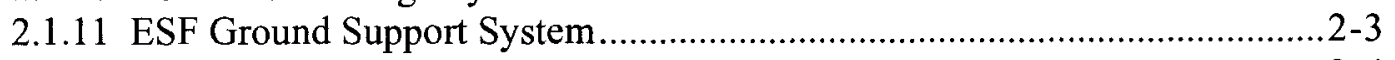

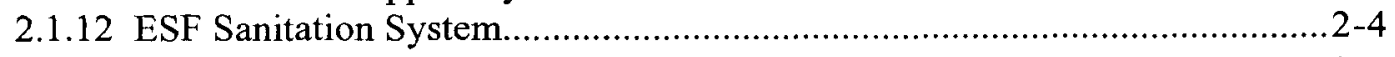

2.1.13 ESF Subsurface Lighting System .................................................... $2-4$

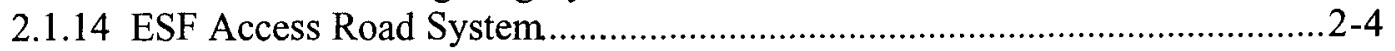

2.1.15 ESF North Portal Pad Drainage System .................................................. 2-4

2.1.16 ESF South Portal Pad Drainage ............................................................ $2-4$

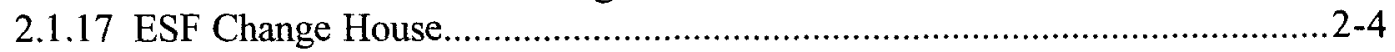

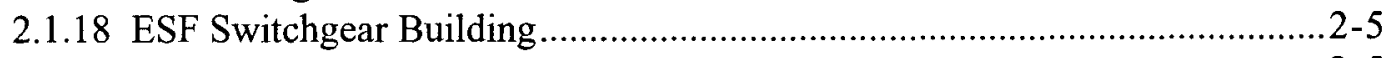

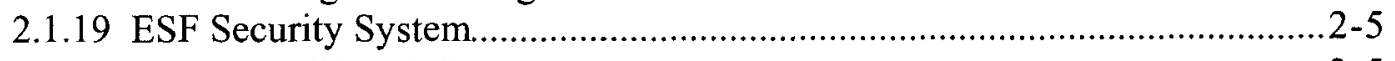

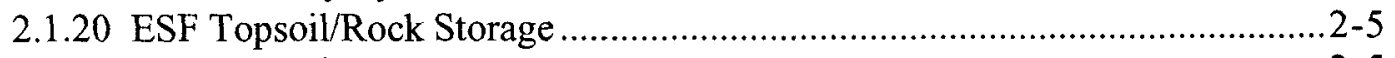

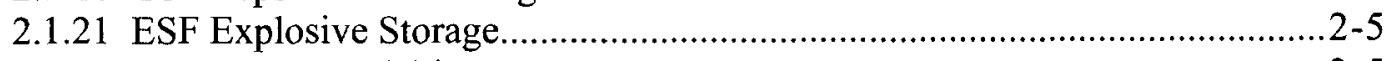

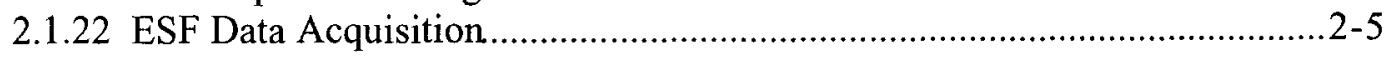

2.1.23 ESF Parking Areas............................................................................... 2-5

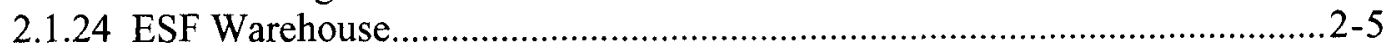

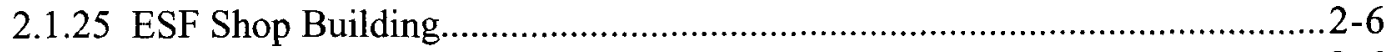

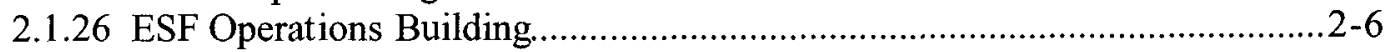

2.1.27 ESF Visitor Center............................................................................ 2-6

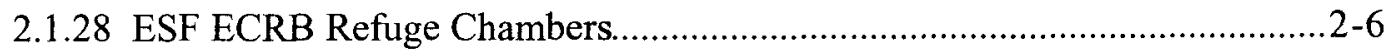

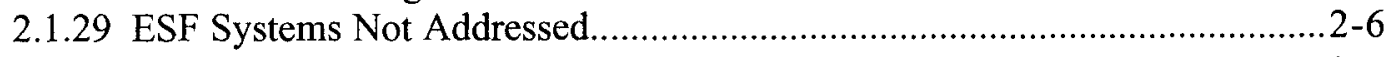

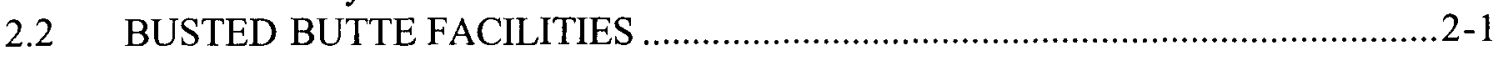

2.2.1 Busted Butte Subsurface Ventilation System ...........................................2-1

2.2.2 Busted Butte Power System.....................................................................2-7

2.2.3 Busted Butte Compressed Air System ........................................................2-7

2.2.4 Busted Butte Communication System ..................................................2-7 


\section{CONTENTS (Continued)}

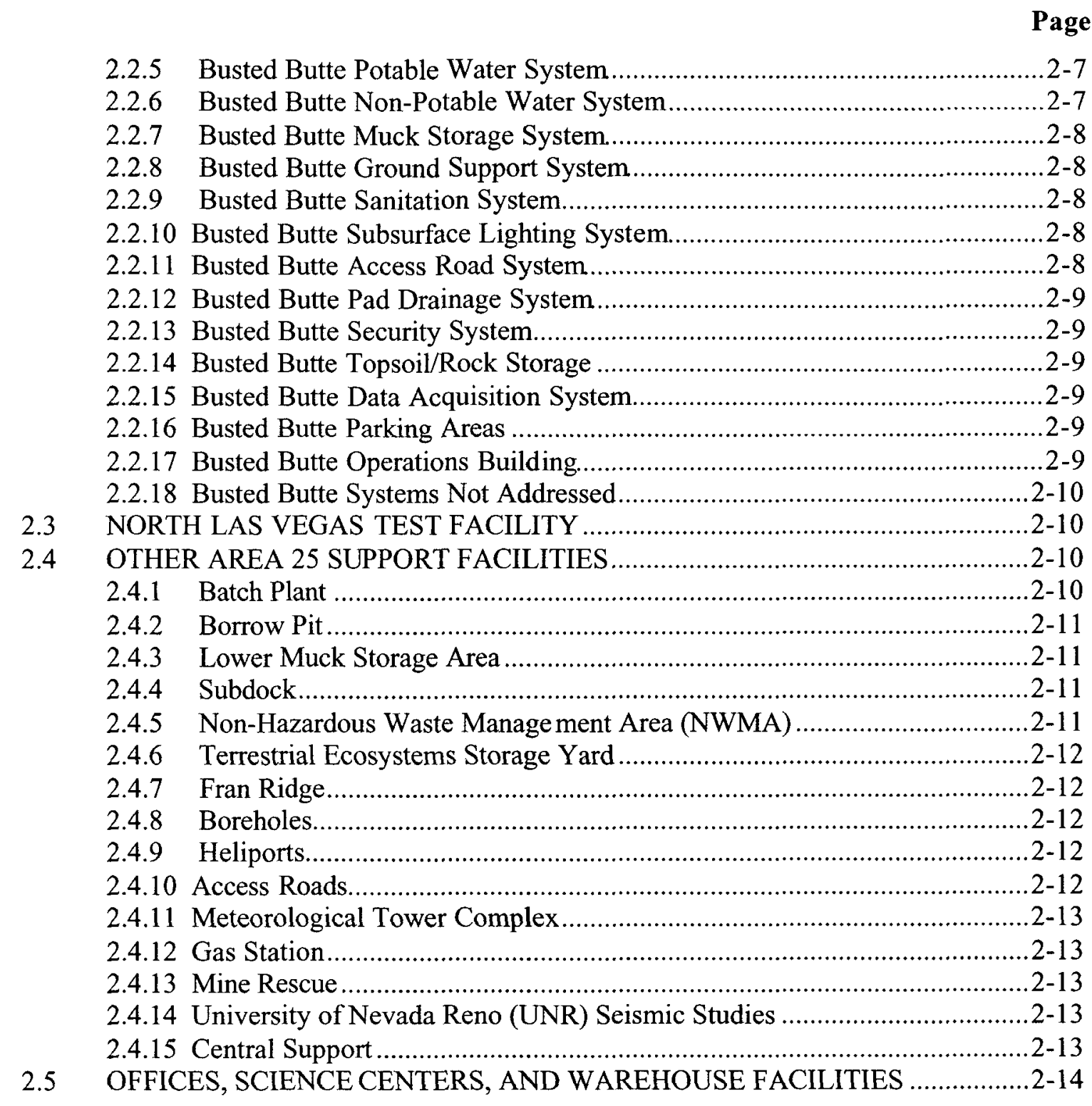

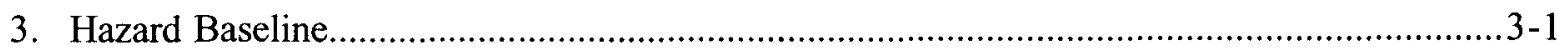

3.1 HAZARD BASELINE METHODOLOGY..................................................... 3-1

3.1.1 Radiological Inventory Assessment Methodology ........................................3-1

3.1.2 Chemical Inventory Assessment Methodology..............................................3-2

3.2 HIGH HAZARD CHEMICAL FACILITY …………......................................... 3-3

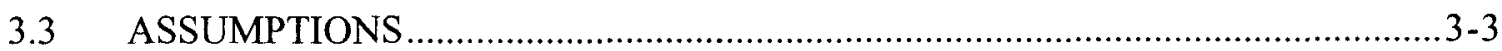

3.4 RADIOLOGICAL MATERIAL INVENTORY, ASSESSMENT, AND

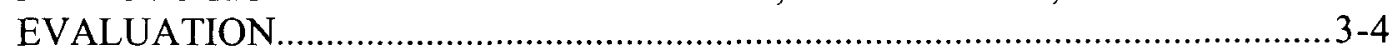

3.5 HAZARDOUS MATERIAL INVENTORY AND ASSESSMENT..........................3-4

3.6 CHEMICAL HAZARDS EVALUATION......................................................

3.7 HAZARD BASELINE DETERMINATION ………...........................................3-6

3.8 HAZARD BASELINE CONCLUSION ......................................................... 


\section{CONTENTS (Continued)}

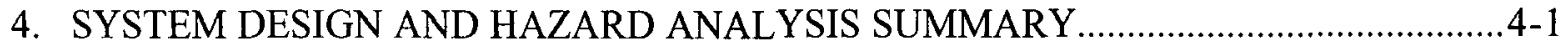

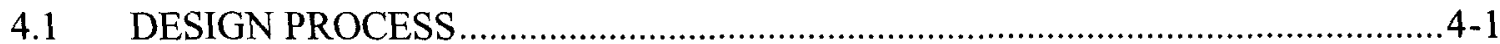

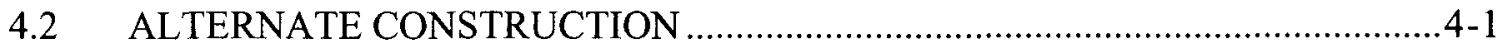

4.3 TITLE III EVALUATION REPORTS ….......................................................... $4-1$

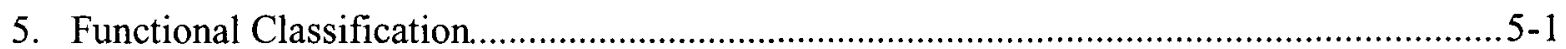

5.1 FUNCTIONAL CLASSIFICATION METHODOLOGY.................................. $5-1$

5.1.1 Functional Classification Criteria.........................................................5-1

5.1.2 Functional Classification Process........................................................... 5-3

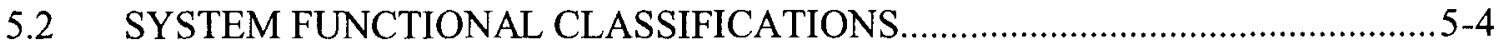

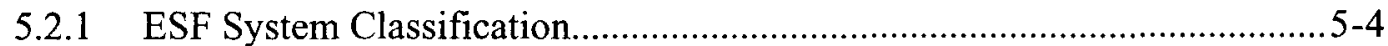

5.2.2 Busted Butte Facilities System Classifications ..........................................5-7

5.2.3 North Las Vegas Test Facility Classification............................................5-14

5.2.4 Other Area 25 Support Facilities........................................................5-15

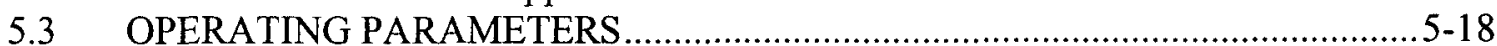

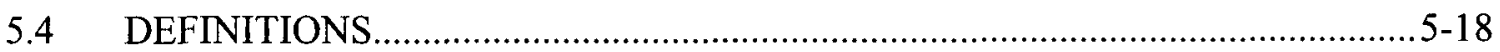

6. SAFETY BASIS MANAGEMENT

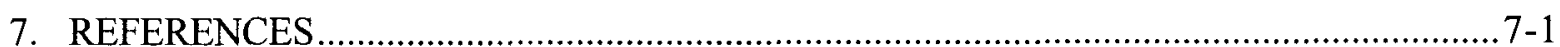

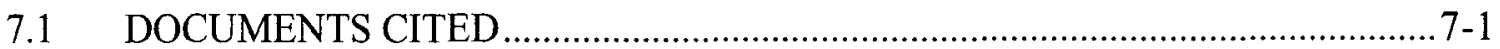

7.2 CODES, STANDARDS, AND PROCEDURES …............................................ $7-2$

APPENDIX A EVALUATION OF HAZARDOUS MATERIALS INVENTORIES ............. A-1 
INTENTIONALLY LEFT BLANK 


\section{FIGURES}

\section{TABLES}

5-1. Functional Classification of ESF Systems...............................................................

5-2. Functional Classification of Busted Butte Systems.................................................. 5-11

5-3. Functional Classification of North Las Vegas Test Facility Systems ..............................5-14

5-4. Functional Classification of the Other Area 25 Support Facility Systems .......................5-15

A-1. Comparison of Radiological Potentially Releasable Quantities from Unsealed Sources to DOE-STE-1027-92 Category 3 Radionuclide Thresholds............................ A-1

A-2. Comparison of Radiological Potentially Releasable Quantities from Unsealed Sources to 40 CFR 302.4 Appendix B Reportable Quantity Limits ............................ A-2

A-3. Comparison of ESF Chemical Inventory to Threshold Quantity and Threshold

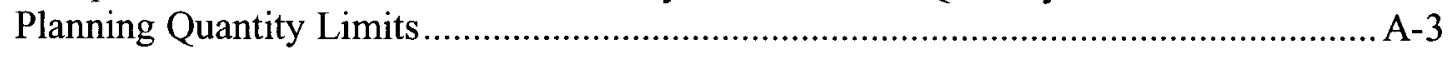

A-4. Comparison of North Las Vegas Test Facility Chemical Inventory to Threshold Quantity and Threshold Planning Quantity Limits................................................. A-16

A-5. Comparison of ESF Chemical Potentially Releasable Quantities to 40 CFR 302.4 Reportable Quantity Limits........................................................................ A-17

A-6. Comparison of North Las Vegas Test Facility Chemical Potentially Releasable Quantities to 40 CFR 302.4 Reportable Quantity Limits. 
INTENTIONALLY LEFT BLANK 


\section{ACRONYMS, SYMBOLS, AND UNITS}

\begin{tabular}{|c|c|}
\hline $\mathrm{A} / \mathrm{E}$ & Architect/Engineer \\
\hline $\mathrm{ACs}$ & Administrative Controls \\
\hline $\mathrm{BSC}$ & Bechtel SAIC Company \\
\hline CFR & Code of Federal Regulations \\
\hline DOE & U.S. Department of Energy \\
\hline ECRB & Enhanced Characterization of the Repository Block \\
\hline ERPG & Emergency Response Planning Guideline \\
\hline ESF & Exploratory Studies Facility \\
\hline ESFDR & Exploratory Studies Facility Design Requirements \\
\hline FCL & Functional Classification Level \\
\hline HRF & Hydrologic Research Facility \\
\hline $\mathrm{M \& O}$ & Management and Operating Contractor \\
\hline NTS & Nevada Test Site \\
\hline RF & Release Fraction \\
\hline RQ & Reportable Quantity \\
\hline SCSR & Self-Contained Self-Rescuer \\
\hline SSCs & Structures, Systems, and Components \\
\hline TBM & Tunnel-Boring Machine \\
\hline TPQs & Threshold Planning Quantities \\
\hline TQ & Threshold Quantity \\
\hline $\mathrm{TS}$ & Topopah Spring \\
\hline YMP & Yucca Mountain Site Characterization Project \\
\hline \multicolumn{2}{|c|}{ SYMBOLS AND UNITS } \\
\hline $\mathrm{Ci}$ & Curie \\
\hline $\mathrm{g}$ & gram \\
\hline gal & gallon \\
\hline $\mathrm{kg}$ & kilogram \\
\hline 1 & liter \\
\hline $\mathrm{lb}$ & pound \\
\hline $\mathrm{m}$ & meters \\
\hline $\mathrm{ml}$ & milliliter \\
\hline rem & Roentgen equivalent man \\
\hline $\mathrm{oz}$ & ounce \\
\hline psi & pounds per square inch \\
\hline
\end{tabular}




\section{SYMBOLS AND UNITS (Continued)}

$\begin{array}{ll}\text { pt } & \text { pint } \\ \text { qt } & \text { quart }\end{array}$


INTENTIONALLY LEFT BLANK 


\section{INTRODUCTION AND OVERVIEW}

As part of the internal Integrated Safety Management Assessment verification process, it was determined that there was a lack of documentation that summarizes the safety basis of the current Yucca Mountain Project (YMP) site characterization activities. It was noted that a safety basis would make it possible to establish a technically justifiable graded approach to the implementation of the requirements identified in the Standards/Requirements Identification Document. The Standards/Requirements Identification Documents commit a facility to compliance with specific requirements and, together with the hazard baseline documentation, provide a technical basis for ensuring that the public and workers are protected.

This Safety Basis Report has been developed to establish and document the safety basis of the current site characterization activities, establish and document the hazard baseline, and provide the technical basis for identifying structures, systems, and components (SSCs) that perform functions necessary to protect the public, the worker, and the environment from hazards unique to the YMP site characterization activities. This technical basis for identifying SSCs serves as a grading process for the implementation of programs such as Conduct of Operations (DOE Order 5480.19) and the Suspect/Counterfeit Items Program.

In addition, this report provides a consolidated summary of the hazards analyses processes developed to support the design, construction, and operation of the YMP site characterization facilities and, therefore, provides a tool for evaluating the safety impacts of changes to the design and operation of the YMP site characterization activities.

\subsection{ACTIVITY EVALUATION}

An activity evaluation was performed on the Integrated Safety Management System work scope to determine if this work is quality affecting. This activity evaluation (Gwyn 1999a) concluded that this activity is not quality affecting and is not subject to the requirements of Quality Assurance Requirements and Description (DOE 2000). As such, this report is classified as QA: NA.

\subsection{OVERVIEW}

Section 2 of this report identifies and describes the major systems of the YMP, including the Exploratory Studies Facilities (ESF), as well as the other Area 25 and off-site support facilities. This compilation will serve as the basis for the configuration of the YMP facilities and will be used for the Functional Classification activities described in Section 5. Some of the off-site support facilities utilize buildings that are privately owned, DOE or contractor leased facilities, which fall under the authority and permit of local governing agencies other than the DOE. It is the responsibility of the building owners to meet all local, state, and federal building codes and standards and the local authority to enforce those standards. When these buildings are used by the DOE or their contractors for the permitted purpose, these facilities will not be required to be functionally classified by this Safety Basis.

Section 3.0 develops the Facility Hazard Classification for all YMP facilities that support site characterization activities.. Using methodology established by the U.S. Department of Energy (DOE), the types of quantities of hazardous materials present at the Area 25 facilities were 
compared to applicable standards provided in various Codes of Federal Regulations. It was concluded that the YMP facilities that support the YMP site characterization activities are classified as Industrial Facilities. The hazardous materials assessed included hazardous chemicals and radioactive material in the form of sources used solely for calibration and testing radiation detectors and radiography.

Section 4 provides an overview of how the evaluation of hazards and the incorporation of safety considerations are an integral part of the design process. The alternate construction approach that was employed to expedite the completion of the ESF main drift tunnel is also described. Title III Evaluation Reports were developed to evaluate the appropriateness of further ESF modifications necessary to complete the ESF construction.

Functional Classification is the process for identifying functions (and the SSCs or Administrative Controls (ACs) that perform those functions) that reduce the risk to the public and workers from hazardous materials. Functional Classification is a graded classification system used to determine the minimum requirements for SSCs (i.e., requirements for design, operation, procurement, and maintenance). Four Functional Classification Levels (FCLs) and their corresponding criteria were developed and documented in Section 5. These classifications provide a clear distinction between the ESF systems that support the mitigation of hazards that are unique to the YMP site characterization activities and those YMP systems that mitigate hazards that are common to the tunneling industry. This distinction is important because the hazards that are common to the tunneling industry (for Area 25 activities) are well known and have been characterized. National consensus standards and codes have been established to address the mitigation of these common hazards. The hazards that are unique to the YMP site characterization activities have to be specifically addressed and analyzed as there are no available codes and standards to address these unique hazards. The Functional Classification of the 29 ESF systems described in Section 2 resulted in all systems being classified as FCL3 or FCL4 (important to sustaining production but not involved with mitigating a unique YMP site characterization hazard).

The management and control of changes to this report is provided for and described in Section 6. The Management of Safety Basis Change Process procedure (AP-ENG-001) was produced to provide the appropriate guidance and controls for managing changes to the safety basis for the YMP site characterization activities.

\subsection{SUMMARY}

The hazard baseline and the Functional Classification of the systems that comprise the YMP have been established and documented in this report. The hazard baseline analysis resulted in the classification of the YMP site characterization facilities as an Industrial Facility. The Functional Classification documented the functions of the systems that comprise the YMP to reduce the risk to the public and workers from YMP activities and hazardous materials. All YMP systems were classified as FCL3 or FCL4. 


\section{YMP FACILITIES}

The facilities that support current YMP activities include numerous test areas and facilities in Area 25 of the Nevada Test Site (NTS) as well as office buildings, a warehouse, science centers, and laboratory test facilities in Las Vegas and other locations, both in-state and out-of-state. This section provides a brief description of these YMP facilities for the purpose of describing the roles of these facilities and the hazards associated with them to establish a comprehensive safety basis. The ESF has been organized into systems that are consistent with the Exploratory Studies Facility Design Requirements (ESFDR) (YMP 1997). The FCLs of the YMP systems are established in Section 5.

\section{$2.1 \quad$ ESF SYSTEMS}

\subsubsection{ESF Subsurface Ventilation System}

The Subsurface Ventilation System provides fresh air to the ESF subsurface using three main ventilation systems consisting of fans and ductwork. The Topopah Spring (TS) Loop is ventilated using a flow-through system in which air is drawn through the tunnel from the North to the South Portal using fans and a ventilation bulkhead located near the South Portal. The Cross Drift is ventilated using an exhaust system that removes the air from the terminal end of the Cross Drift and exhausts it at the North Portal. The ESF alcoves are ventilated either by reusing the air from the bored tunnel (TS Loop or Cross Drift) or by means of an exhaust system that transports the air to the North Portal. Standby power is provided to the flow-through system by the generator located on the South Portal Pad.

\subsubsection{ESF Conveyor System}

The Conveyor System provides a means of transporting muck from the subsurface using a rubber belt conveyor controlled through the Programmable Logic Controller system. The 36-inch wide TS Loop section consists of the Radial Stacker, Transfer Tower No. 1, belt take-up and storage unit, booster and return booster drives, conveyor supports and accessories, automatic water sprays, and a tail pulley that is moved to suit the needs of construction. The similar 24-inch wide Cross Drift section connects with the TS Loop section at the Cross Drift Conveyor Transfer Point.

\subsubsection{ESF Power System}

ESF Surface Power System-The Surface Power System extends from 8 feet north of the 25-16 Substation Fence to the Subsurface Power Center and includes:

- Pad mounted distribution transformers

- Medium voltage (12,470 and 4,160 volts) distribution systems 
- Distribution to permanent facilities, an air compressor system, and the buried distribution system

- Lightning protection and grounding

The Surface Power System also distributes power to the DOE-owned structures that were originally supplied and constructed by the previous tunneling contractor as "constructorfurnished temporary facilities."

ESF Subsurface Power System-The Subsurface Power System includes the Subsurface Power Center, North Portal and south standby generator systems, flow-through ventilation system, Alcove \#5 power distribution system, and the Cross Drift power distribution system. The Subsurface Power System also includes the constructor-furnished power distribution systems including the 12,470 medium volt distribution system, low voltage (480 and 120/208 volts) distribution systems, mine power centers and equipment, and subsurface grounding.

\subsubsection{ESF Compressed Air System}

The Compressed Air System provides a means of supplying pressurized air to the surface and subsurface for use in construction operations. The system consists of two air compressors (one primary and one backup) located on the North Portal Pad and piping and accessories that traverse both the TS Loop and the Cross Drift.

\subsubsection{ESF Waste Water System}

The Waste Water System provides a means of transporting water used in mining or drilling operations in the TS Loop and Cross Drift to surface storage tanks. The system consists of three surface tanks (two settling and one storage) located on the North Portal Pad, piping and accessories that traverse the TS Loop and the Cross Drift, sumps, pumps, and a settling tank located at the Cross Drift starter tunnel. Stored water is used for dust control on the North Portal Pad.

\subsubsection{ESF Material and Personnel Handling System}

The Material and Personnel Handling System provides a means to transport people, equipment, materials, or muck to and from the subsurface areas to meet the needs of construction and testing. The system includes rail cars, locomotives, rail and accessories, and the concrete invert segments. The TS Loop rail system consists of rebar ties placed in the concrete invert segment blockouts and attached to rails set at 36-inch gage. The Cross Drift rail system consists of 36-inch gage rail attached to wood ties that have been coated with fire retardant paint.

\subsubsection{ESF Communication System}

The Communication System provides a means of linking the surface and subsurface areas, facilities, and outside commercial communication systems. The surface system consists of a telephone link through the microwave system, a radio link with NTS, fiber optic lines for 
computer use, and a link to the subsurface mine phones. The TS Loop and Cross Drift use Femco mine phones as the primary means of communication.

\subsubsection{ESF Potable Water System}

The Potable Water System provides chlorinated water to the North Portal Pad. The system consists of a 50,000-gallon tank, a chlorination shed, and piping and accessories. Water is pumped from the Booster Pump Station into the tank, is chlorinated, and then gravity fed through the buried North Portal Pad piping.

\subsubsection{ESF Non-Potable Water System}

ESF Surface Non-Potable Water System-The Surface Non-Potable Water System provides water to the North Portal Pad for use in construction operations and fire protection. The system consists of a 200,000-gallon tank, piping and accessories, and fire hydrants. Water is pumped from well J-13 through the Booster Pump Station into the tank, and is then gravity fed through the buried North Portal Pad piping.

ESF Subsurface Fire Water System and Subsurface Portion of the Non-Potable Water System-The Subsurface Fire Water System and subsurface portion of the Non-Potable Water System transfers water from the Surface Non-Potable Water System to the subsurface for use in construction operations and fire suppression. The system consists of three tanks and transfer pumps located on the North Portal Pad, piping and accessories that traverse the TS Loop and Cross Drift, fire hose stations, and portable fire extinguishers. Water is manually mixed with a lithium bromide tracer in the holding tanks prior to being introduced to the subsurface areas. In the event of a large fire that requires the volume of all three tanks, additional fire water could be drawn from the Surface Non-Potable Water System; however, there would not be sufficient time to add lithium bromide tracer prior to adding the water to the system. This is unlikely because the Subsurface Fire Water System is only used as backup means of fighting incipient fires.

\subsubsection{ESF Muck Storage System}

The Muck Storage System provides an area for the storage of excavated rock from subsurface construction. The storage pile is located east of the North Portal Pad and west of the North Portal Pad road. Muck that is piled from the end of the Radial Stacker is transferred to the storage pile using mechanical equipment.

\subsubsection{ESF Ground Support System}

The Ground Support System provides a means of structural support or reinforcement to the rock of excavated openings and protection to personnel and equipment against falls of ground within the excavated openings. The system consists of various types of rock bolts used in conjunction with welded wire fabric, mine mats, and shotcrete, and steel sets used in conjunction with lagging and cribbing.

ESF Q Ground Support-Q ground support includes the ground support installed in the North Ramp Starter Tunnel, Alcove \#1, TS Loop, Cross Drift Starter Tunnel and transition zone, TS Loop alcove and niche transition zones, and the South Portal headwall. 
ESF Non-Q Ground Support-Non-Q ground support includes the ground support installed from the end of the transition zone to the face of the terminal end of TS Loop alcoves and niches and the Cross Drift, Cross Drift alcoves and niches, the North Portal head wall and sidewalls, and the South Portal side walls.

\subsubsection{ESF Sanitation System}

The Sanitation System provides a means of collecting and transporting sanitary waste from the North Portal Pad facilities to the treatment system, and from the subsurface to the surface.

ESF Surface Sanitation System-The Surface Sanitation System consists of a buried collection system consisting of piping and manholes and a buried treatment system consisting of a septic tank, dosing tank, distribution boxes, and a leach field.

ESF Subsurface Sanitation System-The Subsurface Sanitation System consists of portable toilets located throughout the TS Loop and Cross Drift. The portable toilets are maintained by utilizing the Sanitation Car, which is then emptied periodically by the NTS contractor.

\subsubsection{ESF Subsurface Lighting System}

The Subsurface Lighting System provides illumination to subsurface areas including the TS Loop and the Cross Drift, alcoves, niches, and portal entrances. The system consists of light fixtures, wiring, portable light fixtures, and exit and emergency lighting.

\subsubsection{ESF Access Road System}

The Access Road System provides a link connecting the North Portal Pad to auxiliary sites and to the NTS road system. The system includes the North and South Portal access roads and the Muck Storage, Topsoil and Rock Storage, and Water Storage access roads.

\subsubsection{ESF North Portal Pad Drainage System}

The North Portal Pad Drainage System provides a means to divert and transport storm water runoff on the North Portal Pad. The system consists of an interceptor channel, a drainage interceptor ditch, road drainage ditches, and culverts that discharge to retrieval channels.

\subsubsection{ESF South Portal Pad Drainage}

The South Portal Pad slopes away from the portal, thereby prohibiting storm water runoff from entering the tunnel.

\subsubsection{ESF Change House}

The Change House is a permanent building located on the North Portal Pad that provides a structure that houses shower and locker facilities for personnel, medical and training facilities, and mine rescue facilities. The ESF Change House is also used by Busted Butte personnel at the beginning and end of shift for more significant change house functions other than the simple change house functions conducted at trailers at the Busted Butte site. 


\subsubsection{ESF Switchgear Building}

The Switchgear Building is a permanent building located on the North Portal Pad that provides an enclosure for electrical switchgear equipment and ice-making equipment.

\subsubsection{ESF Security System}

The Security System provides protection to the ESF facilities and controls access to the North and South Portals. The system consists of barbed wire fencing around the perimeter of the North Portal Pad, and chain link fencing and gates located at the North and South Portals, the main entrances to the North and South Portal Pads, and the entry to the Muck Storage area. Underground access to both the North and South Portals is controlled by trained personnel at the Access Control Station located near the North Portal.

\subsubsection{ESF Topsoil/Rock Storage}

The Topsoil/Rock Storage Area is located in Area 25 of the NTS, midway between the North and South Portal Pads. Topsoil removed during the construction of the ESF North Portal Pad is stored in this area. The stored soil is contoured to prevent erosion and excess runoff, and stabilized by the presence of plants and grasses introduced by the Environmental Sciences Section. No structures, services, or utilities are present.

\subsubsection{ESF Explosive Storage}

Explosive Storage for the ESF provides a locked facility for explosives used in tunneling operations. The system consists of two International Society of Mechanical Engineers Type II magazines, one for powder and one for blasting caps, located in Split Wash. Explosives are transported underground utilizing a special-use Explosive Car.

\subsubsection{ESF Data Acquisition}

Data Acquisition provides a means for the Test Coordination Office to collect data from testing equipment throughout the ESF underground, including the Data Collection System for the Drift Scale Test. Data is collected both manually and using a real-time data collection network via fiber optic lines. Standby power is provided to the Data Collection System by the generator located on the North Portal Pad.

\subsubsection{ESF Parking Areas}

Parking Areas provide spaces and allowances for vehicle parking necessary to support operations and testing.

\subsubsection{ESF Warehouse}

The Warehouse provides enclosures for the storage of construction materials. The two DOEowned, fabric type, pre-engineered structures are located on the North Portal Pad and were originally supplied and constructed by the previous tunneling contractor as "constructor furnished temporary facilities." 


\subsubsection{ESF Shop Building}

The Shop Building provides a series of structures for the maintenance and repair of equipment used in construction and operations. The DOE-owned Conex complex is located on the North Portal Pad and was originally supplied and constructed by the previous tunneling contractor as "constructor furnished temporary facilities."

\subsubsection{ESF Operations Building}

The Operations Building provides office structures that support ESF personnel. The DOEowned temporary trailers are located on the North Portal Pad and were originally supplied and constructed by the previous tunneling contractor as "constructor furnished temporary facilities."

\subsubsection{ESF Visitor Center}

The ESF Visitor Center provides information and staging areas for public tours to the ESF. Current visitor presentations are conducted in the Change House and in Alcove $\# 2$.

\subsubsection{ESF ECRB Refuge Chambers}

Refuge chambers are located in the ECRB to provide a method of refuge for employees or visitors who cannot reach the surface using the normal exit method in the event of a hazard such as a fire. Two refuge chambers are located in the ECRB cross drift: one at Alcove 8; the other behind the bulkhead at Station $17+63$ at the page phone at Station $18+43$ (BSC 2001a). Both refuge chambers are constructed so that they can be made gas-tight, have compressed air lines, water lines, and mine phones behind the ir respective bulkheads, and have firestopping material applied to the ir respective bulkheads. Each refuge chamber contains bottled water, gas detectors, and other assorted tools and miscellaneous equipment (e.g., blankets, toilets, flashlights). Materials and equipment are also provided for sealing the chambers, included duct tape, buckets, quick setting cementitous compound, and ladders. The refuge chamber behind the bulkhead at Station $17+63$ at the page phone at Station $18+43$ is supplied with half-face respirators. The refuge chamber at Alcove 8 is equipped with supplied-air full face respirators and demand regulators attached to compressed air bottles as well as self-contained self-rescuers (BSC 2001b). The maximum number of miners, visitors, and support personnel in the ECRB is limited to 30 due to the fact that there are 30 bottles of compressed air stored in the refuge chamber at Alcove 8 (BSC 2001c). However, based on the space requirements in the refuge chamber at Alcove 8 , a maximum of 53 individuals may be allowed in the ECRB if the number of air bottles in the refuge chamber is increased to 53 (BSC 2001b).

\subsubsection{ESF Systems Not Addressed}

The following systems discussed in the ESFDR (YMP 1997) are not addressed since they are not present in the current ESF configuration: Covered Storage, Guard House, Surface Conveyor System, Load Management System, Facility Monitoring and Control System, and Subsurface Monitoring and Warning System. 


\subsection{BUSTED BUTTE FACILITIES}

The Busted Butte Test Facility was constructed to conduct the Unsaturated Zone (UZ) Transport Test, which is part of the overall program of site characterization at Yucca Mountain. The facility is located at Busted Butte in Area 25 of the NTS, approximately 5 miles southeast of the ESF. The facility is comprised of a dirt road from Stagecoach Road, a rock highwall and pad, and an underground testing facility consisting of a nominally $60-\mathrm{m}$ adit and $15-\mathrm{m}$ test alcove. The facility was built to conduct transport testing in the Calico Hills rock section that outcrops at Busted Butte.

Test management, coordination, and implementation is conducted using Field Work Package FWP-ESF-96-002 (CRWMS M\&O 1999), which was written, approved, and revised according to AP-5.2Q, Testing Work Packages. Hazard identification and mitigation for the test operations within this facility are conducted in accordance with AP-ESH-008, Hazard Analysis System, or equivalent process in place when FWP-ESF-96-002 was last revised.

The Busted Butte Test Facility, as currently constructed, is comprised of the systems described in the following subsections. The FCLs of these systems are established in Section 5.3.

\subsubsection{Busted Butte Subsurface Ventilation System}

The Busted Butte Subsurface Ventilation System provides fresh air to the subsurface using a single ventilation system, consisting of a $30 \mathrm{hp}$ exhaust fan and 36-inch diameter ventline 
system, capable of generating $35,000 \mathrm{cfm}$. Ventilation is established by using a pull system in which outside air is pulled through the portal to the end of the ducts located near the end of the main adit, and a split located in the test alcove. The air is exhausted through a duct running up from the portal to an area above the highwall. Ventilation is supplied underground only when personnel are working underground to minimize drying out of the test bed. All power is supplied by one of two generators located on the Busted Butte Pad.

\subsubsection{Busted Butte Power System}

All power at Busted Butte is supplied by one of two diesel generators located on the Busted Butte Pad. Each generator generates about $125 \mathrm{~kW}$. Power is necessary 24 hours per day, 7 days per week for scientific activities. Standby power is provided to the facility by a backup generator. The generators are wired to provide 480 volts. The surface power requirements include low voltage (120/208 volts) distribution systems mainly to power two surface trailers, one for the constructor and one for scientific activities. The subsurface power requirements include low voltage (480 and 120/208 volts) distribution systems for construction and testing activities, and subsurface grounding.

\subsubsection{Busted Butte Compressed Air System}

The Busted Butte Compressed Air System provides a means of supplying pressurized air to the surface and subsurface for use mainly in construction operations. The system consists of a single, diesel air compressor located on the Busted Butte Pad, and piping and accessories that traverse into the underground facilities. The air compressor generates $175 \mathrm{cfm}$, and is used infrequently.

\subsubsection{Busted Butte Communication System}

The Busted Butte Communication System provides a means of linking the surface and subsurface areas, facilities, and outside commercial telephone communication systems. The surface system consists of a telephone link through the microwave system, a radio link with NTS, lines for computer use, and a link to the subsurface mine phones and telephone.

\subsubsection{Busted Butte Potable Water System}

Potable water is supplied to Busted Butte using five-gallon water bottles.

\subsubsection{Busted Butte Non-Potable Water System}

The Busted Butte Non-Potable Water System provides a means of storing water used in mining or drilling operations at Busted Butte in a surface storage tank. The system consists of a single surface tank located on the Busted Butte Pad, and piping and accessories that traverse into the underground facilities. Water is pumped from well $\mathrm{J}-13$ into trucks, transported to the Busted Butte Pad and pumped into the surface storage tank, and is then gravity fed or pumped to the underground facility.

Busted Butte Surface Non-Potable Water System-The Busted Butte Surface Non-Potable Water System provides water to the Busted Butte Pad for use in construction operations and fire 
protection. The system consists of a surface storage tank, piping and accessories, and portable fire extinguishers.

Busted Butte Subsurface Fire Water System and Subsurface Portion of the Non-Potable Water System-The Busted Butte Subsurface Fire Water System and subsurface portion of the Non-Potable Water System transfers water from the Surface Non-Potable Water System to the subsurface for use in construction operations and fire suppression. The system consists of the surface storage tank, piping and accessories that traverse into the underground facility, and portable fire extinguishers.

\subsubsection{Busted Butte Muck Storage System}

The Busted Butte Muck Storage System area provides an area for the storage of excavated rock from subsurface construction. The storage area is located at the southeast edge of the Busted Butte Pad, where muck is dumped over the edge of the pad. Muck is transported and dumped using diesel front-end loaders. Only small amounts of muck have been generated since the construction of the facility in early FY 1998. This muck was generated from a Phase 1 partialmineback in FY 1999. Small amounts of muck will be generated for planned Phase 2 partialminebacks during FY 2001.

\subsubsection{Busted Butte Ground Support System}

The Busted Butte Ground Support System provides a means of structural support or reinforcement to the rock of excavated openings and protection to personnel and equipment against falls of ground within the excavated openings. The system consists of various types of rock bolts used in conjunction with welded wire fabric, rebar (up to 1 inch diameter), and shotcrete. Shotcrete pillars were used on the ribs for additional stability. Shotcrete pillars reinforced with rebar (1-inch diameter) were used at the intersection of the main adit and the test alcove for additional stability. An analysis was conducted by architect/engineer (A/E) Title II design that confirmed the safety of the ground support system. There is no "Q" ground support in the Busted Butte facility.

\subsubsection{Busted Butte Sanitation System}

The Sanitation System at Busted Butte consists of a portable toilet located on the surface. The portable toilet is maintained by utilizing a sanitation pump truck.

\subsubsection{Busted Butte Subsurface Lighting System}

The Busted Butte Subsurface Lighting System provides illumination to subsurface areas including the main adit and test alcove. The system at Busted Butte consists of light fixtures, wiring, portable light fixtures, and exit and emergency lighting.

\subsubsection{Busted Butte Access Road System}

The Busted Butte Access Road System provides a link connecting the Busted Butte Test Facility to the NTS and the Area 25 road system. The system includes the J13 road (that connects to Stagecoach road through 40-Mile Wash) that connects to the Busted Butte access road. This 
road system was constructed in early FY 1998 specifically for access to Busted Butte. Road J13 connects to H-Road, a main, paved road in Area 25.

\subsubsection{Busted Butte Pad Drainage System}

The Busted Butte Pad Drainage System is a simple gravity system that provides a means to divert and transport storm water runoff on the Busted Butte Pad. The pad was designed to slope away from the portal, thereby prohibiting storm water runoff from entering the tunnel or ponding on the pad area.

\subsubsection{Busted Butte Security System}

The Security System at Busted Butte consists of two locked gates, one across the access road leading to the Busted Butte Pad; the other closing off the portal. These gates control access to the facility and provide protection to the Busted Butte facilities. Underground access during working hours is controlled by working personnel at the facility. No access is allowed without coordination with the site person in charge.

\subsubsection{Busted Butte Topsoil/Rock Storage}

Busted Butte Topsoil/Rock Storage for the access road consists of a berm located along the road. The berm was leveled and seeded to be wind resistant, and provides the original topsoil for covering the road during final remediation of the Busted Butte facility. The muck storage area at the Busted Butte Pad provides the area for placement of excavated materials from underground, as discussed previously.

\subsubsection{Busted Butte Data Acquisition System}

The Busted Butte Data Acquisition System provides a means for the Principal Investigator organization and Test Coordination Office to collect data from testing equipment located underground at Busted Butte. Data is collected manually, automatically, and using a real-time data collection network via telephone. Using the real-time system, data can be collected by scientists located in Santa Fe and Los Alamos, New Mexico. An extensive Uninterruptible Power Supply system provides up to several days of power backup in case of power interruption. Standby power is provided to the Data Collection System by one of two generators located on the Busted Butte Pad.

\subsubsection{Busted Butte Parking Areas}

Busted Butte Parking Areas provide spaces and allowances for vehicle parking necessary to support operations and testing. There are parking areas on the main Busted Butte Pad near the trailers, and at a satellite pad on the access road located just down the hill from the main pad.

\subsubsection{Busted Butte Operations Building}

There are trailers on the Busted Butte Pad that provide office structures that support Busted Butte personnel. Personnel also use ESF operations buildings that are DOE-owned temporary trailers located on the North Portal Pad. 


\subsubsection{Busted Butte Systems Not Addressed}

The following systems discussed in the ESFDR (YMP 1997) are not addressed since they are not present in the current Busted Butte configuration: Covered Storage, Guard House, Surface Conveyor System, Load Management System, Facility Monitoring and Control System, and Subsurface Monitoring and Warning System. In addition, unlike the ESF, there is no Conveyor System, Waste Water System, Material and Personnel Handling System, Switchgear Building, Change House, Explosive Storage, Warehouse, Shop Building, or Visitors Center.

\subsection{NORTH LAS VEGAS TEST FACILITY}

The YMP currently occupies two buildings within the North Las Vegas Facility, also known as the "Atlas" facilities, to conduct testing. The buildings are leased and permitted through DOE from Bechtel Nevada and all facilities are built and maintained according to state and local codes and regulations. Any modifications to infrastructure or facility conditions are made through the Bechtel Nevada contract.

The testing being conducted in these buildings is related to the Engineered Barrier Systems and Waste Package studies. Specifically, this testing involves:

- Soil properties testing in a laboratory environment

- A small scale thermal-hydrological-chemical test

- Scale thermal tests on various drip shield and backfill concepts

- A 40-m long thermal/ventilation experiment

All testing activities are routine and comparable to activities conducted at the ESF; they pose no extraordinary or unusual potential hazards beyond what is inherent to the baseline field-testing program.

\subsection{OTHER AREA 25 SUPPORT FACILITIES}

\subsubsection{Batch Plant}

The batch plant and the associated casting plant are located in Area 25 of the NTS, south of Hroad and approximately one-half mile east of Forty Mile Wash. The plant provides batch concrete for foundations and pours needed by the ESF, and supplies concrete to the casting yard to the west. Inverts for the main ESF drift were cast in the yard. The batch plant is a standard industry configuration consisting of storage bins, tanks, hoppers, conveyors, and system controls needed to dry batch concrete for truck delivery. Additionally, the plant includes a chiller system, ice storage, and testing laboratory. The casting yard includes invert molds, a steam plant, rebar process area, casting bed, steam lines, tanks, and various office buildings. Water and power are provided to the plant and the yard to support the processes only. Drinking water is provided in jugs and portable toilet facilities are located nearby. Currently, these facilities are closed and access is controlled. 


\subsubsection{Borrow Pit}

The borrow pit is located in Area 25 of the NTS, west of H-Road and approximately one-half mile in a northerly direction from the H-Road crossing of Forty Mile Wash. The borrow pit is the source of all Project aggregate. The borrow pit is a standard aggregate production operation in keeping with industrial practice. Facilities present consist of a shaker plant, sizing screens, and a stockpile conveyor. A diesel generator provides power and dust control water is drawn from an on-site tank. No outside service or utilities are available. Drinking water is provided in jugs and portable toilet facilities are located nearby.

\subsubsection{Lower Muck Storage Area}

The lower muck storage area is located in Area 25 of the NTS, north of H-Road and approximately one-half mile southeast of the ESF Pad. Muck has never been stored at the Lower Muck Storage Area. This storage area is for the accumulation of materials, supplies, and equipment not currently in use at the ESF. Items no longer in use are to be sold or transferred to other agencies as excess. A limited number of transportainers and boxcars are present and being utilized for protected storage. No services or utilities are present.

\subsubsection{Subdock}

The Subdock is located in Area 25 of the NTS, along the south side of H-Road and approximately one mile west of the turnoff to the ESF North Portal Pad. This area is used for the accumulation of drilling related materials, supplies, and equipment (tanks, drill rigs, tubing, generators, fuel tanks, etc.) not currently in use at the ESF. Items no longer in use are to be sold or transferred to other agencies as excess. A limited number of transportainers and boxcars are present and are utilized for protected storage. An office, a shop, and craft locker room transportainers are also present. A diesel generator provides power to the shop, office, and other buildings as needed. No outside service or utilities are available. Drinking water is provided in jugs and portable toilet facilities are located nearby.

\subsubsection{Non-Hazardous Waste Management Area (NWMA)}

The NWMA is located in Area 25 of the NTS, on the north side of H-Road and approximately one and one-quarter miles west of the turnoff to the ESF North Portal Pad. The NWMA is the collection and off-site shipment facility for non-hazardous wastes, including waste petroleum hydrocarbons, used batteries, oily rags, and oil contaminated soil. The area also houses the oily water skimming system and the supply of barrels and tanks used to collect and store the various wastes. The wastes are contained within a fenced area and all fluid wastes are placed in secondary containment. Office/field lab transportainer and materials storage boxcars are adjacent to the fenced area. Line power is provided to the office/field lab and yard. No water is piped to the yard. Drinking water is provided in jugs and portable toilet facilities are located nearby. 


\subsubsection{Terrestrial Ecosystems Storage Yard}

The terrestrial ecosystem (i.e., environmental) storage yard is located in Area 25 of the NTS, on the north side of H-Road and approximately one and one-half miles west of the turnoff to the ESF North Portal Pad. This storage yard houses the reclamation materials, supplies, and equipment used to re-seed areas disturbed by testing, construction, and operations once they are no longer needed. Various farm implements, an office trailer, storage boxcar, and hay storage are located at this site. Line power is provided to the office trailer. No water is piped to the yard. Drinking water is provided in jugs and portable toilet facilities are located nearby.

\subsubsection{Fran Ridge}

Fran Ridge is the site of the large block test performed by Los Alamos National Laboratory. It is located in Area 25 of the NTS, west of the Yucca Crest road and approximately one and threequarter miles southwest of the H-Road and Yucca Crest Road intersection. This facility is closed with no current plans for reactivation.

\subsubsection{Boreholes}

Yucca Mountain Project boreholes are located primarily in Area 25 and at various locations on and off the NTS. More than, approximately, 350 YMP boreholes exist. The general configuration at each borehole site includes a pad and a capped and secured casing stickup. These boreholes are used for below ground testing. No outside service or utilities are available. Instrument shelters are present at four borehole sites. When active, a shelter is powered by a diesel-fueled generator. The generators and their fuel tanks are located within containment. All borehole sites are visited on a set schedule to assess their condition and security.

\subsubsection{Heliports}

Two heliports are currently available for YMP use in Area 25 of the NTS: the Central Support Area and ESF Pad Heliports. The Central Support Area Pad Heliport is available for emergency medical service landings and guest helicopter visits. The ESF Pad Heliport is located east of the northern half of the North Portal Pad. The landing pad is a concrete slab approximately 100 feet by 100 feet. A wheel-mounted fire extinguisher is present for emergencies. The ESF Pad Heliport is available for emergency medical service landings and guest helicopter visits. No outside service or utilities are available. The Central Support Area heliport is located west of Second Street between "A" and "B" streets. The landing pad is an asphalt slab approximately 100 feet by 100 feet. A wheel-mounted fire extinguisher is present for emergencies.

\subsubsection{Access Roads}

The YMP access roads within the YMP site (i.e., the Ranch Area) are located within Area 25 of the NTS, primarily west of Forty Mile Wash. These roads consist of the paved $\mathrm{H}$-road which provides primary access to the ESF; two short, paved extensions leading from H-Road to the North and South Portal Pads; and various unimproved dirt and gravel roads that provide access to the boreholes and surface testing locations. These roads are the primary routes of access for the performance of surface site characterization and underground facilities. One concrete low- 
water crossing section is provided in Forty Mile Wash. The low-water crossing section is provided to resist erosion and destruction of the road surface in the wash during winter flooding. No services or utilities are involved.

\subsubsection{Meteorological Tower Complex}

The meteorological tower complex is located in Area 25 of the NTS, one-half mile southeast of the H-Road, South Portal road turnoff. This facility supports the meteorological monitoring and data collection activities for the YMP site. Several trailers and an instrument shelter are located on-site. Line power is provided to the site. No other utilities are provided. Drinking water is provided in jugs and portable toilet facilities are located nearby.

\subsubsection{Gas Station}

The gas station is located in Area 25 of the NTS, Central Support Area, at the corner of Second and "E" streets. This facility provides fuel for the YMP on-site vehicles. The site consists of a gas station building (Bldg. 4838), a 10,000-gallon, above-ground fuel tank, gasoline dispensing system, and various service aprons. With the exception of a small, northeast corner office housing data relay equipment, the building is not utilized by the YMP. Line power is provided to the facility and water is available for vehicle needs. No sanitary facility is available. A spill kit is located near the outside, southeast corner of the building, with an emergency phone at the outside, northeast building corner. A spill plan and operating procedures are in place for the above-ground tank.

\subsubsection{Mine Rescue}

The Mine Rescue Facility is located in Area 25 of the NTS, Central Support Area, at the corner of Third and "C" streets. The facility includes a single building (Bldg. 4919) and fenced storage yard. This facility is used for the maintenance and storage of YMP mine rescue equipment and the training of mine rescue personnel. All available services and utilities (water, power, and sanitation) are provided. A secondary, alternate mine rescue equipment storage and staging area is provided in the ESF Change House (Bldg. 5008).

\subsubsection{University of Nevada Reno (UNR) Seismic Studies}

The UNR seismic studies facility is located in Area 25 of the NTS, Central Support Area, on "D" street between Second and First streets. The facility includes a single building (Bldg. 4314) and fenced storage yard. This facility is used for the maintenance and storage of UNR seismic monitoring equipment and supplies. Occupancy by UNR personnel is sporadic. All available services and utilities (water, power, and sanitation) are provided.

\subsubsection{Central Support}

The Central Support area is comprised of the Sample Management Facility, the Hydrologic Research Facility (HRF), and the Site Maintenance Building, as described in the following paragraphs. 
Sample Management Facility - The Sample Management Facility is located at the Central Support Area within Area 25. The mission of the Sample Management Facility is to provide a controlled location to archive geologic and hydrologic samples that have been collected under the appropriate YMP quality procedures and to provide a location to manipulate (cut, shape, and/or polish) the samples. The facility consists of two buildings. The main building consists of office areas, sample examinations areas, warehouse area, two refrigerated walk-in coolers, and an area for conducting lapidary operations. The second building is equipped for sample storage in a warehouse area as well as a small area for storing consumables, (i.e., extra plastic and or canvas sample collection bags, tape, and other sample packaging materials). Both facilities are centrally heated and cooled and equipped with potable water for the drinking fountains and the toilet facilities.

Hydrologic Research Facility-The HRF is a single structure which contains separate areas used as hydrologic laboratories. The U.S. Geological Survey resides in the building and uses the labs to conduct tests utilizing Yucca Mountain geologic samples and water collected from the various water wells. These samples were previously collected in accordance with YMP quality procedures. No hazardous laboratory operations are conducted in the facility and all laboratory processes are conducted in accordance with technical procedures. This facility is centrally heated and cooled and equipped with potable water for the drinking fountains and the toilet and lab facilities.

Site Maintenance Building-The Site Maintenance Building is a single structure which contains separate hydrologic/testing support areas. The U.S. Geological Survey resides in the building as well, and uses the areas to supplement the testing utilizing Yucca Mountain geologic samples and water collected from the various water wells in accordance with YMP quality procedures. No hazardous laboratory operations are conducted in the facility. Small scale metal-working and welding process are conducted in the facility in accordance with approved procedures and processes. This facility is centrally heated and cooled and equipped with potable water for the drinking fountains and the toilet facilities.

\subsection{OFFICES, SCIENCE CENTERS, AND WAREHOUSE FACILITIES}

The YMP leases office buildings in Las Vegas, Nevada, in Vienna, Virginia, and in Washington, D.C. These leased facilities are commercial office buildings that meet all applicable building codes and standards. The building owners are responsible for maintaining these buildings and ensuring that they continue to meet all applicable codes and standards. The YMP activities that are performed in these buildings are engineering analyses, design, and business administrative; all of these activities are within the intended purpose of these buildings. The YMP leases office buildings in Las Vegas, Pahrump, and Beatty, Nevada, for use as Science Centers to educate and provide YMP information to the public. The Science Centers consist of displays and literature that describe the Project to the public and are consistent with the intended operations of these leased facilities. In addition, the YMP leases a warehouse (on Arville St.) in Las Vegas, which also meets all applicable building codes and standards. This warehouse is used for shipping and receiving as well as to store computer equipment and office furnishings. The warehouse owner is responsible for ensuring that the warehouse continues to meet all applicable codes and standards, and the YMP only uses it for its intended purpose. 


\section{HAZARD BASELINE}

\subsection{HAZARD BASELINE METHODOLOGY}

The guidance on hazard baseline documentation involving the identification and control of radiological and non-radiological hazards is provided in DOE-EM-STD-5502-94. This standard contains criteria for the grouping of facilities into nuclear, radiological, non-nuclear, or industrial classifications. Facilities are grouped to determine the type, grading, and complexity of the documentation required for hazard identification and control (and the corresponding review and approval process). Figure A-1 provides a flowchart that illustrates the DOE-EM-STD-5502-94 guidance for the baseline grouping for a facility.

\subsubsection{Radiological Inventory Assessment Methodology}

The criteria for determining the radiological hazard categorization of a facility are provided in DOE-STD-1027-92. In DOE Order 5480.23, three hazard categories are defined. A facility is designated as Hazard Category 1 if an analysis of hazards indicates that there is a potential for significant off-site consequences; Hazard Category 2 if the hazard analysis indicates that there is a potential for significant on-site consequences; and Hazard Category 3 if the analysis indicates that a potential exists for significant localized consequences only. A facility that does not exceed the Hazard Category 3 threshold criteria, but possesses radioactive materials whose potentially releasable inventory quantities meet or exceed the Reportable Quantity (RQ) levels listed in Appendix B of 40 CFR 302.4, is designated a Radiological Facility.

The inventory assessment conducted to determine the hazard categorization is performed without credit taken for engineered features or ACs. Examples of engineered features and ACs include specific facility features (not including site location) such as building containment, stacks, equipment, systems, actions, or operating conditions that are established to control risk.

In general, the radiological evaluation is accomplished by comparing the inventory of each radionuclide to the Threshold Quantity (TQ) levels provided in Table A.1 of DOE-STD-1027-92. In addition, the quantity of mixed fission products is also considered. If the radionuclide inventory of a facility meets or exceeds the Hazard Category 3 TQs provided in Table A.1, the facility is classified as a Nuclear Facility. Facilities that do not meet or exceed the Hazard Category 3 TQs are evaluated to determine if they should be classified as a Radiological Facility, a Non-Nuclear Facility, or an Other Industrial Facility. The criteria for differentiating between a Non-Nuclear Facility and an Industrial Facility are provided in Section 3.1.2 of this report.

Once a facility is determined to be a Nuclear Facility, a specific hazard categorization is determined. The criteria for determining the hazard categorization of nuclear facilities based on the radiological evaluations are established as follows:

\section{Hazard Category 1}

- The facility has the potential for significant off-site consequences based on total curie (Ci) content, potential material forms, and maximum energy for dispersion available. Only Category A Reactors or facilities designated by the Program Secretarial Officer are designated as Hazard Category 1 in accordance with DOE-STD-1027-92. 


\section{Hazard Category 2}

- The quantity of any radionuclide exceeds the Hazard Category 2 TQs provided in Table A.1 of DOE-STD-1027-92. This quantity is based on 1 rem at $100 \mathrm{~m}$ (on-site) as determined in 10 CFR 30 and modified by DOE.

- The minimum critical mass limit for any fissile material as specified in ANSI/ANS 8.1 is exceeded.

- The total quantity of mixed fission products, where the individual radionuclides have been determined, is greater than $1000 \mathrm{Ci}$.

- Where there are combinations of radioactive materials, the sum of the ratios of the quantity of each radionuclide to the Hazard Category 2 thresholds exceeds 1.0.

\section{Hazard Category 3}

- The quantity of any radionuclide exceeds the Hazard Category 3 TQs provided in Table A.1 of DOE-STD-1027-92. This quantity is based on 10 rem at $30 \mathrm{~m}$ for a 24-hour exposure.

- Where there are combinations of radioactive materials, the sum of the ratios of the quantity of each radionuclide to the Hazard Category 3 thresholds exceeds 1.0.

The criteria for determining if a facility is a Radiological Facility follow:

Radiological Facility

- Where there are combinations of radioactive materials, the sum of the ratios of the quantity of each radionuclide to the Hazard Category 3 thresholds is less than 1.0 but the facility contains radioactive materials whose potentially releasable RQ levels meet or exceed 40 CFR 302.4, Appendix B, levels.

Non-Nuclear or Other Industrial

- The potentially releasable radionuclide inventory is below the RQ levels of 40 CFR 302.4, Appendix B. The differentiation between non-nuclear and industrial is determined based on the chemical hazard evaluation.

\subsubsection{Chemical Inventory Assessment Methodology}

The assessment of the chemical inventory consists of a comparison of each chemical to the RQ levels reported in 40 CFR 302.4, the TQ levels reported in 29 CFR 1910.119, the TQ levels listed in 40 CFR 68, and the Threshold Planning Quantities (TPQs) reported in 40 CFR 355. The criteria for determining the facility baseline grouping based on the chemical evaluations are established as follows: 
Non-Nuclear

- The hazardous material inventory meets or exceeds the TQ levels of 29 CFR 1910.119.

- The hazardous material inventory meets or exceeds the TPQ levels of 40 CFR 355.

- The potentially releasable hazardous material meets or exceeds the RQ levels of 40 CFR 302.4, Table 302.4.

\subsection{HIGH HAZARD CHEMICAL FACILITY}

- The releasable radiological inventory is below the RQ levels for radiological materials, but has any gross chemical inventory greater than the TQ of 29 CFR 1910.119 or 40 CFR 68. If a chemical does not have a TQ, the TPQ levels of 40 CFR 355 will be used.

Low Hazard Chemical Facility

- The releasable radiological inventory is below the RQ levels of 40 CFR 302.4, Appendix B, for radiological materials; the gross chemical inventory is below the TQ levels of both 29 CFR 1910.119 and 40 CFR 68; and releasable chemical inventory is at or above the RQ levels of 40 CFR 302.4, Table 302.4. If a chemical does not have a TQ, the TPQ levels of 40 CFR 355 will be used.

Industrial

- The potentially releasable hazardous material is below the RQ levels of 40 CFR 302.4, Table 302.4 .

\subsection{ASSUMPTIONS}

3.3.1 The acetylene used at the ESF is stored in cylinders that hold 250 cubic feet of compressed gas. It is assumed in this analysis that each tank is full, and that this gas is stored at the industry standard pressure of $250 \mathrm{psi}$ at $70^{\circ} \mathrm{F}$. Under these conditions $(250$ cubic feet of compressed acetylene at 250 psi and $70^{\circ} \mathrm{F}$ ), 14.7 cubic feet of acetylene weighs one pound.

NOTE: Assumption 3.3.1 is used in Appendix A, calculations H, I, J, and W.

3.3.2 Release Fractions (RFs) from Attachment 1 of DOE-STD-1027-92 were used to conservatively calculate the potentially releasable hazardous material quantities (radiological and chemical) for comparison with the RQ values of Table 302.4 (chemicals) and Appendix B (radionuclides) of 40 CFR 302.4. Specifically, the following RFs were used. 


$\begin{array}{ll}\text { Material } & \text { RF } \\ \text { Highly Volatile/Combustible } & 0.5 \\ \text { Semi-Volatile } & 1.0 \mathrm{E}-02 \\ \text { Unknown Form } & 1.0 \mathrm{E}-02 \\ \text { Nonvolatile Powder } & 1.0 \mathrm{E}-03 \\ \text { Nonvolatiles in non-flammable liquid } & 1.0 \mathrm{E}-03\end{array}$

NOTE: Assumption 3.3.2 is used in Appendix A, Tables A-2 and A-4.

\subsection{RADIOLOGICAL MATERIAL INVENTORY, ASSESSMENT, AND EVALUATION}

Radionuclides are present at Area 25 and at the YMP site characterization activities in the form of sealed radioactive solid sources as well as unsealed liquid sources. These sources are stored in approved radioactive material storage areas in the vicinity of the ESF pad. In Attachment 1 of DOE-STD-1027-92, it is stated that sealed radioactive sources that are engineered to pass the special form testing specified by the Department of Transportation, and are handled according to a source control policy, may be excluded from a summation of the radioactive inventory of a facility.

To evaluate the unsealed sources, as per the Radiological Inventory Assessment Methodology, the inventory of these (unsealed) sources was compared to the Hazard Category 3 Thresholds presented in DOE-STD-1027-92. The results of this comparison are presented in Table A-1 in Appendix A. The inventory of unsealed sources was obtained from the Sealed Source and Radioactive Material Inventory (CRWMS M\&O 2000). For conservatism, this evaluation assumed that all the sources were collocated. As per the methodology, the sum of the ratios of the quantity of each radionuclide to the Hazard Category 3 thresholds was calculated. Because the sum of the ratios did not exceed the value of 1.0, a further determination was required, as presented in Figure 1 in Appendix A. The potentially releasable radionuclide inventory was calculated using the same inventory and RFs obtained from Attachment 1 of DOE-STD-1027-92. The potentially releasable inventory was then compared to RQ levels for each radionuclide from Appendix B of 40 CFR 302.4. These calculations are presented in Table A-2 in Appendix A. The individual sources, as well as the sums of quantities of the same radionuclide sources in similar locations, are presented. No RQs were exceeded, whether the sources were examined as individual sources or as summed quantities of like sources. Based on these assessments of the radioactive inventories, the YMP site characterization activities are classified as Other Industrial.

\subsection{HAZARDOUS MATERIAL INVENTORY AND ASSESSMENT}

The inventory of hazardous materials at the existing Area 25 facilities within the NTS, as well as all other facilities that support the YMP site characterization activities, is documented and maintained in the M\&O Material Inventory Lotus Notes database. The hazardous materials inventory consists of quantities of chemicals and industrial products required for the various YMP activities, including chemicals used in various laboratories as well as those chemical and industrial products used in support of the ESF construction, testing, and sampling activities. These chemicals are listed and sorted in the M\&O Material Inventory Lotus Notes database by their location, material name, organization, and material type. For completeness, the inventories 
for all ESF facilities as well as all Area 25, NTS facilities, and other additional facilities that support the YMP site characterization activities (and had inventories documented in the Lotus Notes database), were included in this assessment. The inventories of off-site facilities (such as the Atlas Facility, the Beatty Science Center) were also considered. An initial screening of the inventory was performed. The following criteria were used to eliminate certain chemicals and products in the database listing:

- "Any substance to the extent it is used for personal, family, or household purposes, or is present in the same form and concentration as a product packaged for distribution and use by the general public," can be eliminated from being categorized as a hazardous chemical in accordance with 40 CFR 355.20. This category would include such items as cleaners, paints, toners, rustmaster, diesel fuel, adhesives, welding materials, and petroleum jelly.

- The material is used in a laboratory setting, in laboratory-scale quantities. This category would also include such items as buffer solutions, resin, glove dust, indicator solutions, and silica gel. The exclusion of laboratory materials is consistent with 40 CFR 355.20, where the U.S. Environmental Protection Agency definition of "hazardous chemicals" specifically excludes "any substance to the extent it is used in a research laboratory or a hospital or other medical facility under the direct supervision of a technically qualified individual." Laboratory setting and laboratory quantities are defined in 29 CFR 1910.1450. "Laboratory' means a facility where 'laboratory use of hazardous chemicals' occurs. It is a workplace where relatively small quantities of hazardous chemicals are used on a non-production basis." "Laboratory scale' means work with substances in which the containers used for reactions, transfers, and other handling of substances are designed to be easily and safely manipulated by one person. 'Laboratory scale' excludes those workplaces whose function is to produce commercial quantities of materials." For completeness, all quantities of chemicals and chemical solutions were included in the evaluation of the hazardous material inventory; and the standard solutions, buffer solutions, and other common laboratory items were screened out.

- Oil is excluded from the definition of a hazardous material in accordance with DOE Order 5480.23.

- Explosives were screened from consideration because these materials are not manufactured at the ESF. Storage and use of explosives are addressed by 29 CFR 1910.109 and are common industrial hazards. The Occupational Safety and Health Administration has issued an interpretation stating that only the manufacture of explosives is addressed by 29 CFR 1910.119 , not the storage and use of these materials (Miles 1998).

- Gasoline and diesel fuel were screened from consideration because they are exempt from consideration under 29 CFR 1910.119 and 40 CFR 68.

The hazardous materials selected for evaluation are listed in Tables A-3 and A-4 in Appendix A. The North Las Vegas Test Facility is the only non-ESF facility with chemical inventories requiring evaluation. 


\subsection{CHEMICAL HAZARDS EVALUATION}

As per the Chemical Inventory Assessment Methodology, the chemicals in the hazardous material inventory for the YMP (Area 25 and North Las Vegas Test Facility), that were selected for evaluation, were compared to the TPQs of 40 CFR 355, the TQs of 40 CFR 68.130, and the TQs of 29 CFR 1910.119, and are presented in Tables A-3 and A-4 in Appendix A. None of these chemicals exceeded any of the available TPQs or TQs listed in these CFRs.

Additionally, the Chemical Inventory Assessment Methodology, in accordance with DOE-STDEM-5502-94, stipulates that a comparison be made between the potentially releasable quantities of the chemicals in the hazardous material inventory selected for evaluation and the RQs (if available for these chemicals) listed in Table 302.4 of 40 CFR 302. The inventory quantities of the chemicals that have RQs available in Table 302.4 were multiplied by the appropriate RFs to obtain the potentially releasable quantities. As discussed in Assumption 3.3.2, RFs from Attachment 1 of DOE-STD-1027-92 were used in this analysis. Specifically:

- An RF of 0.5 was used for volatile chemicals such as toluene.

- 1.0E-02 was used for semi-volatile chemicals (semi-volatile liquids such as hydrochloric acid or nitric acid) and chemicals of unknown form (such as mercury, which is a liquid metal with a very low vapor pressure).

- 1.0E-03 was used for nonvolatile powders (chemicals stored in powder form, such as sodium hydroxide) and nonvolatiles in non-flammable liquid (such as solutions of sodium hydroxide).

Therefore, the inventories of these chemicals were multiplied by the appropriate RFs to obtain the quantities of their inventories that are potentially releasable, and these inventories were compared to the RQs of Table 302.4 of 40 CFR 302. The results of this analysis are presented in Tables A-5 and A-6 in Appendix A. In each case, the potentially releasable quantity of the chemical was less than the respective 40 CFR 302 RQ limit.

\subsection{HAZARD BASELINE DETERMINATION}

Sealed and unsealed radioactive sources are used in YMP site characterization activities; however, some sealed sources are exempt from consideration because they meet sealed-source guidelines discussed in DOE-STD-1027-92. An evaluation of the unsealed sources presented in Table A-1 in Appendix A demonstrated that there are no radionuclides present in quantities that are greater than the associated Hazard Category 3 threshold quantities, and the YMP site characterization activities are not classified as a Nuclear Facility or as a Radiological Facility. A comparison of the releasable quantities of radionuclides to the Appendix B RQs of 40 CFR 302.2 resulted in a classification of Other Industrial Facility.

An evaluation comparing the inventories of potentially hazardous chemicals to the TPQs, and TQs, is provided in Tables A-3 and A-4 in Appendix A. A comparison of the potentially releasable quantities of chemicals (having available RQs in Table 302.4 of 40 CFR 302) to the RQs (presented in Tables A-5 and A-6 in Appendix A), determined that none of these quantities 
exceeded the RQ limits. In accordance with the classification criteria, the Area 25 facilities within the NTS that support the site characterization activities have a chemical hazard classification of Industrial Facility.

\subsection{HAZARD BASELINE CONCLUSION}

The radiological analysis performed in accordance with DOE-STD-1027-92 demonstrates that the inventory of radiological materials at the Area 25 facilities within the NTS, is less than the Hazard Category 3 threshold limits and, in accordance with DOE-EM-STD-5502-94, is therefore not a Nuclear Facility. In addition, the comparison of the radiological inventory to the RQs of 40 CFR 302.4, Appendix B, demonstrates that, in accordance with DOE-EM-STD-5502-94, the facility is not a Radiological Facility, but instead is an Other Industrial Facility. The chemical analysis performed in accordance with DOE-EM-STD-5502-94 does not result in a classification of Non-Nuclear Facility, High-Hazard Chemical Facility, or Low-Hazard Chemical Facility; instead, it results in a chemical hazard classification of Industrial Facility.

These analyses are based on the appropriate radiological and chemical inventories currently present at the Area 25 facilities within the NTS, as well as the other facilities that support the YMP site characterization activities. The M\&O Material Inventory on the Lotus Notes database provides the accountable radioactive sources and the chemical inventories. The results and conclusions of this assessment are not valid for radiological or chemical inventories greater than those used in these analyses. 
INTENTIONALLY LEFT BLANK 


\section{SYSTEM DESIGN AND HAZARD ANALYSIS SUMMARY}

\subsection{DESIGN PROCESS}

The design control process establishes a means by which safety features are engineered into the $\mathrm{A} / \mathrm{E}$ design, in addition to requirements established by national consensus codes and standards, Project requirements, etc. In conjunction with the design effort, System Safety Analyses are performed to identify and evaluate hazards associated with the system. The ESF systems discussed in Section 2 have been constructed by one of three methods:

- $\mathrm{A} / \mathrm{E}$ designed system was installed

- System was designed and installed under Alternate Construction (see Section 4.2)

- System was installed as a constructor-furnished temporary structure

At a minimum, all systems are mandated to meet the requirements established in 29 CFR 1926, Safety and Health Regulations for Construction (Dyer 1998).

\subsection{ALTERNATE CONSTRUCTION}

To enhance ESF TS Loop TBM productivity, and to defer costs associated with procurement and installation of $\mathrm{A} / \mathrm{E}$ designed systems, an alternative approach was adopted for the design and installation of construction utilities. Rather than install the $\mathrm{A} / \mathrm{E}$ systems that were designed for multiple simultaneous construction headings, testing, and operations activities, Alternate Construction allowed the Constructor to select and install construction systems similar to those used in commercial tunneling systems. These systems were the responsibility of the Constructor, and were intended to be replaced by the A/E designed utility systems for ESF operations after the breakthrough of the TBM at the South Portal. However, following the breakthrough, the decision was made to evaluate the systems for continued use. These evaluations were made in Title III Evaluation Reports (see Section 4.3).

\subsection{TITLE III EVALUATION REPORTS}

Following completion of ESF TS Loop TBM operations, a plan was implemented to evaluate systems installed under Alternate Construction and determine if modifications to the systems and/or the system design were recommended to reduce costs, improve operational effectiveness, or comply with current regulations and requirements. These results were summarized in Title III Evaluation Reports. These reports evaluated 15 ESF systems:

- Conveyor System

- Subsurface Lighting System

- Material and Personnel Handling System

- Access Road System

- Non-Q Ground Support

- Sanitation System

- Muck Storage

- Security System

- Surface and Subsurface Communication System 
- Surface Portion of the Non-Potable Water System

- Subsurface Fire Water System and Subsurface Portion of the Non-Potable Water System

- Surface and Subsurface Power System

- North Portal Pad Drainage

- Waste Water System

- Compressed Air System

The scope of the Title III Evaluation Reports included the following primary tasks:

- Compare the as-constructed system with the baseline design

- Compare the as-constructed system with the baseline requirements (ESFDR)

- Compare the as-constructed system with operating permit(s) requirements

- Compare the as-constructed system with environmental and safety requirements

- Determine the required as-constructed documents

- Identify additional design and construction work

- Provide cost and schedule estimates for recommended additional work

Following completion of the Title III Evaluation Reports, an evaluation of the recommended additional work was performed by System Safety to determine what work could be deferred and not create, or fail to correct, an unacceptable risk to personnel (Gwyn 1999b).

As an Industrial Facility, the hazards tend to be well known, well understood, and well characterized. The design, construction, and operations required to mitigate or prevent these hazards are addressed with national consensus codes and standards. Therefore, the hazards analyses for Industrial Facilities are included in the analyses performed for the design. These design analyses include a System Safety Analysis, Preliminary Hazards Analysis, and a Fire Hazards Analysis. 


\section{FUNCTIONAL CLASSIFICATION}

\subsection{FUNCTIONAL CLASSIFICATION METHODOLOGY}

This section describes the methodology for identifying functions (and the SSCs or ACs that are credited with performing these functions) that reduce the risk to the public and workers from uncontrolled releases of radioactive and other hazardous materials. In addition, it provides the methodology for assigning FCLs to SSCs. Functional Classification is a graded classification system used to determine the minimum requirements for SSCs (i.e., requirements for design, operation, procurement, and maintenance). The four FCLs, in order of precedence, are specified as FCLs 1 through 4 . While FCL1 and FCL2 are selected based on the safety function performed by an SSC, FCL3 is based on functions that are essential to performing the Project mission. FCL4 includes all SSCs not included in FCL1, FCL2, and FCL3. This methodology applies to the classification of SSCs in existing facilities, new facilities, and modifications to existing facilities.

The Functional Classification process reviews the functions performed by the SSCs. An FCL is assigned to an SSC based on this review and the criteria described below. SSCs may perform multiple functions; therefore, more than one of these criteria may apply. An SSC is assigned the highest applicable classification level based on a review of its functions against these criteria. Consequently, the functions of an SSC are reviewed against all criteria, from highest to lowest, and the SSC is assigned an FCL based on the highest applicable criteria.

SSCs often perform a function to prevent or mitigate common industrial hazards. Common industrial hazards are defined as materials or energy sources that are routinely encountered in general industry and construction, and for which national consensus codes and/or standards (e.g., Occupational Safety and Health Administration and transportation safety) exist and have been implemented to guide safe design, construction, and operation. During the hazard identifications processes routinely used in the DOE Complex, common industrial hazards are not typically evaluated. However, they are evaluated to the extent that they could act as initiators and/or contributors to events that potentially could result in a radiological or chemical release. This methodology is followed to clearly delineate the level of control placed on those SSCs used to mitigate hazards. Hazards that are unique to the DOE Complex, and thus require a more rigorous level of control, are addressed in a Hazard Analysis and in a Functional Classification process. Hazards common to industry are controlled through the implementation of national consensus codes and/or standards. Therefore, functions performed by SSCs to mitigate common industrial hazards are not considered when assigning an FCL.

\subsubsection{Functional Classification Criteria}

\subsubsection{FCL1}

Loss of functions of SSCs that prevent or mitigate hazards common to the mining and/or tunneling industries are not considered in this classification process. These hazards are included in those hazards referred to as common industrial hazards. However, if adverse consequences to the public result from a hazard unique to the YMP, and if these consequences result from the loss of function of an SSC, the function of that SSC must be considered in this definition. For the 
purposes of Functional Classification, the public is considered to be individuals located at or beyond the site boundary.

The FCL1 functional and safety classification applies to those functions performed by SSCs or ACs whose failure to perform their defined functions could:

- Result in an exposure to an individual member of the public to airborne concentrations of a chemical hazard equal to or greater than Emergency Response Planning Guideline 2

- Cause serious injury or death to a member of the public (fatal injury)

- Cause severe long-term damage to the environment beyond the site boundary

\subsubsection{FCL2}

Loss of functions of SSCs that prevent or mitigate common industrial hazards such as those associated with mining and/or tunneling industries (for the ESF) are not considered in this classification process. However, if adverse consequences to the public result from a hazard unique to the YMP, and if these consequences result from the loss of function of an SSC, the function of that SSC must be considered in this definition.

The FCL2 functional and safety classification applies to those functions performed by SSCs and ACs whose failure could result in:

- Exposure to a chemical hazard in airborne concentrations equal to or greater than Emergency Response Planning Guideline 2

- Serious injury or death to a worker

- Minor injury or illness to a member of the off-site public

- Severe long-term damage to the environment within the site boundary

- Loss of use of major facility functions or processes resulting in severe mission or economic impact

Based on a qualitative evaluation in a Hazard Analysis, such a failure could result in a prompt worker (any worker group) fatality or serious injury from consequences where the primary threat is not from exposure to radioactive or toxic material.

\subsubsection{FCL3}

The FCL3 classification applies to those SSC and AC functions whose loss or failure could have an unacceptable impact on a facility by causing damage to the facility or a process resulting in serious mission or economic impact. 


\subsubsection{FCL4}

The FCL4 functional and safety classification is assigned to all SSCs not required to provide an FCL1, FCL2, or FCL3 function. Failure of an FCL4 SSC or AC function would have no probable impact on a worker or member of the off-site public, have no probable impact on the environment, and minimal impact to the facility mission. All SSC and AC functions are, as a minimum, classified as FCL4 to ensure that proper design, operations, and maintenance requirements are assigned to provide for the health and safety of the worker and environment and to ensure compliance with other requirements.

\subsubsection{Functional Classification Process}

\subsubsection{FCL1}

The FCL1 classification only applies to Nuclear Facilities and High Hazard Chemical Facilities. Only these facilities have an inventory of hazardous material, if released, sufficient to result in off-site impacts in excess of the FCL1 evaluation criteria. To determine if an SSC performs an FCL1 function, the following steps are performed.

First, a review of applicable documentation is undertaken to determine if there is a potential for exceeding FCL1 criteria. All of the following conditions must exist for functions to be classified as FCL1:

- A sufficient inventory must exist, such that, if released in total, it would exceed FCL1 criteria (Section 5.1.1.1).

- An exposure path and mechanism for release must exist.

- The frequency of the unmitigated release event must be considered credible.

Finally, the FCL1 functions that are required to meet the FCL1 criteria are determined, as well as a determination of which SSCs or ACs perform the FCL1 functions.

The proposed list of SSCs and ACs is used to determine if the FCL1 criteria are no longer exceeded with the respective SSCs/ACs in place. The results of this analysis are provided to the Responsible Engineer to either confirm the correct identification of SSCs and ACs or to revise the list (add or delete). This process continues until the selection of SSCs and ACs ensures that the FCL1 criteria are met. The SSCs selected through this process are classified as FCL1. The FCL1 criteria should not be viewed as a "speed limit"; instead, it is preferred that the mitigated analysis results be "well below" the respective criteria guidelines. However, there may be unusual cases where the cost involved in necessary facility modifications to meet the FCL1 criteria cannot be justified. These results must be documented in the facility Safety Basis Report and agreed to by the DOE, as indicated by the DOE approval of the Safety Basis Report.

The FCL2 selection of SSCs and ACs is performed after completion of the FCL1 selections. 


\subsubsection{FCL2}

The FCL2 classification applies to Nuclear Facilities and those Radiological, High Hazard Chemical, Low Hazard Chemical, and Industrial Facilities with unique hazards not considered to be common industrial hazards.

First, a review of applicable documentation is performed to determine if there is a potential for exceeding the FCL2 criteria (Section 5.1.1.2).

Finally, the FCL2 functions that are required to meet FCL2 criteria are selected (Section 5.1.1.2), as well as a determination of which SSCs or ACs perform the FCL2 functions, in the same manner as was performed for the FCL1 functions.

The FCL3 SSC/AC selections are performed after completion of the FCL2 selections.

\subsubsection{FCL3}

A review of the applicable documentation (e.g., Design, Preliminary Hazard Analysis, Work Instructions, and the Emergency Plan) is performed to determine the SSCs and ACs that are required to meet the FCL3 criteria (Section 5.1.1.3).

The FCL3 classification is applied only to the SSCs required to meet the FCL3 functions. Unlike the applications required for the FCL1 and FCL2 classifications, the supporting SSCs (required to ensure that the required function can be provided or to ensure that the required function is not prevented) are not required to be classified as FCL3.

\subsubsection{FCL4}

As previously noted, all SSC and AC functions are, as a minimum, classified as FCL4 to ensure that proper design, operations, and maintenance requirements are assigned to provide for the health and safety of the worker and environment and to ensure compliance with other requirements.

\subsection{SYSTEM FUNCTIONAL CLASSIFICATIONS}

The systems that make up the YMP facilities (identified in Section 2) are classified in the following subsections using the functional classification criteria identified in Section 5.1.1. The results of these classifications are summarized in Tables 5-1 through 5-4).

\subsubsection{ESF System Classification}

The ESF systems identified in Section 2 are classified in the following subsections using the Functional Classification criteria identified in Section 5.1.1. The results of these classifications are summarized in Table 5-1. 


\subsubsection{ESF Subsurface Ventilation System}

The ESF Subsurface Ventilation System mitigates hazards commonly associated with the tunneling/mining industry; these hazards are not unique to the YMP site characterization activities. The loss of the Ventilation System would not result in a life-threatening situation because there is a sufficient quantity of air to prevent asphyxiation, and the use of personal protective equipment mitigates the hazards associated with the accumulation of airborne hazardous materials. Furthermore, in the case of a loss of the Ventilation System, operations are halted and the tunnel is evacuated of personnel. However, the Ventilation System is necessary to conduct tunnel operations and any loss of the system could negatively impact the Project mission. The Ventilation System is classified as FCL3.

Table 5-1. Functional Classification of ESF Systems

\begin{tabular}{|l|l|l|}
\hline \multicolumn{1}{|c|}{ SYSTEM DESCRIPTION } & \multicolumn{1}{|c|}{$\begin{array}{c}\text { Functional } \\
\text { Classification }\end{array}$} & \multicolumn{1}{|c|}{ SAFETY ENVELOPE } \\
\hline Compressed Air & FCL3 & N/A \\
\hline Communication & FCL3 & N/A \\
\hline ECRB Refuge Chambers & FCL3 & N/A \\
\hline Ground Support Q & FCL3 & N/A \\
\hline Ground Support Non-Q & FCL3 & N/A \\
\hline Subsurface Ventilation & FCL3 & N/A \\
\hline Power & FCL3 & N/A \\
\hline Surface Non-Potable Water & FCL3 & N/A \\
\hline Subsurface Fire and Non-Potable & FCL3 & N/A \\
Water & & \\
\hline Data Acquisition & FCL3 & N/A \\
\hline Conveyor & FCL4 & N/A \\
\hline Waste Water & FCL4 & N/A \\
\hline Material and Personnel Handling & FCL4 & N/A \\
\hline Potable Water & FCL4 & N/A \\
\hline Muck Storage & FCL4 & N/A \\
\hline Surface Sanitation & FCL4 & N/A \\
\hline Subsurface Sanitation & FCL4 & N/A \\
\hline Subsurface Lighting & FCL4 & N/A \\
\hline
\end{tabular}


Table 5-1. Functional Classification of ESF Systems (Continued)

\begin{tabular}{|l|c|l|}
\hline \multicolumn{1}{|c|}{ SYSTEM DESCRIPTION } & $\begin{array}{c}\text { Functional } \\
\text { Classification }\end{array}$ & \multicolumn{1}{c|}{ SAFETY ENVELOPE } \\
\hline Access Roads & FCL4 & N/A \\
\hline North Portal Pad Drainage & FCL4 & N/A \\
\hline South Portal Pad Drainage & FCL4 & N/A \\
\hline Change House & FCL4 & N/A \\
\hline Switchgear Building & FCL4 & N/A \\
\hline Security System & FCL4 & N/A \\
\hline Topsoil/Rock Storage & FCL4 & N/A \\
\hline Explosive Storage & FCL4 & N/A \\
\hline Parking Areas & FCL4 & N/A \\
\hline Warehouse & FCL4 & N/A \\
\hline Shop Building & FCL4 & N/A \\
\hline Operations Building & FCL4 & N/A \\
\hline ESF Visitors Center & FCL4 & N/A \\
\hline
\end{tabular}

N/A Not Applicable

\subsubsection{ESF Conveyor System}

The hazards associated with the ESF Conveyor System are mitigated by safety features that have been engineered into the equipment design and are required by national consensus codes and standards. The loss of the Conveyor System would not result in a life-threatening situation because the system does not provide a safety function to the facility. Loss of the Conveyor System would not negatively impact the Project mission because there are temporary areas available underground to store accumulated muck. The Conveyor System is classified as FCL4.

\subsubsection{ESF Power System}

The hazards associated with the ESF Power System are common to the tunneling/mining industry and are not unique to the site characterization activities. The loss of the Power System could result in an impact to the Project mission because the system is linked to other systems and must inherit the highest FCL of those systems. Reviewing Table 5-1, the highest FCL of systems fed by the Power System is FLC3 (ventilation, refuge chambers, and compressed air). However, loss of the Power System would not affect the Compressed Air System because the Compressed Air System is backed up by a diesel-powered compressor. Therefore, the Power System is classified as FCL3.

\subsubsection{ESF Compressed Air System}

The hazards associated with the ESF Compressed Air System are common to the tunneling/mining industry. The loss of the Compressed Air System would not result in a serious 
injury or death a the worker in the ECRB; however, loss of this system could have a negative impact on the Project mission. The Compressed Air System is, therefore, classified as FCL3.

\subsubsection{ESF Waste Water System}

The hazards associated with the ESF Waste Water System are common to the tunneling/mining industry and are not unique to the YMP site characterization activities. The loss of the Waste Water System would not result in a life-threatening situation because the system does not 
provide a safety function to the facility. The loss of the Waste Water System would not negatively impact the Project mission because there are sumps and a tank available for temporary storage. The Waste Water System is classified as FCL4.

\subsubsection{ESF Material And Personnel Handling System}

The hazards associated with the ESF Material and Personnel Handling System are common to the tunneling/mining industry and are not unique to the YMP site characterization activities. The loss of the Material and Personnel Handling System would not result in a life-threatening situation because the system does not provide a safety function to the facility. The loss of the Material and Personnel Handling System would not negatively impact the Project mission because access to areas can be reached on foot. The Material and Personnel Handling System is classified as FCL4.

\subsubsection{ESF Communication System}

The function of the ESF Communication System is to mitigate consequences of a fire, which is a common industrial hazard. Failure of this function could adversely impact the Project's ability to complete its mission. Therefore, the Communication System is classified FCL3.

\subsubsection{ESF Potable Water System}

The ESF Potable Water System does not provide a safety function to the facility and does not mitigate any unique hazards associated with the YMP site characterization activities; loss of the system would not negatively impact the Project mission. The Potable Water System is classified as FCL4.

\subsubsection{ESF Non-Potable Water System}

ESF Surface Non-Potable Water System-The ESF Surface Non-Potable Water System mitigates hazards commonly associated with the tunneling/mining industry; these hazards are not unique to the YMP site characterization activities. The loss of the Surface Non-Potable Water System could adversely impact the Project mission because it provides incipient fire protection for the surface facilities. Therefore, Surface Non-Potable Water System is classified as FCL3.

ESF Subsurface Fire Water System and Subsurface Portion of the Non-Potable Water System-The ESF Subsurface Fire Water System and Subsurface Portion of the Non-Potable Water System mitigates hazards commonly associated with the tunneling/mining industry; these hazards are not unique to the YMP site characterization activities. The loss of the Subsurface Fire Water System and Subsurface Portion of the Non-Potable Water System could adversely impact the Project mission since it provides incipient fire protection underground. Therefore, Subsurface Fire Water System and Subsurface Portion of the Non-Potable Water System are classified as FCL3.

\subsubsection{ESF Muck Storage System}

The ESF Muck Storage System does not provide a safety function to the facility and does not mitigate any unique hazards associated with the YMP site characterization activities. Loss of 
this system would not negatively impact the Project mission. The Muck Storage System is classified as FCL4.

\subsubsection{ESF Ground Support System}

The ESF Ground Support System mitigates hazards commonly associated with the tunneling/mining industry; these hazards are not unique to the YMP site characterization activities. Although a complete failure of the system is highly unlikely, the loss of a portion of the Ground Support System (i.e., a keyblock) could negatively impact the Project mission. Therefore, Ground Support System is classified as FCL3.

\subsubsection{ESF Sanitation System}

The ESF Sanitation System does not provide a safety function to the facility and does not mitigate any unique hazards associated with the YMP site characterization activities. Loss of this system would not negatively impact the Project mission. The Sanitation System is classified as FCL4.

\subsubsection{ESF Subsurface Lighting System}

The hazards associated with the ESF Subsurface Lighting System are common to the tunneling/mining industry; these hazards are not unique to the YMP site characterization activities. The loss of the Subsurface Lighting System would not present a life-threatening situation or negatively impact the Project mission because the use of personal protective equipment (i.e., a cap lamp) mitigates the hazards. The Subsurface Lighting System is classified as FCL4.

\subsubsection{ESF Access Road System}

The ESF Access Road System does not provide a safety function to the facility and does not mitigate any unique hazards associated with the YMP site characterization activities. Loss of the Access Road System would not negatively impact the Project mission. The Access Road System is classified as FCL4.

\subsubsection{ESF North Portal Pad Drainage System}

The ESF North Portal Pad Drainage System does not provide a safety function to the facility and does not mitigate any unique hazards associated with the YMP site characterization activities. The loss of this system would not negatively impact the Project mission. The North Portal Pad Drainage System is classified as FCL4.

\subsubsection{ESF South Portal Pad Drainage}

The ESF South Portal Pad Drainage System does not provide a safety function to the facility and does not mitigate any unique hazards associated with the YMP site characterization activities. A loss of this system would not negatively impact the Project mission. The South Portal Pad Drainage System is classified as FCL4. 


\subsubsection{ESF Change House}

The hazards associated with the ESF Change House are common to the tunneling/mining industry; these hazards are not unique to the YMP site characterization activities. The loss of the Change House would not result in a life-threatening situation or negatively impact the Project mission because backups exist for both the mine rescue equipment and locker/shower facilities. (NOTE: The Field Operations Center would need to be reopened in this event.) The Change House is classified as FCL4.

\subsubsection{ESF Switchgear Building}

The hazards associated with the ESF Switchgear Building are common to the tunneling/mining industry; these hazards are not unique to the YMP site characterization activities. The loss of the Switchgear Building would not result in a life-threatening situation or negatively impact the Project mission because the Compressed Air System is backed-up by a diesel-powered compressor. The Switchgear Building is classified as FCL4.

\subsubsection{ESF Security System}

The ESF Security System does not provide a safety function to the facility and does not mitigate any unique hazards associated with the YMP site characterization activities. The loss of this system would not negatively impact the Project mission. The Security System is classified as FCL4.

\subsubsection{ESF Topsoil/Rock Storage}

The ESF Topsoil/Rock Storage does not provide a safety function to the facility and does not mitigate any unique hazards associated with the YMP site characterization activities. A loss of this system would not negatively impact the Project mission. Topsoil/Rock Storage is classified as FCL4.

\subsubsection{ESF Explosive Storage Facility}

The ESF Explosive Storage Facility does not provide a safety function to the facility and does not mitigate any unique hazards associated with the YMP site characterization activities. The loss of this system would not negatively impact the Project mission. Explosive Storage is classified as FCL4.

\subsubsection{ESF Data Acquisition}

The ESF Data Acquisition System does not provide a safety function to the facility and does not mitigate any unique hazards associated with the YMP site characterization activities. However, the loss of the Data Acquisition System could negatively impact the Project mission. Data Acquisition System is classified as FCL3. 


\subsubsection{ESF Parking Areas}

The ESF Parking Areas do not provide a safety function to the facility and do not mitigate any unique hazards associated with the YMP site characterization activities. A loss of the Parking Areas would not negatively impact the Project mission. Parking Areas are classified as FCL4.

\subsubsection{ESF Warehouse}

The ESF Warehouse does not provide a safety function to the facility and does not mitigate any unique hazards associated with the YMP site characterization activities. A loss of the Warehouse would not negatively impact the Project mission. The Warehouse is classified as FCL4.

\subsubsection{ESF Shop Building}

The ESF Shop Building does not provide a safety function to the facility and does not mitigate any unique hazards associated with the YMP site characterization activities. A loss of the Shop Building would not negatively impact the Project mission. The Shop Building is classified as FCL4.

\subsubsection{ESF Operations Building}

The ESF Operations Building does not provide a safety function to the facility and does not mitigate any unique hazards associated with the YMP site characterization activities. A loss of the Operations Building would not negatively impact the Project mission. The Operations Building is classified as FCL4.

\subsubsection{ESF Visitor Center}

The ESF Visitor Center does not provide a safety function to the facility and does not mitigate any unique hazards associated with the YMP site characterization activities. A loss of the ESF Visitor Center would not negatively impact the Project mission. The ESF Visitor Center is classified as FCL4.

\subsubsection{ESF ECRB Refuge Chambers}

The function of the ESF ECRB Refuge Chambers is to mitigate the consequences of an underground fire in the ECRB cross-drift. The risk level of fire scenarios in the ECRB was evaluated in a System Safety Analysis. The Hazard Classification for the six scenarios evaluated in this report ranged from Low to Extremely Low (BSC 2001d). The refuge chambers at Alcove 8 and behind the bulkhead at Station $17+63$ at the page phone at Station $18+43$ were cited as mitigative/control features required to obtain these Hazard Classifications. In the mining industry the most likely incident which would warrant the use of a refuge chamber is an explosion and/or fire. Fires are considered to be hazards commonly associated with the tunneling/mining industry; these hazards are not unique to the YMP site characterization activities. In the mining industry refuge chambers are considered to be an aid to possible survival, not a life assurance tool (USBM 1983). Failure or loss of the mitigative/control function provided by refuge chambers could result in an adverse mission 
impact to the Project since they provide for underground fire protection Therefore, the ESF ECRB Refuge Chambers are classified as FCL3.

\subsubsection{Busted Butte Facilities System Classifications}

The Busted Butte systems identified in Section 2 are classified in the following subsections using the Functional Classification criteria identified in Section 5.1.1. The results of these classifications are summarized in Table 5-2 and in the subsections that follow. 
Table 5-2. Functional Classification of Busted Butte Systems

\begin{tabular}{|l|c|l|}
\hline \multicolumn{1}{|c|}{ SYSTEM DESCRIPTION } & $\begin{array}{c}\text { Functional } \\
\text { Classification }\end{array}$ & \multicolumn{1}{c|}{ SAFETY ENVELOPE } \\
\hline Communication & FCL3 & N/A \\
\hline Ground Support Non-Q & FCL3 & N/A \\
\hline Subsurface Ventilation & FCL3 & N/A \\
\hline Power & FCL3 & N/A \\
\hline Surface Non-Potable Water & FCL3 & N/A \\
\hline $\begin{array}{l}\text { Subsurface Fire and Non-Potable } \\
\text { Water }\end{array}$ & FCL3 & N/A \\
\hline Data Acquisition & FCL3 & N/A \\
\hline Compressed Air & FCL4 & N/A \\
\hline Potable Water & FCL4 & N/A \\
\hline Muck Storage & FCL4 & N/A \\
\hline Surface Sanitation & FCL4 & N/A \\
\hline Subsurface Lighting & FCL4 & N/A \\
\hline Access Roads & FCL4 & N/A \\
\hline Busted Butte Pad Drainage & FCL4 & N/A \\
\hline Security System & FCL4 & N/A \\
\hline Topsoil/Rock Storage & FCL4 & N/A \\
\hline Parking Areas & FCL4 & N/A \\
\hline Operations Building & FCL4 & N/A \\
\hline
\end{tabular}

N/A Not Applicable

\subsubsection{Busted Butte Subsurface Ventilation System}

The Busted Butte Subsurface Ventilation System mitigates hazards commonly associated with the tunneling/mining industry; these hazards are not unique to the YMP site characterization activities. The loss of the Ventilation System would not result in a life-threatening situation because there is a sufficient quantity of air to prevent asphyxiation, and the use of personal protective equipment mitigates the hazards associated with the accumulation of airborne hazardous materials. Furthermore, in the case of a loss of the Busted Butte Ventilation System, operations are halted and the tunnel will be evacuated of personnel. However, the Busted Butte Ventilation System is necessary to conduct tunnel operations and any loss of the system could negatively impact the Project mission. Therefore, the Busted Butte Ventilation System is classified as FCL3.

\subsubsection{Busted Butte Power System}

The hazards associated with the Busted Butte Power System are common to the tunneling/mining industry and are not unique to the YMP site characterization activities. The loss of the Busted Butte Power System could result in an impact to the Project mission because the system is linked to other systems and must inherit the highest FCL of those systems. 
Reviewing Table 5-2, the highest FCLs of systems fed by the Power System are FCL3. Therefore, the Busted Butte Power System is classified as FCL3.

\subsubsection{Busted Butte Compressed Air System}

The hazards associated with the Busted Butte Compressed Air System are common to the tunneling/mining industry. The loss of the Compressed Air System would not result in a serious injury or death, or affect the mission at Busted Butte. The Busted Butte Compressed Air System is therefore classified as FCL4.

\subsubsection{Busted Butte Communication System}

The function of the Busted Butte Communication System is to mitigate consequences of an accident or fire, which are common industrial hazards. Failure of this function could adversely impact the ability of the Project to complete the mission. Therefore, the Busted Butte Communication System is classified FCL3.

\subsubsection{Busted Butte Potable Water System}

The Busted Butte Potable Water System does not provide a safety function to the facility and does not mitigate any unique hazards associated with the YMP site characterization activities; loss of the system would not negatively impact the Project mission. Therefore, the Busted Butte Potable Water System is classified as FCL4.

\subsubsection{Busted Butte Non-Potable Water System}

Surface Non-Potable Water System-The Busted Butte Surface Non-Potable Water System mitigates hazards commonly associated with the tunneling/mining industry; these hazards are not unique to the YMP site characterization activities. The loss of the Surface Non-Potable Water System could adversely impact the Project mission because it provides incipient fire protection for the surface facilities. Therefore, the Busted Butte Surface Non-Potable Water System is classified as FCL3.

Subsurface Fire Water System and Subsurface Portion of the Non-Potable Water SystemThe Busted Butte Subsurface Fire Water System and Subsurface Portion of the Non-Potable Water System mitigates hazards commonly associated with the tunneling/mining industry; these hazards are not unique to the YMP site characterization activities. The loss of the Busted Butte Subsurface Fire Water System and Subsurface Portion of the Non-Potable Water System could adversely impact the Project mission since it provides incipient fire protection underground. Therefore, the Busted Butte Subsurface Fire Water System and Subsurface Portion of the NonPotable Water System are classified as FCL3.

\subsubsection{Busted Butte Muck Storage System}

The Busted Butte Muck Storage System does not provide a safety function to the facility and does not mitigate any unique hazards associated with the YMP site characterization activities. Loss of this system would not negatively impact the Project mission. Therefore, the Busted Butte Muck Storage System is classified as FCL4. 


\subsubsection{Busted Butte Ground Support System}

The Busted Butte Ground Support System mitigates hazards commonly associated with the tunneling/mining industry; these hazards are not unique to the YMP site characterization activities. Although a complete failure of the system is highly unlikely, the loss of a portion of the ground support system (i.e., a keyblock) could negatively impact the Project mission. Therefore, Busted Butte Ground Support System is classified as FCL3.

\subsubsection{Busted Butte Sanitation System}

The Busted Butte Sanitation System does not provide a safety function to the facility and does not mitigate any unique hazards associated with the YMP site characterization activities. Loss of this system would not negatively impact the Project mission. Therefore, the Busted Butte Sanitation System is classified as FCL4.

\subsubsection{Busted Butte Subsurface Lighting System}

The hazards associated with the Busted Butte Subsurface Lighting System are common to the tunneling/mining industry; these hazards are not unique to the YMP site characterization activities. The loss of the Busted Butte Subsurface Lighting System would not present a lifethreatening situation or negatively impact the Project mission since the use of personal protective equipment (i.e., a cap lamp) mitigates the hazards. Therefore, the Busted Butte Subsurface Lighting System is classified as FCL4.

\subsubsection{Busted Butte Access Road System}

The Busted Butte Access Road System does not provide a safety function to the facility and does not mitigate any unique hazards associated with the YMP site characterization activities. Loss of the Busted Butte Access Road System would not negatively impact the Project mission. Therefore, the Busted Butte Access Road System is classified as FCL4.

\subsubsection{Busted Butte Pad Drainage System}

The Busted Butte Pad Drainage System does not provide a safety function to the facility and does not mitigate any unique hazards associated with the YMP site characterization activities. The loss of this system would not negatively impact the Project mission. Therefore, the Busted Butte Pad Drainage System is classified as FCL4.

\subsubsection{Busted Butte Security System}

The Busted Butte Security System provides protection from unauthorized access to the facility and does not mitigate any unique hazards associated with the YMP site characterization activities. The loss of this system would not negatively impact the Project mission. Therefore, the Busted Butte Security System is classified as FCL4. 


\subsubsection{Busted Butte Topsoil/Rock Storage}

Busted Butte Topsoil/Rock Storage does not provide a safety function to the facility and does not mitigate any unique hazards associated with the YMP site characterization activities. A loss of this system would not negatively impact the Project mission. Therefore, Busted Butte Topsoil/Rock Storage is classified as FCL4.

\subsubsection{Busted Butte Data Acquisition System}

Busted Butte Data Acquisition does not provide a safety function to the facility and does not mitigate any unique hazards associated with the YMP site characterization activities. However, the loss of Data Acquisition could negatively impact the Project mission. Thus, Data Acquisition is classified as FCL3.

\subsubsection{Busted Butte Parking Areas}

The Busted Butte Parking Areas do not provide a safety function to the facility and do not mitigate any unique hazards associated with the YMP site characterization activities. A loss of the Busted Butte Parking Areas would not negatively impact the Project mission. Thus, the Busted Butte Parking Areas are classified as FCL4.

\subsubsection{Busted Butte Operations Building}

The Busted Butte Operations Building (two small trailers at Busted Butte) does not provide a safety function to the facility and does not mitigate any unique hazards associated with the YMP site characterization activities. A loss of the Busted Butte Operations Building would not negatively impact the Project mission. Therefore, the Busted Butte Operations Building is classified as FCLA.

\subsubsection{North Las Vegas Test Facility Classification}

Tests are being performed in leased facilities that are maintained by the building owner. There are two buildings that comprise this facility: a laboratory facility in Building B-4 and a Low Bay facility in Building A-1. The North Las Vegas Test Facility systems identified in Section 2 are classified in the following subsections using the Functional Classification criteria identified in Section 5.1.1. The results of these classifications are summarized in Table 5-3 and in the subsections that follow.

Table 5-3. Functional Classification of North Las Vegas Test Facility Systems

\begin{tabular}{|l|c|l|}
\hline \multicolumn{1}{|c|}{ SYSTEM DESCRIPTION } & $\begin{array}{c}\text { Functional } \\
\text { Classification }\end{array}$ & \multicolumn{1}{c|}{ SAFETY ENVELOPE } \\
\hline Building B-4 & FCL4 & N/A \\
\hline Building A-1 & FCL4 & N/A \\
\hline
\end{tabular}

N/A Not Applicable 


\subsubsection{Building B-4}

The tests being performed in Building B-4 are on material samples and are relatively small (counter top) size tests, typical of a civil/mechanical engineering laboratory. There is no large equipment or machinery. The testing activities are common to the industry and are consistent with the intended use of the facility. Failure of any of these tests will not cause the facility to shut down or impact the other tests being performed in Building B-4. No special monitoring of the facility is required by the tests that are performed in this building. Therefore Building B-4 is classified at a level of FCL4.

\subsubsection{Building A-1}

A test to measure the effectiveness of drift ventilation is being set up in this Low Bay building. The major components of this test are made up of steel, concrete, and crushed tuff. The Low Bay has overhead cranes that are used to set up the test, but are not used for the test. The maintenance and operations of these cranes is the responsibility of the building owner. This is the only test in this building and it is consistent with the intended use of the Low Bay building. Any failures associated with this test are not anticipated to shut down the building. There are no other tests in this building to impact. Therefore the Building A-1 Low Bay is classified at a level of FCL4.

\subsubsection{Other Area 25 Support Facilities}

The other Area 25 support facility systems identified in Section 2 are classified in the following subsections using the Functional Classification criteria identified in Section 5.1.1. The results of these classifications are summarized in Table 5-4 and in the subsections that follow.

Table 5-4. Functional Classification of the Other Area 25 Support Facility Systems

\begin{tabular}{|l|c|l|}
\hline \multicolumn{1}{|c|}{ SYSTEM DESCRIPTION } & $\begin{array}{c}\text { Functional } \\
\text { Classification }\end{array}$ & \multicolumn{1}{|c|}{ SAFETY ENVELOPE } \\
\hline Batch Plant & FCL4 & N/A \\
\hline Borrow Pit & FCL4 & N/A \\
\hline Lower Muck Storage Area & FCL4 & N/A \\
\hline Subdock & FCL4 & N/A \\
\hline $\begin{array}{l}\text { Non-Hazardous Waste Management } \\
\text { Area }\end{array}$ & FCL4 & N/A \\
\hline Terrestrial Ecosystems Storage Yard & FCL4 & N/A \\
\hline Fran Ridge & FCL4 & N/A \\
\hline Boreholes & FCL4 & N/A \\
\hline Heliports & FCL4 & N/A \\
\hline Access Roads & FCL4 & N/A \\
\hline Meteorological Tower Complex & FCL4 & N/A \\
\hline Gas Station & FCL4 & N/A \\
\hline
\end{tabular}


Table 5-4. Functional Classification of the Other Area 25 Support Facility Systems (Continued)

\begin{tabular}{|l|c|l|}
\hline \multicolumn{1}{|c|}{ SYSTEM DESCRIPTION } & $\begin{array}{c}\text { Functional } \\
\text { Classification }\end{array}$ & \multicolumn{1}{|c|}{ SAFETY ENVELOPE } \\
\hline Mine Rescue & FCL4 & N/A \\
\hline UNR Seismic Studies & FCL4 & N/A \\
\hline Control Support Area & FCL4 & \\
\hline N/A Not Applicable
\end{tabular}

\subsubsection{Batch Plant}

The Batch Plant does not provide a safety function at the YMP and does not mitigate any unique hazards associated with the YMP site characterization activities. A loss of the Batch Plant would not negatively impact the Project mission. Thus, the Batch Plant is classified as FCL4.

\subsubsection{Borrow Pit}

The Borrow Pit does not provide a safety function at the YMP and does not mitigate any unique hazards associated with the YMP site characterization activities. A loss of the Borrow Pit would not negatively impact the Project mission. Thus, the Borrow Pit is classified as FCL4.

\subsubsection{Lower Muck Storage Area}

The Lower Muck Storage Area does not provide a safety function at the YMP and does not mitigate any unique hazards associated with the YMP site characterization activities. A loss of the Lower Muck Storage Area would not negatively impact the Project mission. Thus, the Lower Muck Storage Area is classified as FCL4.

\subsubsection{Subdock}

The Subdock does not provide a safety function at the YMP and does not mitigate any unique hazards associated with the YMP site characterization activities. A loss of the Subdock would not negatively impact the Project mission. Thus, the Subdock is classified as FCL4.

\subsubsection{NWMA}

The NWMA does not provide a safety function at the YMP and does not mitigate any unique hazards associated with the YMP site characterization activities. A loss of the NWMA would not negatively impact the Project mission. Thus, the NWMA is classified as FCL4.

\subsubsection{Terrestrial Ecosystems Storage Yard}

The Terrestrial Ecosystems Storage Yard does not provide a safety function at the YMP and does not mitigate any unique hazards associated with the YMP site characterization activities. A loss of the use of the Terrestrial Ecosystems Storage Yard would not negatively impact the Project mission. Thus, the Terrestrial Ecosystems Storage Yard is classified as FCL4. 


\subsubsection{Fran Ridge}

Fran Ridge is currently closed; therefore, it does not provide a safety function at the YMP and does not mitigate any unique hazards associated with the YMP site characterization activities. Thus, Fran Ridge is classified as FCL4.

\subsubsection{Boreholes}

The boreholes do not provide a safety function at the YMP and do not mitigate any unique hazards associated with the YMP site characterization activities. A loss of the use of the boreholes would not negatively impact the Project mission. Thus, the boreholes are classified as FCL4.

\subsubsection{Heliports}

The Heliports do not provide a safety function at the YMP and do not mitigate any unique hazards associated with the YMP site characterization activities. A loss of the use of the Heliports would not negatively impact the Project mission. Thus, the Heliports are classified as FCL4.

\subsubsection{Access Roads}

The Access Roads do not provide a safety function at the YMP and do not mitigate any unique hazards associated with the YMP site characterization activities. A loss of the use of the Access Roads would not negatively impact the Project mission. Thus, the Access Roads are classified as FCL4.

\subsubsection{Meteorological Tower Complex}

The Meteorological Tower Complex does not provide a safety function at the YMP and does not mitigate any unique hazards associated with the YMP site characterization activities. Subsequent precipitation events (such as 1 inch of rain in 24 hours) at this site are reported through the Determination of Importance Evaluation process for surface-based testing activities. A loss of the use of the Meteorological Tower Complex would not negatively impact the Project mission. Thus, the Meteorological Tower Complex is classified as FCL4.

\subsubsection{Gas Station}

The Gas Station utilizes an industry standard system of storing and dispensing gasoline for vehicles that are utilized at Area 25. Gasoline is not directly used in the process of site characterization. A loss of the use of the Gas Station would not negatively impact the Project mission. Thus, the Gas Station is classified as FCL4.

\subsubsection{Mine Rescue}

The Mine Rescue Facility is used for maintenance and storage of YMP mine rescue equipment and training of mine rescue personnel. This facility is a backup for the Mine Rescue Facility in the North Portal Change House and a loss of use of this Mine Rescue Facility would not 
negatively impact the ability to continue operations in the ESF and Busted Butte. Thus, the Mine Rescue Facility is classified as FCL4.

\subsubsection{UNR Seismic Studies}

The UNR Seismic Studies Facility does not provide a safety function at the YMP and does not mitigate any unique hazards associated with the YMP site characterization activities. A loss of the use of the UNR Seismic Studies Facility would not negatively impact the Project mission. Thus, the UNR Seismic Studies Facility is classified as FCL4.

\subsubsection{Central Support Area}

The Sample Management Facility, the Hydrologic Research Facility, and the Site Maintenance Building, which comprise the Central Support Area, are all classified as FCL4. These facilities do not provide a safety function at the YMP and do not mitigate any unique hazards associated with the YMP site characterization activities. A loss of the use of these facilities that comprise the Central Support Area would not negatively impact the Project mission. Thus, the Central Support Area is classified as FCL4.

\subsubsection{Offices, Science Centers, and Warehouse Facilities}

The offices, science centers, and warehouse all occupy leased facilities that meet all applicable building codes and standards. These uses of leased facilities all are consistent with the intended purpose of each respective building. It is the conclusion of this Safety Basis Report that these type of leased buildings, used for these types of functions (office space, science center and warehouse), are exempt from functional classification in this Safety Basis. Changes to the internal configuration of these facilities will not impact the Project mission and will always be controlled by the owner of the buildings.

\subsection{OPERATING PARAMETERS}

There are no ESF, Busted Butte, North Las Vegas, or other Area 25 support facility systems classified as FCL1 or FCL2, so there are no operating parameters that need to be defined to establish the minimum safety envelope necessary for the critical operation of any systems.

\subsection{DEFINITIONS}

Common Industrial Hazards-Hazards routinely encountered by the general public or in general industry and construction, and for which national consensus codes and/or standards exist 
to guide safe design and operation without the need for special analysis to define safety design and/or operational parameters.

Fatal Injury-In this instance, a Fatal Injury is defined as any injury that results in death within 30 calendar days of the accident.

Minor Injury-Any injury which:

- Requires hospitalization for less than 48 hours, commencing within seven days from the date the injury was received

- Results in only a simple fracture of fingers, toes, or nose

- Does not cause severe hemorrhages, nerve, muscle, or tendon damage

- Does not involves any internal organ

- Does not involve second- or third-degree burns, or any burns affecting more than 5 percent of the body surface.

Serious Injury-Any injury which:

- Requires hospitalization for more than 48 hours, commencing within seven days from the date the injury was received

- Results in a fracture of any bone (except simple fractures of fingers, toes, or nose)

- Causes severe hemorrhages, nerve, muscle, or tendon damage

- Involves any internal organ

- Involves second- or third-degree burns, or any burns affecting more than 5 percent of the body surface.

Public-For the purposes of Functional Classification, the public is considered to be individuals located at or beyond the site boundary.

Worker-Persons located within the confines of the site boundary; this term includes facility workers, collocated workers, contractors, subcontractors, employees, and visitors.

Visitors-Individuals who have not received General Underground Training and are not afforded unescorted access to the ESF.

Emergency Response Planning Guidelines (ERPG)-Airborne concentrations established by the American Industrial Hygienists Association for the use in emergency planning (AIHA 1998). 
ERPG-1: the maximum concentration in air below which it is believed nearly all individuals could be exposed for up to one hour without experiencing other than mild transient adverse health effects or perceiving a clearly defined objectionable odor.

ERPG-2: the maximum concentration in air below which it is believed nearly all individuals could be exposed for one hour without experiencing or developing irreversible or other serious health effects or symptoms that could impair their abilities to take protective action.

ERPG-3: the maximum concentration in air below which it is believed nearly all individuals could be exposed for up to one hour without experiencing or developing life-threatening health effects. 
INTENTIONALLY LEFT BLANK 


\section{SAFETY BASIS MANAGEMENT}

The management of changes to the Safety Basis for YMP site characterization activities, as established in this report, supports the continuous improvement function of the Integrated Safety Management process by providing a means of changing and updating the Safety Basis as the ESF matures. Configuration control of the Safety Basis is maintained via the Safety Basis management process. The Safety Basis management process is an integral part of the design process, the design control process, and hazard analysis. The objective of the Safety Basis management process is to evaluate and control changes that could potentially:

- Increase the risk from a hazard to the workers and/or the public beyond that previously analyzed, evaluated, and documented in the current document

- Reduce the reliability or effectiveness of features, controls, procedures, or processes that mitigate hazards

- Introduce a new hazard

- Reflect new information on existing hazards beyond that currently documented

Personnel who have received training on the Safety Basis management process would perform an evaluation of changes to the Safety Basis against the above-cited criteria.

When a proposal is made to modify or change any ESF system, the proposed design change requires an evaluation to determine if there exist any potential impacts to the Safety Basis. This evaluation must determine if a change is to be made to the Safety Basis or if the proposed design change should be altered such that the Safety Basis is not compromised. If the Safety Basis is to be changed, a formal process is provided through the Management of Safety Basis Change Process procedure (AP-ENG-001).

The Management of Safety Basis Change Process procedure is integrated into the design control and work control processes in accordance with the Hazards Analysis System procedure (APESH-008). The Hazards Analysis System procedure directs the use of the Management of Safety Basis Change Process procedure to ensure that design changes and work activities are evaluated for impacts to the Safety Basis. 
INTENTIONALLY LEFT BLANK 


\section{REFERENCES}

\subsection{DOCUMENTS CITED}

AIHA 1998. Emergency Response Planning Guidelines and Workplace Environmental Exposure Level Guides Handbook. Fairfax, Virginia: AIHA Press.

BSC (Bechtel SAIC Company) 2001a. ECRB Refuge Chamber. BABEAF000-01717-021000011 REV 00. Las Vegas, Nevada: Bechtel SAIC Company.

BSC 2001b. ECRB Refuge Station General Arrangement and Details. BABEAF000-017172100-40361 REV 00 DCN01. Las Vegas, Nevada: Bechtel SAIC Company.

BSC 2001c. Determination, Decision, or Directive Documentation. DF: 02-0013. Las Vegas, Nevada: Bechtel SAIC Company.

BSC 2001d. System Safety Analysis for Fire Events Associated with the ECRB Cross Drift. BAB000000-01717-0200-00150 REV 00. Las Vegas, Nevada: Bechtel SAIC Company.

CRWMS M\&O 1999. Construction Monitoring in the Exploratory Studies Facility. Field Work Package FWP-ESF-96-002, Rev. 4. Las Vegas, Nevada: CRWMS M\&O. ACC: MOL.19990811.0078.

CRWMS M\&O [Civilian Radioactive Waste Management System Management and Operating Contractor] 2000. Sealed Source and Radioactive Material Inventory. Report Date: 06/15/2000. Las Vegas, Nevada: CRWMS M\&O. ACC: MOL.20000628.0129.

DOE [U.S. Department of Energy] 2000. Quality Assurance Requirements and Description. DOE/RW-0333P, Rev. 10. Washington, D.C.: U.S. Department of Energy, Office of Civilian Radioactive Waste Management. ACC: MOL.20000427.0422.

Dyer, J.R. 1998. “Technical Direction - Exploratory Study Facility Site Characterization Design and Installation Base Code Compliance". Letter from J.R. Dyer (DOE/YMSCO) to D.R. Wilkins (CRWMS M\&O), April 02, 1998. ACC: MOL.19980902.0316.

Gwyn, D.W. 1999a. "QAP-2-0 Evaluations." Interoffice Correspondence from D.W. Gwyn (CRWMS M\&O) to R.A. Morgan, October 18, 1999, LV.SA.DWG.10/99-093, with attachment. ACC: MOL.19991105.0076

Gwyn, D.W. 1999b. "System Safety Evaluation of Title III Evaluation Reports Recommended Work." Interoffice Correspondence from D.W. Gwyn (CRWMS M\&O) to W. Kennedy, August 11, 1999, LV.SA.WWP.08/99-077, with attachment. ACC: MOL.19990830.0320; MOL.19990830.0321

Miles, J.B. 1998. "Applicability of PSM Standard to Explosive and Pyrotechnic Manufacturing." Letter from J.B. Miles (Occupational Safety and Health Administration) to F.A. White, February 4, 1998. Washington, D.C.: U. S. Department of Labor, Occupational Safety and Health Administration. ACC: MOL.20000620.0070. 
Parker, C.W. 1996. "Exploratory Studies Facility (ESF) Tunnel "Air Bubble" Concept." Letter from C.W. Parker (CRWMS M\&O) to W.R. Dixon (DOE/YMSCO), August 22, 1996, LV.MOSH.CWP.08/96-102. ACC: MOL.19961211.0129.

Perry, R.H. and Chilton, C.H. 1973. Chemical Engineers' Handbook. $5^{\text {th }}$ Edition. New York, New York: McGraw Hill. TIC: 237826.

USBM (U.S. Bureau of Mines) 1983. Development of Guidelines for Rescue Chambers, Volume I. BM-7836. Washington, DC. U.S. Bureau of Mines, U.S. Department of the Interior.

Weast, R.C., ed. 1972. CRC Handbook of Chemistry and Physics. 53rd Edition. Cleveland, Ohio: Chemical Rubber Company. TIC: 219220. 
YMP [Yucca Mountain Site Characterization Project] 1997. Exploratory Studies Facility Design Requirements. YMP/CM-0019, Rev. 2, ICN 1. Las Vegas, Nevada: Yucca Mountain Site Characterization Office. ACC: MOL.19980107.0544; MOL.19960926.0065.

\subsection{CODES, STANDARDS, AND PROCEDURES}

10 CFR 30, Energy: Rules of General Applicability to Domestic Licensing of Byproduct Material. Readily available.

29 CFR 1910, Labor: Occupational Safety and Health Standards. Readily available.

29 CFR 1926, Labor: Safety and Health Regulations for Construction. Readily available.

40 CFR 68, Protection of Environment: Chemical Accident Prevention Provisions. Readily available.

40 CFR 302, Protection of Environment: Designation, Reportable Quantities, and Notification Readily available.

40 CFR 355, Protection of Environment: Emergency Planning and Notification. Readily available.

ANSI/ANS-8.1-1983. Nuclear Criticality Safety in Operations with Fissionable Materials Outside Reactors. La Grange Park, Illinois: American Nuclear Society. TIC: 231616.

AP-ENG-001, Rev. 0, ICN 0. Management of Safety Basis Change Process. Washington, D.C.: U.S. Department of Energy, Office of Civilian Radioactive Waste Management. ACC: MOL.20000627.0261

AP-ESH-008, Rev. 0, ICN 0. Hazards Analysis System. Washington, D.C.: U.S. Department of Energy, Office of Civilian Radioactive Waste Management. ACC: MOL.20000705.0094

DOE-EM-STD-5502-94. 1994. Hazard Baseline Documentation. Washington, D.C.: U.S. Department of Energy. Readily Available.

DOE Order 5480.19. 1992. Conduct of Operations Requirements for DOE Facilities. Washington, D.C.: U.S. Department of Energy. Readily available.

DOE Order 5480.23. 1992. Nuclear Safety Analysis Reports. Washington, D.C.: U.S. Department of Energy. Readily available.

DOE-STD-1027-92. 1997. Hazard Categorization and Accident Analysis Techniques for Compliance with DOE Order 5480.23, Nuclear Safety Analysis Reports. Washington, D.C.: U.S. Department of Energy. Readily Available.

LP-ESH-010-M\&O, Rev. 0, ICN 0. Emergency Management. Washington, D.C.: U.S. Department of Energy, Office of Civilian Radioactive Waste Management. ACC: MOL.20000620.0070. 
APPENDIX A

EVALUATION OF HAZARDOUS MATERIALS INVENTORIES 
INTENTIONALLY LEFT BLANK 


\section{APPENDIX A}

\section{EVALUATION OF HAZARDOUS MATERIALS INVENTORIES}

Table A-1. Comparison of Radiological Potentially Releasable Quantities from Unsealed Sources to DOE-STE-1027-92 Category 3 Radionuclide Thresholds

\begin{tabular}{|c|c|c|c|c|c|}
\hline Nuclide $^{1}$ & $\begin{array}{c}\text { Current } \\
\text { Activity } \\
(\mathrm{uCi})^{2}\end{array}$ & $\begin{array}{c}\text { Current } \\
\text { Activity }(\mathrm{C} i)\end{array}$ & $\begin{array}{c}\text { Category } 3 \\
\text { Threshold } \\
\text { (Ci) }^{3}\end{array}$ & $\begin{array}{l}\text { Ratio to } \\
\text { Category } 3 \\
\text { Threshold }\end{array}$ & Hazard Class \\
\hline Po-210 & $3.94 \mathrm{E}-08$ & $3.94 \mathrm{E}-14$ & $1.90 \mathrm{E}+00$ & $2.07 E-14$ & Less Than Hazard Category 3 \\
\hline Sr-90 & $8.26 E-02$ & $8.26 \mathrm{E}-08$ & $1.60 E+01$ & 5.16E-09 & Less Than Hazard Category 3 \\
\hline $\mathrm{Ra}-226$ & $6.06 \mathrm{E}+00$ & $6.06 \mathrm{E}-06$ & $N / L$ & N/A & N/A \\
\hline $\mathrm{Ra}-226$ & $6.05 \mathrm{E}+00$ & $6.05 \mathrm{E}-06$ & $N / L$ & N/A & N/A \\
\hline $\begin{array}{l}\text { Am-241+mixed } \\
\text { gamma }\end{array}$ & $5.23 \mathrm{E}+00$ & 5.23E-06 & $5.20 \mathrm{E}-01$ & $1.01 E-05$ & Less Than Hazard Category 3 \\
\hline $\mathrm{C}-14 / \mathrm{H}-3$ & $1.75 \mathrm{E}-01$ & $1.75 \mathrm{E}-07$ & $4.20 \mathrm{E}+02$ & 4.17E-10 & Less Than Hazard Category 3 \\
\hline $\mathrm{C}-14 / \mathrm{H}-3$ & $5.94 \mathrm{E}-02$ & $5.94 \mathrm{E}-08$ & $4.20 \mathrm{E}+02$ & $1.41 \mathrm{E}-10$ & Less Than Hazard Category 3 \\
\hline C-14 & $5.41 E-02$ & $5.41 \mathrm{E}-08$ & $4.20 \mathrm{E}+02$ & $1.29 \mathrm{E}-10$ & Less Than Hazard Category 3 \\
\hline $\mathrm{H}-3$ & $6.70 \mathrm{E}-02$ & $6.70 \mathrm{E}-08$ & $1.60 \mathrm{E}+04$ & 4.19E-12 & Less Than Hazard Category 3 \\
\hline $\mathrm{Pu}-239$ & $2.00 \mathrm{E}-03$ & 2.00E-09 & $5.20 \mathrm{E}-01$ & $3.85 E-09$ & Less Than Hazard Category 3 \\
\hline $\mathrm{Ra}-226$ & $1.00 \mathrm{E}-03$ & $1.00 \mathrm{E}-09$ & $N / L$ & N/A & N/A \\
\hline U-238,235,234 & $4.00 \mathrm{E}-04$ & 4.00E-10 & $4.20 E+00$ & $9.52 E-11$ & Less Than Hazard Category 3 \\
\hline Po-210 & 2.72E-03 & $2.72 E-09$ & $1.90 \mathrm{E}+00$ & $1.43 E-09$ & Less Than Hazard Category 3 \\
\hline$U-235$ & $2.00 \mathrm{E}-03$ & $2.00 \mathrm{E}-09$ & $4.20 E+00$ & $4.76 \mathrm{E}-10$ & Less Than Hazard Category 3 \\
\hline Am-241 & 1.97E-03 & 1.97E-09 & $5.20 \mathrm{E}-01$ & $3.79 E-09$ & Less Than Hazard Category 3 \\
\hline Ra-226 & $2.49 E-03$ & $2.49 \mathrm{E}-09$ & $N / L$ & N/A & N/A \\
\hline $\mathrm{C}-14 / \mathrm{H}-3$ & $5.49 \mathrm{E}-01$ & 5.49E-07 & $4.20 E+02$ & $1.31 E-09$ & Less Than Hazard Category 3 \\
\hline Ra-226 & 8.10E-05 & $8.10 \mathrm{E}-11$ & $\mathrm{~N} / \mathrm{L}$ & N/A & N/A \\
\hline $\mathrm{Ra}-226$ & $1.50 \mathrm{E}-02$ & $1.50 \mathrm{E}-08$ & $N / L$ & N/A & N/A \\
\hline $\mathrm{H}-3$ & $6.37 \mathrm{E}-02$ & $6.37 E-08$ & $1.60 \mathrm{E}+04$ & $3.98 \mathrm{E}-12$ & Less Than Hazard Category 3 \\
\hline C-14 & $6.12 \mathrm{E}-02$ & $6.12 \mathrm{E}-08$ & $4.20 E+02$ & $1.46 \mathrm{E}-10$ & Less Than Hazard Category 3 \\
\hline U-238,235,234 & $1.28 \mathrm{E}+01$ & $1.28 \mathrm{E}-05$ & $4.20 E+02$ & $3.05 E-08$ & Less Than Hazard Category 3 \\
\hline $\begin{array}{l}\text { Cs-137 (note: } \\
\text { powder) }\end{array}$ & $6.57 \mathrm{E}-03$ & $6.57 \mathrm{E}-09$ & $6.00 \mathrm{E}+01$ & $1.10 \mathrm{E}-10$ & Less Than Hazard Category 3 \\
\hline \multicolumn{4}{|c|}{ Sum of Ratios $=$} & 1.01E-05 & Other Industrial \\
\hline
\end{tabular}

${ }^{1}$ From liquid sources, unless otherwise noted

${ }^{2}$ From the Sealed Source and Radioactive Material Inventory

${ }^{3}$ As reported in DOE-STD-1027-92

N/L Not Listed; no Category 3 Threshold listed in DOE-STD-1027-92

N/A Not Applicable since no Category 3 Category is listed 
Table A-2. Comparison of Radiological Potentially Releasable Quantities from Unsealed Sources to 40 CFR 302.4 Appendix B Reportable Quantity Limits

\begin{tabular}{|c|c|c|c|c|c|c|c|}
\hline $\begin{array}{l}\text { Source } \\
\text { Serial } \\
\text { Number }\end{array}$ & Nuclide $^{1}$ & $\begin{array}{c}\text { Current } \\
\text { Activity } \\
\text { (uCi) }\end{array}$ & $\begin{array}{c}\text { Current } \\
\text { Activity } \\
\text { (Ci) }\end{array}$ & $\mathbf{R F}^{3}$ & $\begin{array}{c}\text { Potentially } \\
\text { Releasable } \\
\text { Quantity } \\
\text { (Ci) }\end{array}$ & $\begin{array}{l}40 \text { CFR } 302 \\
\text { Appendix B } \\
\text { Reportable } \\
\text { Quantity } \\
\text { (Ci) }\end{array}$ & $\begin{array}{c}\text { Criteria } \\
\text { Exceeded } \\
?\end{array}$ \\
\hline 1 & Po-210 & $3.94 E-08$ & $3.94 \mathrm{E}-14$ & $1.00 \mathrm{E}-03$ & 3.94E-17 & 0.01 & No \\
\hline \multirow[t]{2}{*}{5 of 7} & Po-210 & $2.72 \mathrm{E}-03$ & 2.72E-09 & $1.00 \mathrm{E}-03$ & $2.72 E-12$ & 0.01 & No \\
\hline & Total Po-210 & 2.72E-03 & 2.72E-09 & 1.00E-03 & 2.72E-12 & 0.01 & No \\
\hline 2 & Sr-90 & $8.26 \mathrm{E}-02$ & $8.26 \mathrm{E}-08$ & $1.00 \mathrm{E}-03$ & $8.26 \mathrm{E}-11$ & 0.1 & No \\
\hline $\mathrm{R} 9 / 50 / 62$ & Ra-226 & $6.06 \mathrm{E}+00$ & $6.06 \mathrm{E}-06$ & $1.00 \mathrm{E}-03$ & $6.06 E-09$ & 0.1 & No \\
\hline $\mathrm{R} 9 / 50 / 61$ & Ra-226 & $6.05 \mathrm{E}+00$ & $6.05 \mathrm{E}-06$ & 1.00E-03 & $6.05 \mathrm{E}-09$ & 0.1 & No \\
\hline 2 of 7 & Ra-226 & $1.00 \mathrm{E}-03$ & 1.00E-09 & $1.00 E-03$ & $1.00 \mathrm{E}-12$ & 0.1 & No \\
\hline 00102 & Ra-226 & $2.49 \mathrm{E}-03$ & 2.49E-09 & $1.00 E-03$ & $2.49 \mathrm{E}-12$ & 0.1 & No \\
\hline 4968-094 & $\mathrm{Ra}-226$ & $8.10 \mathrm{E}-05$ & $8.10 \mathrm{E}-11$ & $1.00 \mathrm{E}-03$ & $8.10 \mathrm{E}-14$ & 0.1 & No \\
\hline \multirow[t]{2}{*}{ 4968-104 } & Ra-226 & $1.50 \mathrm{E}-02$ & $1.50 \mathrm{E}-08$ & 1.00E-03 & $1.50 \mathrm{E}-11$ & 0.1 & No \\
\hline & Total Ra-226 & 1.21E+01 & 1.21E-05 & $1.00 \mathrm{E}-03$ & 1.21E-08 & 0.1 & No \\
\hline $\begin{array}{c}\mathrm{RO} / 145 / 17 \\
6\end{array}$ & $\begin{array}{l}\text { Am- } \\
241+\text { mixed } \\
\text { gamma }\end{array}$ & $5.23 E+00$ & 5.23E-06 & 1.00E-03 & 5.23E-09 & 0.01 & No \\
\hline \multirow[t]{2}{*}{7 of 7} & Am-241 & 1.97E-03 & $1.97 E-09$ & 1.00E-03 & $1.97 \mathrm{E}-12$ & 0.01 & No \\
\hline & $\begin{array}{l}\text { Total Am- } \\
241\end{array}$ & $5.23 E+00$ & 5.23E-06 & $1.00 \mathrm{E}-03$ & 5.23E-09 & 0.01 & No \\
\hline $131-213$ & $\mathrm{C}-14 / \mathrm{H}-3$ & $1.75 \mathrm{E}-01$ & $1.75 \mathrm{E}-07$ & $1.00 \mathrm{E}-03$ & $1.75 \mathrm{E}-10$ & $10.0 / 100.0$ & No \\
\hline $110-110$ & $\mathrm{C}-14 / \mathrm{H}-3$ & $5.94 \mathrm{E}-02$ & $5.94 \mathrm{E}-08$ & $1.00 \mathrm{E}-03$ & $5.94 \mathrm{E}-11$ & $10.0 / 100.0$ & No \\
\hline$\# 3$ & $\mathrm{C}-14 / \mathrm{H}-3$ & 5.49E-01 & $5.49 \mathrm{E}-07$ & $1.00 E-03$ & $5.49 \mathrm{E}-10$ & $10.0 / 100.0$ & No \\
\hline 00019 & C-14 & $5.41 \mathrm{E}-02$ & $5.41 \mathrm{E}-08$ & $1.00 \mathrm{E}-03$ & $5.41 \mathrm{E}-11$ & 10.0 & No \\
\hline \multirow[t]{2}{*}{$\mathrm{B}$} & C-14 & $6.12 \mathrm{E}-02$ & $6.12 \mathrm{E}-08$ & $1.00 \mathrm{E}-03$ & $6.12 \mathrm{E}-11$ & 10.0 & No \\
\hline & Total C-14 & 8.99E-01 & 8.99E-07 & 1.00E-03 & 8.99E-10 & 10.0 & No \\
\hline $00-001$ & $\mathrm{H}-3$ & $6.70 \mathrm{E}-02$ & $6.70 \mathrm{E}-08$ & $1.00 \mathrm{E}-03$ & 6.70E-11 & 100.0 & No \\
\hline \multirow[t]{2}{*}{$A$} & $\mathrm{H}-3$ & $6.37 \mathrm{E}-02$ & $6.37 \mathrm{E}-08$ & $1.00 \mathrm{E}-03$ & $6.37 \mathrm{E}-11$ & 100.0 & No \\
\hline & Total H-3 & 1.31E-01 & 1.31E-07 & $1.00 \mathrm{E}-03$ & 1.31E-10 & 100.0 & No \\
\hline 1 of 7 & $\mathrm{Pu}-239$ & $2.00 \mathrm{E}-03$ & 2.00E-09 & $1.00 \mathrm{E}-03$ & $2.00 \mathrm{E}-12$ & 0.01 & No \\
\hline 3 of 7 & $\begin{array}{l}\text { U-238, } 235 \\
234\end{array}$ & 4.00E-04 & $4.00 E-10$ & $1.00 \mathrm{E}-03$ & $4.00 E-13$ & 0.1 & No \\
\hline 6 of 7 & U-235 & $2.00 \mathrm{E}-03$ & $2.00 \mathrm{E}-09$ & $1.00 \mathrm{E}-03$ & $2.00 \mathrm{E}-12$ & 0.1 & No \\
\hline N/A & $\begin{array}{l}\text { U-238, } 235 \\
234\end{array}$ & $1.28 \mathrm{E}+01$ & $1.28 \mathrm{E}-05$ & $1.00 \mathrm{E}-03$ & $1.28 \mathrm{E}-08$ & 0.1 & No \\
\hline N/A & $\begin{array}{l}\text { Cs-137 } \\
\text { (NOTE: } \\
\text { powder) }\end{array}$ & $6.57 \mathrm{E}-03$ & 6.57E-09 & $1.00 \mathrm{E}-03$ & $6.57 \mathrm{E}-12$ & 1.0 & No \\
\hline
\end{tabular}

${ }^{1}$ From liquid sources, unless otherwise noted.

${ }^{2}$ From the Sealed Source and Radioactive Material Inventory (CRWMS M\&O 2000).

${ }^{3}$ As reported in DOE-STD-1027-92. 
Table A-3. Comparison of ESF Chemical Inventory to Threshold Quantity and Threshold Planning Quantity Limits

\begin{tabular}{|c|c|c|c|c|c|c|}
\hline Location & Chemical & Inventory ${ }^{3}$ & $\begin{array}{c}29 \text { CFR } \\
1910.119 \\
\text { Threshold } \\
\text { Quantity } \\
\text { (b) }\end{array}$ & $\begin{array}{l}40 \text { CFR } 355 \\
\text { Threshold } \\
\text { Planning } \\
\text { Quantity } \\
\text { (lb) }\end{array}$ & $\begin{array}{c}40 \text { CFR } \\
68.125 \\
\text { Threshold } \\
\text { Quantity } \\
\text { (lb) }\end{array}$ & $\begin{array}{c}\text { Criteria } \\
\text { Exceeded? }\end{array}$ \\
\hline Bldg 4015 & Nitric acid & $\begin{array}{l}100 \mathrm{ml} \\
(0.33 \mathrm{lb})^{\mathrm{A}}\end{array}$ & $\begin{array}{l}500 \\
(\geq 94.5 \%)\end{array}$ & 1000 & 15,000 & No \\
\hline \multirow[t]{2}{*}{ Bldg 4221} & $\begin{array}{l}\text { Aluminum } \\
\text { oxide }\end{array}$ & $8 \mathrm{lb}$ & $\mathrm{NL}$ & $\mathrm{NL}$ & $\mathrm{NL}$ & No \\
\hline & $\begin{array}{l}\text { Isopropyl } \\
\text { alcohol }\end{array}$ & $4 \mathrm{gal}$ & $\mathrm{NL}$ & $\mathrm{NL}$ & $\mathrm{NL}$ & No \\
\hline \multirow[t]{3}{*}{ Bldg 4320} & Acetone & $\begin{array}{l}3 \mathrm{gal} \\
(19.76 \mathrm{lb})^{\mathrm{B}}\end{array}$ & $\mathrm{NL}$ & $\mathrm{NL}$ & $\mathrm{NL}$ & No \\
\hline & $\begin{array}{l}\text { Diethylene- } \\
\text { triamine }\end{array}$ & $5 \mathrm{gal}$ & $\mathrm{NL}$ & NL & NL & No \\
\hline & $\begin{array}{l}\text { Hydro- } \\
\text { chloric acid }\end{array}$ & $\begin{array}{l}7 \text { gal } \\
(69.92 \mathrm{lb})^{\mathrm{C}}\end{array}$ & 5000 & $\mathrm{NL}$ & 5000 & No \\
\hline \multirow[t]{9}{*}{ Busted Butte } & $\begin{array}{l}\text { Sodium } \\
\text { fluoride }\end{array}$ & $\begin{array}{l}15 \mathrm{~g} \\
(3.31 \mathrm{E}-02 \mathrm{lb})\end{array}$ & NL & $\mathrm{NL}$ & $\mathrm{NL}$ & No \\
\hline & $\begin{array}{l}\text { Cobalt } \\
\text { chloride } \\
\text { hexahydrate }\end{array}$ & $\begin{array}{l}2 \mathrm{~kg} \\
(4.41 \mathrm{lb})\end{array}$ & $\mathrm{NL}$ & NL & NL & No \\
\hline & $\begin{array}{l}\text { Sodium } \\
\text { sulfate }\end{array}$ & $\begin{array}{l}500 \mathrm{~g} \\
(1.10 \mathrm{lb}) \\
\end{array}$ & $\mathrm{NL}$ & $\mathrm{NL}$ & $\mathrm{NL}$ & No \\
\hline & $\begin{array}{l}\text { Magnesium } \\
\text { sulfate }\end{array}$ & $\begin{array}{l}1000 \mathrm{~g} \\
(2.20 \mathrm{lb}) \\
\end{array}$ & $\mathrm{NL}$ & $\mathrm{NL}$ & $\mathrm{NL}$ & No \\
\hline & $\begin{array}{l}\text { Sodium } \\
\text { bicarbonate }\end{array}$ & $\begin{array}{l}1000 \mathrm{~g} \\
(2.20 \mathrm{lb}) \\
\end{array}$ & $\mathrm{NL}$ & $\mathrm{NL}$ & NL & No \\
\hline & $\begin{array}{l}\text { Potassium } \\
\text { bicarbonate }\end{array}$ & $\begin{array}{l}500 \mathrm{~g} \\
(1.10 \mathrm{lb})\end{array}$ & $\mathrm{NL}$ & $\mathrm{NL}$ & $\mathrm{NL}$ & No \\
\hline & $\begin{array}{l}\text { Calcium } \\
\text { chloride }\end{array}$ & $\begin{array}{l}1000 \mathrm{~g} \\
(2.20 \mathrm{lb})\end{array}$ & $\mathrm{NL}$ & $\mathrm{NL}$ & $\mathrm{NL}$ & No \\
\hline & $\begin{array}{l}\text { Calcium } \\
\text { nitrate }\end{array}$ & $\begin{array}{l}500 \mathrm{~g} \\
(1.10 \mathrm{lb})\end{array}$ & NL & $\mathrm{NL}$ & NL & No \\
\hline & $\begin{array}{l}\text { Calcium } \\
\text { hydroxide }\end{array}$ & $\begin{array}{l}500 \mathrm{~g} \\
(1.10 \mathrm{lb})\end{array}$ & $\mathrm{NL}$ & $\mathrm{NL}$ & $\mathrm{NL}$ & No \\
\hline \multirow[t]{5}{*}{$\begin{array}{l}\text { C Well } \\
\text { Complex }\end{array}$} & Acetonitrile & $\begin{array}{l}41 \\
(6.92 \mathrm{lb})^{\mathrm{D}}\end{array}$ & $\mathrm{NL}$ & $\mathrm{NL}$ & $\mathrm{NL}$ & No \\
\hline & Methanol & 41 & $\mathrm{NL}$ & $\mathrm{NL}$ & $\mathrm{NL}$ & No \\
\hline & $\begin{array}{l}\text { Phosphoric } \\
\text { acid }\end{array}$ & $\begin{array}{l}500 \mathrm{ml} \\
(2.06 \mathrm{lb})^{E}\end{array}$ & NL & $\mathrm{NL}$ & NL & No \\
\hline & Helium & 4 cylinders & $\mathrm{NL}$ & $\mathrm{NL}$ & $\mathrm{NL}$ & No \\
\hline & $\begin{array}{l}\text { Sodium } \\
\text { Hydroxide }\end{array}$ & $\begin{array}{l}3 \mathrm{~kg} \\
(1.36 \mathrm{lb})\end{array}$ & $\mathrm{NL}$ & $\mathrm{NL}$ & $\mathrm{NL}$ & No \\
\hline
\end{tabular}


Table A-3. Comparison of ESF Chemical Inventory to Threshold Quantity and Threshold Planning Quantity Limits (Continued)

\begin{tabular}{|c|c|c|c|c|c|c|}
\hline Location & Chemical & Inventory ${ }^{1}$ & $\begin{array}{c}29 \text { CFR } \\
1910.119 \\
\text { Threshold } \\
\text { Quantity } \\
\text { (lb) }\end{array}$ & $\begin{array}{l}\text { 40 CFR } 355 \\
\text { Threshold } \\
\text { Planning } \\
\text { Quantity } \\
\text { (lb) }\end{array}$ & $\begin{array}{c}\text { 40 CFR } \\
68.125 \\
\text { Threshold } \\
\text { Quantity } \\
\text { (lb) }\end{array}$ & $\begin{array}{c}\text { Criteria } \\
\text { Exceeded? }\end{array}$ \\
\hline $\begin{array}{l}\text { Cabinet } \\
\text { Outside Bldg } \\
4215\end{array}$ & $\begin{array}{l}\text { Isopropy| } \\
\text { alcohol }\end{array}$ & $1 \mathrm{gal}$ & NL & NL & NL & No \\
\hline \multirow[t]{2}{*}{$\begin{array}{l}\text { Calibration } \\
\text { Lab Bldg } \\
4215\end{array}$} & Mercury & $\begin{array}{l}5 \mathrm{~g} \\
(0.01 \mathrm{lb})\end{array}$ & $\mathrm{NL}$ & NL & $\mathrm{NL}$ & No \\
\hline & $\begin{array}{l}\text { Sodium } \\
\text { chloride }\end{array}$ & $1 \mathrm{~kg}$ & NL & NL & NL & No \\
\hline \multirow[t]{2}{*}{$\begin{array}{l}\text { Drilling } \\
\text { Subdock }\end{array}$} & Acetylene & $\begin{array}{l}250 \mathrm{ft}^{3} \\
(17.01 \mathrm{lb})^{F}\end{array}$ & $\mathrm{NL}$ & NL & 10,000 & No \\
\hline & $\begin{array}{l}\text { Sulfur } \\
\text { hexafluoride }\end{array}$ & $2200 \mathrm{ft}^{3}$ & $\mathrm{NL}$ & NL & NL & No \\
\hline \multirow[t]{4}{*}{ ESF } & $\begin{array}{l}\text { Lithium } \\
\text { bromide }\end{array}$ & $159.44 \mathrm{~kg}$ & NL & $\mathrm{NL}$ & NL & No \\
\hline & $\begin{array}{l}\text { Carbon } \\
\text { monoxide }\end{array}$ & $60 \mathrm{ft}^{3}$ & NL & NL & NL & No \\
\hline & Ethanol & $8 \mathrm{oz}$ & $\mathrm{NL}$ & $\mathrm{NL}$ & $\mathrm{NL}$ & No \\
\hline & $\begin{array}{l}\text { Aluminum } \\
\text { oxide }\end{array}$ & $4 \mathrm{lb}$ & NL & $N L$ & $\mathrm{NL}$ & No \\
\hline \multirow[t]{11}{*}{$\begin{array}{l}\text { ESF Pad/ } \\
\text { Busted Butte } \\
\text { Pad }\end{array}$} & $\begin{array}{l}2,3,4,5 \text { tetra } \\
\text { fluoro- } \\
\text { benzoic acid }\end{array}$ & $90 \mathrm{~g}$ & NL & NL & NL & No \\
\hline & $\begin{array}{l}2,4,5 \\
\text { trifluoro- } \\
\text { benzoic acid }\end{array}$ & $75 \mathrm{~g}$ & NL & NL & NL & No \\
\hline & $\begin{array}{l}2,6 \text { difluoro- } \\
\text { benzoic acid }\end{array}$ & $120 \mathrm{~g}$ & $\mathrm{NL}$ & $\mathrm{NL}$ & $\mathrm{NL}$ & No \\
\hline & $\begin{array}{l}\text { Cerium (III) } \\
\text { chloride } \\
\text { heptahydrate }\end{array}$ & $75 \mathrm{~g}$ & $\mathrm{NL}$ & $\mathrm{NL}$ & $\mathrm{NL}$ & No \\
\hline & $\begin{array}{l}\text { Lithium } \\
\text { bromide }\end{array}$ & $1.7 \mathrm{~kg}$ & $\mathrm{NL}$ & NL & NL & No \\
\hline & $\begin{array}{l}\text { Manganese } \\
\text { chloride } \\
\text { tetrahydrate }\end{array}$ & $2 \mathrm{~kg}$ & NL & NL & NL & No \\
\hline & $\begin{array}{l}\text { Nickel (III) } \\
\text { chloride } \\
\text { hexahydrate }\end{array}$ & $1 \mathrm{~kg}$ & NL & $\mathrm{NL}$ & NL & No \\
\hline & $\begin{array}{l}\text { Potassium } \\
\text { iodide }\end{array}$ & $1.05 \mathrm{~kg}$ & NL & $\mathrm{NL}$ & NL & No \\
\hline & Pyridone & $45 \mathrm{~g}$ & $\mathrm{NL}$ & $\mathrm{NL}$ & $\mathrm{NL}$ & No \\
\hline & $\begin{array}{l}\text { Samarium } \\
\text { Chloride } \\
\text { Hexahydrate }\end{array}$ & $75 \mathrm{~g}$ & $\mathrm{NL}$ & NL & NL & No \\
\hline & Sulfuric acid & $\begin{array}{l}100 \mathrm{ml} \\
(0.39 \mathrm{lb})^{\mathrm{G}}\end{array}$ & $\mathrm{NL}$ & $\begin{array}{l}1000 \\
(454 \mathrm{~kg})\end{array}$ & NL & No \\
\hline
\end{tabular}


Table A-3. Comparison of ESF Chemical Inventory to Threshold Quantity and Threshold Planning Quantity Limits (Continued)

\begin{tabular}{|c|c|c|c|c|c|c|}
\hline Location & Chemical & Inventory ${ }^{1}$ & $\begin{array}{c}29 \text { CFR } \\
1910.119 \\
\text { Threshold } \\
\text { Quantity } \\
\text { (b) }\end{array}$ & $\begin{array}{c}40 \text { CFR } 355 \\
\text { Threshold } \\
\text { Planning } \\
\text { Quantity } \\
\text { (lb) }\end{array}$ & $\begin{array}{c}\text { 40 CFR } \\
68.125 \\
\text { Threshold } \\
\text { Quantity } \\
\text { (lb) } \\
\end{array}$ & $\begin{array}{c}\text { Criteria } \\
\text { Exceeded? }\end{array}$ \\
\hline $\begin{array}{l}\text { ESF Pad/ } \\
\text { Busted Butte } \\
\text { Pad (cont'd) }\end{array}$ & $\begin{array}{l}\text { Pentafluoro- } \\
\text { benzoic acid }\end{array}$ & $100 \mathrm{~g}$ & NL & $\mathrm{NL}$ & $\mathrm{NL}$ & No \\
\hline $\begin{array}{l}\text { ESF South } \\
\text { Portal }\end{array}$ & Acetylene & $\begin{array}{l}500 \mathrm{ft}^{3} \\
(34.01 \mathrm{lb})^{\mathrm{H}}\end{array}$ & $\mathrm{NL}$ & $\mathrm{NL}$ & 10,000 & No \\
\hline $\begin{array}{l}\text { ESF Under- } \\
\text { ground }\end{array}$ & Acetylene & $\begin{array}{l}250 \mathrm{ft}^{3} \\
(17.01 \mathrm{lb})^{l}\end{array}$ & NL & $\mathrm{NL}$ & 10,000 & No \\
\hline $\begin{array}{l}\text { ESF (QC } \\
\text { Complex) }\end{array}$ & $\begin{array}{l}\text { Sodium } \\
\text { hydroxide }\end{array}$ & $3 \mathrm{lb}$ & $\mathrm{NL}$ & $\mathrm{NL}$ & $\mathrm{NL}$ & No \\
\hline \multirow[t]{2}{*}{$\begin{array}{l}\text { ESF } \\
\text { (Mechanics) }\end{array}$} & Acetylene & $\begin{array}{l}1500 \mathrm{ft}^{3} \\
(102.04 \mathrm{lb})^{\mathrm{J}}\end{array}$ & $\mathrm{NL}$ & NL & 10,000 & No \\
\hline & $\begin{array}{l}\text { Isopropyl } \\
\text { alcohol }\end{array}$ & $16 \mathrm{oz}$ & NL & $\mathrm{NL}$ & $\mathrm{NL}$ & No \\
\hline \multirow[t]{2}{*}{$\begin{array}{l}\text { ESF } \\
\text { (Painters) }\end{array}$} & Muriatic acid & $4 \mathrm{gal}$ & $\mathrm{NL}$ & $\mathrm{NL}$ & NL & No \\
\hline & $\begin{array}{l}\text { Isopropyl } \\
\text { alcohol }\end{array}$ & $1 \mathrm{gal}$ & NL & $\mathrm{NL}$ & NL & No \\
\hline $\begin{array}{l}\text { ESF (Pipe } \\
\text { Fitters) }\end{array}$ & Propane & $\begin{array}{l}99 \mathrm{oz} \\
(3.23 \mathrm{lb})^{\mathrm{K}}\end{array}$ & NL & $\mathrm{NL}$ & 10,000 & No \\
\hline \multirow[t]{2}{*}{$\begin{array}{l}\text { ESF (Tool } \\
\text { Crib) }\end{array}$} & Toluene & $\begin{array}{l}3 \mathrm{qt} \\
(5.42 \mathrm{lb})^{\mathrm{L}}\end{array}$ & NL & $\mathrm{NL}$ & $\mathrm{NL}$ & No \\
\hline & Propane & $\begin{array}{l}2048 \mathrm{oz} \\
(66.76 \mathrm{lb})^{\mathrm{M}}\end{array}$ & NL & $\mathrm{NL}$ & 10,000 & No \\
\hline \multirow[t]{2}{*}{$\begin{array}{l}\text { ESF } \\
\text { Warehouse }\end{array}$} & Muriatic acid & $11 \mathrm{gal}$ & $\mathrm{NL}$ & $\mathrm{NL}$ & $\mathrm{NL}$ & No \\
\hline & $\begin{array}{l}\text { Calcium } \\
\text { Hypochlorite }\end{array}$ & $100 \mathrm{lb}$ & $\mathrm{NL}$ & $\mathrm{NL}$ & NL & No \\
\hline $\begin{array}{l}\text { FSC at } \\
\text { Reclamation } \\
\text { Storage } \\
\text { Area }\end{array}$ & Butane & $\begin{array}{l}30 \mathrm{oz} \\
(1.17 \mathrm{lb})^{\mathrm{N}}\end{array}$ & NL & $\mathrm{NL}$ & 10,000 & No \\
\hline $\begin{array}{l}\text { HRF Bldg } \\
4125\end{array}$ & $\begin{array}{l}\text { 7-amino-1-3- } \\
\text { Naphthalene } \\
\text { disulfonic } \\
\text { acid }\end{array}$ & $1 \mathrm{~kg}$ & $\mathrm{NL}$ & $\mathrm{NL}$ & $\mathrm{NL}$ & No \\
\hline \multirow[t]{4}{*}{$\begin{array}{l}\text { Hydrochem/ } \\
\text { Geophysical } \\
\text { Labs Bldg } \\
4215\end{array}$} & Acetonitrile & $\begin{array}{l}21 \\
(3.46 \mathrm{lb})^{\circ}\end{array}$ & NL & $\mathrm{NL}$ & $\mathrm{NL}$ & No \\
\hline & $\begin{array}{l}\text { Barium } \\
\text { chloride } \\
\text { dihydrate }\end{array}$ & $1000 \mathrm{~g}$ & NL & $\mathrm{NL}$ & $\mathrm{NL}$ & No \\
\hline & $\begin{array}{l}\text { Mercuric } \\
\text { chloride }\end{array}$ & $100 \mathrm{~g}$ & $\mathrm{NL}$ & 500 & $\mathrm{NL}$ & No \\
\hline & Methanol & 41 & $\mathrm{NL}$ & $\mathrm{NL}$ & $\mathrm{NL}$ & No \\
\hline
\end{tabular}


Table A-3. Comparison of ESF Chemical Inventory to Threshold Quantity and Threshold Planning Quantity Limits (Continued)

\begin{tabular}{|c|c|c|c|c|c|c|}
\hline Location & Chemical & Inventory ${ }^{1}$ & $\begin{array}{c}29 \text { CFR } \\
1910.119 \\
\text { Threshold } \\
\text { Quantity } \\
\text { (lb) }\end{array}$ & $\begin{array}{c}40 \text { CFR } 355 \\
\text { Threshold } \\
\text { Planning } \\
\text { Quantity } \\
\text { (lb) }\end{array}$ & $\begin{array}{l}\text { 40 CFR } \\
68.125 \\
\text { Threshold } \\
\text { Quantity } \\
\text { (lb) }\end{array}$ & $\begin{array}{c}\text { Criteria } \\
\text { Exceeded? }\end{array}$ \\
\hline \multirow[t]{16}{*}{$\begin{array}{l}\text { Hydrochem/ } \\
\text { Geophysical } \\
\text { Labs Bldg } \\
4215 \\
\text { (cont'd) }\end{array}$} & Nitric acid & $\begin{array}{l}1 \mathrm{ml} \\
(3.31 \mathrm{E}- \\
03 \mathrm{lb})^{\mathrm{P}}\end{array}$ & $\begin{array}{l}500 \\
(\geq 94.5 \%)\end{array}$ & 1000 & 15,000 & No \\
\hline & $\begin{array}{l}\text { Barium } \\
\text { chloride, } \\
\text { anhydrous }\end{array}$ & $500 \mathrm{~g}$ & $\mathrm{NL}$ & $\mathrm{NL}$ & $\mathrm{NL}$ & No \\
\hline & $\begin{array}{l}4-(2- \\
\text { pyridylazo) } \\
\text { resorcinol }\end{array}$ & $\begin{array}{l}5 \mathrm{~g} \\
(0.01 \mathrm{lb})\end{array}$ & $\mathrm{NL}$ & NL & NL & No \\
\hline & $\begin{array}{l}\text { 4-methyl-2- } \\
\text { pentanone }\end{array}$ & 11 & NL & $\mathrm{NL}$ & $\mathrm{NL}$ & No \\
\hline & $\begin{array}{l}\text { Acetic acid, } \\
\text { sodium salt } \\
\text { trihydrate }\end{array}$ & $500 \mathrm{~g}$ & $\mathrm{NL}$ & $\mathrm{NL}$ & $\mathrm{NL}$ & No \\
\hline & $\begin{array}{l}\text { Ammonium } \\
\text { hydroxide } \\
(30 \%)\end{array}$ & $\begin{array}{l}41 \\
(8.25 \mathrm{lb})^{\mathrm{Q}}\end{array}$ & $\mathrm{NL}$ & NL & NL & No \\
\hline & $\begin{array}{l}\text { Hydroxyl } \\
\text { amnine } \\
\text { hydro- } \\
\text { chloride }\end{array}$ & $100 \mathrm{~g}$ & $\mathrm{NL}$ & $\mathrm{NL}$ & $\mathrm{NL}$ & No \\
\hline & $\begin{array}{l}\text { Lanthanum } \\
\text { chloride }\end{array}$ & $250 \mathrm{~g}$ & $\mathrm{NL}$ & $\mathrm{NL}$ & $\mathrm{NL}$ & No \\
\hline & $\begin{array}{l}\text { Lanthanum } \\
\text { chloride, } 7- \\
\text { hydrate }\end{array}$ & $75 \mathrm{~g}$ & NL & NL & NL & No \\
\hline & $\begin{array}{l}\text { Magnesium } \\
\text { (1000 ppm) }\end{array}$ & $500 \mathrm{ml}$ & $\mathrm{NL}$ & $\mathrm{NL}$ & $\mathrm{NL}$ & No \\
\hline & $\begin{array}{l}\text { Oxalic acid, } \\
\text { anhydrous }\end{array}$ & $50 \mathrm{~g}$ & NL & NL & NL & No \\
\hline & $\begin{array}{l}\text { Sodium } \\
\text { hydroxide } \\
10 \mathrm{~N} \text { soln. }\end{array}$ & $\begin{array}{l}5 \mathrm{I} \\
(4.41 \mathrm{lb})^{\mathrm{R}}\end{array}$ & $\mathrm{NL}$ & NL & NL & No \\
\hline & $\begin{array}{l}\text { Sodium } \\
\text { sulfite, } \\
\text { anhydrous }\end{array}$ & $500 \mathrm{~g}$ & $\mathrm{NL}$ & NL & NL & No \\
\hline & $\begin{array}{l}\text { Strontium } \\
\text { chloride, } 6 \\
\text { hydrate } \\
\text { crystal }\end{array}$ & $500 \mathrm{~g}$ & $\mathrm{NL}$ & NL & $\mathrm{NL}$ & No \\
\hline & $\begin{array}{l}\text { Strontium } \\
1000 \mathrm{ppm}\end{array}$ & $500 \mathrm{ml}$ & $\mathrm{NL}$ & NL & NL & No \\
\hline & $\begin{array}{l}\text { Sodium } \\
\text { hydroxide }\end{array}$ & $\begin{array}{l}125 \mathrm{~g} \\
(0.28 \mathrm{lb})\end{array}$ & NL & NL & NL & No \\
\hline
\end{tabular}


Table A-3. Comparison of ESF Chemical Inventory to Threshold Quantity and Threshold Planning Quantity Limits (Continued)

\begin{tabular}{|c|c|c|c|c|c|c|}
\hline Location & Chemical & Inventory ${ }^{1}$ & $\begin{array}{c}29 \text { CFR } \\
1910.119 \\
\text { Threshold } \\
\text { Quantity } \\
\text { (lb) }\end{array}$ & $\begin{array}{l}40 \text { CFR } 355 \\
\text { Threshold } \\
\text { Planning } \\
\text { Quantity } \\
\text { (lb) }\end{array}$ & $\begin{array}{l}40 \text { CFR } \\
68.125 \\
\text { Threshold } \\
\text { Quantity } \\
\text { (Ib) }\end{array}$ & $\begin{array}{c}\text { Criteria } \\
\text { Exceeded? }\end{array}$ \\
\hline \multirow[t]{5}{*}{$\begin{array}{l}\text { Hydrochem/ } \\
\text { Geophysical } \\
\text { Labs Bldg } \\
4215 \\
\text { (cont'd) }\end{array}$} & $\begin{array}{l}1,10 \\
\text { phenanthro- } \\
\text { line, mono- } \\
\text { hydrate }\end{array}$ & $5 \mathrm{~g}$ & $\mathrm{NL}$ & $\mathrm{NL}$ & $\mathrm{NL}$ & No \\
\hline & $\begin{array}{l}2,3 \text { diamino } \\
\text { prionic acid } \\
\text { monohydro } \\
\text { chloride }\end{array}$ & $5 \mathrm{~g}$ & $\mathrm{NL}$ & $\mathrm{NL}$ & $\mathrm{NL}$ & No \\
\hline & $\begin{array}{l}\text { Sulfuric acid } \\
(85 \%)\end{array}$ & $\begin{array}{l}71 \\
(27.34 \mathrm{lb})^{s} \\
\end{array}$ & $\mathrm{NL}$ & $\begin{array}{l}1000 \\
(454 \mathrm{~kg})\end{array}$ & $\mathrm{NL}$ & No \\
\hline & Acetonitrile & $\begin{array}{l}21 \\
(3.46 \mathrm{lb})^{\top}\end{array}$ & $\mathrm{NL}$ & $\mathrm{NL}$ & $\mathrm{NL}$ & No \\
\hline & 8-Quinolinol & $5 \mathrm{~g}$ & $\mathrm{NL}$ & $\mathrm{NL}$ & $\mathrm{NL}$ & No \\
\hline \multirow[t]{16}{*}{$\begin{array}{l}\text { Hydrology } \\
\text { Lab Bldg } \\
4215\end{array}$} & $\begin{array}{l}\text { Aluminum } \\
\text { oxide }\end{array}$ & $2.5 \mathrm{~kg}$ & $\mathrm{NL}$ & $\mathrm{NL}$ & $\mathrm{NL}$ & No \\
\hline & Methanol & 11 & $\mathrm{NL}$ & $\mathrm{NL}$ & $\mathrm{NL}$ & No \\
\hline & $\begin{array}{l}\text { Aluminum } \\
\text { Oxide }\end{array}$ & $1 \mathrm{lb}$ & NL & $\mathrm{NL}$ & NL & No \\
\hline & Mercury & $75 \mathrm{lb}$ & $\mathrm{NL}$ & $\mathrm{NL}$ & NNL & No \\
\hline & $\begin{array}{l}\text { Potassium } \\
\text { Bicarbonate }\end{array}$ & $500 \mathrm{~g}$ & $\mathrm{NL}$ & $\mathrm{NL}$ & NL & No \\
\hline & Acetone & $\begin{array}{l}41 \\
(6.96 \mathrm{lb})^{\mathrm{U}}\end{array}$ & $\mathrm{NL}$ & $\mathrm{NL}$ & $\mathrm{NL}$ & No \\
\hline & $\begin{array}{l}\text { Aluminum } \\
\text { Nitrate 9- } \\
\text { hydrate }\end{array}$ & $10 \mathrm{lb}$ & $\mathrm{NL}$ & $\mathrm{NL}$ & NL & No \\
\hline & $\begin{array}{l}\text { Calcium } \\
\text { Selenate } \\
(99 \%)\end{array}$ & $438 \mathrm{~g}$ & $\mathrm{NL}$ & NL & $\mathrm{NL}$ & No \\
\hline & $\begin{array}{l}\text { Calcium } \\
\text { Sulfate }\end{array}$ & $500 \mathrm{~g}$ & $\mathrm{NL}$ & NL & $\mathrm{NL}$ & No \\
\hline & Helium & 1 cylinder & $\mathrm{NL}$ & $\mathrm{NL}$ & $\mathrm{NL}$ & No \\
\hline & $\begin{array}{l}\text { Isopropyl } \\
\text { alcohol }\end{array}$ & $1 \mathrm{gal}$ & NL & NL & $\mathrm{NL}$ & No \\
\hline & $\begin{array}{l}\text { Potassium } \\
\text { iodine }\end{array}$ & $2 \mathrm{lb}$ & NL & $\mathrm{NL}$ & $\mathrm{NL}$ & No \\
\hline & $\begin{array}{l}\text { Potassium } \\
\text { nitrate }\end{array}$ & $500 \mathrm{~g}$ & $\mathrm{NL}$ & $\mathrm{NL}$ & NL & No \\
\hline & $\begin{array}{l}\text { Potassium } \\
\text { sulfate }\end{array}$ & $500 \mathrm{~g}$ & NL & $\mathrm{NL}$ & NL & No \\
\hline & $\begin{array}{l}\text { Sodium } \\
\text { carbonate, } \\
\text { anhydrous }\end{array}$ & $1 \mathrm{lb}$ & $\mathrm{NL}$ & $\mathrm{NL}$ & NL & No \\
\hline & $\begin{array}{l}\text { Sodium } \\
\text { pyro- } \\
\text { phosphate }\end{array}$ & $2.5 \mathrm{~kg}$ & $\mathrm{NL}$ & $\mathrm{NL}$ & $\mathrm{NL}$ & No \\
\hline
\end{tabular}


Table A-3. Comparison of ESF Chemical Inventory to Threshold Quantity and Threshold Planning Quantity Limits (Continued)

\begin{tabular}{|c|c|c|c|c|c|c|}
\hline Location & Chemical & Inventory ${ }^{1}$ & $\begin{array}{c}29 \text { CFR } \\
1910.119 \\
\text { Threshold } \\
\text { Quantity } \\
\text { (Ib) }\end{array}$ & $\begin{array}{c}40 \text { CFR } 355 \\
\text { Threshold } \\
\text { Planning } \\
\text { Quantity } \\
\text { (lb) }\end{array}$ & $\begin{array}{c}40 \text { CFR } \\
68.125 \\
\text { Threshold } \\
\text { Quantity } \\
\text { (lb) }\end{array}$ & $\begin{array}{c}\text { Criteria } \\
\text { Exceeded? }\end{array}$ \\
\hline \multirow[t]{6}{*}{$\begin{array}{l}\text { Hydrology } \\
\text { Lab Bldg } \\
4215 \\
\text { (cont'd) }\end{array}$} & $\begin{array}{l}\text { Cupric } \\
\text { sulfate }\end{array}$ & $\begin{array}{l}2.27 \mathrm{~kg} \\
(5.00 \mathrm{lb})\end{array}$ & NL & $\mathrm{NL}$ & $\mathrm{NL}$ & No \\
\hline & $\begin{array}{l}\text { Lithium } \\
\text { chloride }\end{array}$ & $1500 \mathrm{~g}$ & $\mathrm{NL}$ & $\mathrm{NL}$ & $\mathrm{NL}$ & No \\
\hline & $\begin{array}{l}\text { Potassium } \\
\text { chloride }\end{array}$ & $1000 \mathrm{~g}$ & $\mathrm{NL}$ & $\mathrm{NL}$ & $\mathrm{NL}$ & No \\
\hline & $\begin{array}{l}\text { Sodium } \\
\text { hydroxide } \\
(50 \%)\end{array}$ & $\begin{array}{l}1 \mathrm{pt} \\
(1.59 \mathrm{lb})^{\mathrm{v}}\end{array}$ & $\mathrm{NL}$ & NL & $\mathrm{NL}$ & No \\
\hline & $\begin{array}{l}\text { Sodium } \\
\text { chloride }\end{array}$ & $1500 \mathrm{~g}$ & $\mathrm{NL}$ & $\mathrm{NL}$ & $\mathrm{NL}$ & No \\
\hline & $\begin{array}{l}\text { Magnesium } \\
\text { sulfate }\end{array}$ & $500 \mathrm{~g}$ & $\mathrm{NL}$ & $\mathrm{NL}$ & $\mathrm{NL}$ & No \\
\hline $\begin{array}{l}\text { Mine } \\
\text { Rescue }\end{array}$ & Methane & $\begin{array}{l}4 \mathrm{ft}^{3} \\
(0.18 \mathrm{lb})^{w}\end{array}$ & $\mathrm{NL}$ & NL & 10,000 & \\
\hline $\begin{array}{l}\text { Reclamation } \\
\text { Storage } \\
\text { Area }\end{array}$ & Nitrogen & $510 \mathrm{ft}^{3}$ & NL & NL & NL & No \\
\hline $\begin{array}{l}\text { Reclamation } \\
\text { Storage } \\
\text { Area Boxcar }\end{array}$ & $\begin{array}{l}\text { Sodium } \\
\text { hydroxide }\end{array}$ & $1000 \mathrm{lb}$ & NL & NL & NL & No \\
\hline $\begin{array}{l}\text { Site 1, NTS- } \\
60 \text { (tower) }\end{array}$ & $\begin{array}{l}\text { Isopropyl } \\
\text { alcohol }\end{array}$ & $64 \mathrm{oz}$ & $\mathrm{NL}$ & NL & $\mathrm{NL}$ & No \\
\hline \multirow[t]{6}{*}{$\begin{array}{l}\text { Site } \\
\text { Maintenance } \\
\text { Bldg } 4222\end{array}$} & Acetylene & $\begin{array}{l}1 \text { cylinder } \\
\left(250 \mathrm{ft}^{3}\right) \\
(17.01 \mathrm{lb})^{\mathrm{x}}\end{array}$ & NL & NL & 10,000 & No \\
\hline & $\begin{array}{l}\text { Hydro- } \\
\text { chloric acid }\end{array}$ & $\begin{array}{l}1.1 \mathrm{pt} \\
(1.37 \mathrm{Jb})^{\gamma}\end{array}$ & 5000 & NL & NL & No \\
\hline & Propane & $\begin{array}{l}5 \text { tanks } \\
(55-\mathrm{lb} \\
\text { tanks) }\end{array}$ & NL & $\mathrm{NL}$ & 10,000 & No \\
\hline & $\begin{array}{l}\text { Sulfur hexa- } \\
\text { fluoride }\end{array}$ & 10 tanks & NL & $\mathrm{NL}$ & $\mathrm{NL}$ & No \\
\hline & $\begin{array}{l}\text { Carbon } \\
\text { dioxide }\end{array}$ & 1 tank & NL & $\mathrm{NL}$ & NL & No \\
\hline & Argon & 1 bottle & $\mathrm{NL}$ & $\mathrm{NL}$ & $\mathrm{NL}$ & No \\
\hline \multirow[t]{3}{*}{$\begin{array}{l}\text { Soils Lab } \\
\text { Bldg } 4222 \\
\end{array}$} & Acetone & $\begin{array}{l}27.36 \mathrm{I} \\
(47.60 \mathrm{lb})^{\mathrm{z}}\end{array}$ & $\mathrm{NL}$ & NL & NL & No \\
\hline & $\begin{array}{l}\text { Hydro- } \\
\text { chloric acid } \\
1 \mathrm{~N} \text { soln. }\end{array}$ & $\begin{array}{l}1.5 \mathrm{I} \\
(0.12 \mathrm{lb})^{\mathrm{AA}}\end{array}$ & 5000 & $\mathrm{NL}$ & 15,000 & No \\
\hline & $\begin{array}{l}\text { Hydro- } \\
\text { chloric acid } \\
\text { trace metals }\end{array}$ & 101 & $\mathrm{NL}$ & $\mathrm{NL}$ & $\mathrm{NL}$ & No \\
\hline
\end{tabular}


Table A-3. Comparison of ESF Chemical Inventory to Threshold Quantity and Threshold Planning Quantity Limits (Continued)

\begin{tabular}{|c|c|c|c|c|c|c|}
\hline Location & Chemical & Inventory & $\begin{array}{c}\text { 29 CFR } \\
\text { 1910.119 } \\
\text { Threshold } \\
\text { Quantity } \\
\text { (lb) }\end{array}$ & $\begin{array}{l}40 \text { CFR } 355 \\
\text { Threshold } \\
\text { Planning } \\
\text { Quantity } \\
\text { (Ib) }\end{array}$ & $\begin{array}{c}40 \text { CFR } \\
68.125 \\
\text { Threshold } \\
\text { Quantity } \\
\text { (lb) }\end{array}$ & $\begin{array}{c}\text { Criteria } \\
\text { Exceeded? }\end{array}$ \\
\hline \multirow[t]{2}{*}{$\begin{array}{l}\text { Soils Lab } \\
\text { Bldg } 4222 \\
\text { (cont'd) }\end{array}$} & $\begin{array}{l}\text { Sodium } \\
\text { hydroxide } \\
(50 \%)\end{array}$ & $\begin{array}{l}500 \mathrm{ml} \\
(1.68 \mathrm{lb})^{\mathrm{BB}}\end{array}$ & $\mathrm{NL}$ & $\mathrm{NL}$ & $\mathrm{NL}$ & No \\
\hline & $\begin{array}{l}\text { Sodium } \\
\text { hydroxide } \\
\text { iN soln. }\end{array}$ & $\begin{array}{l}1 \mathrm{I} \\
(0.09 \mathrm{lb})^{\mathrm{CC}}\end{array}$ & $\mathrm{NL}$ & $\mathrm{NL}$ & $\mathrm{NL}$ & No \\
\hline \multirow[t]{2}{*}{$\begin{array}{l}\text { Tracer } \\
\text { Trailer }\end{array}$} & Argon & 2 tanks & $\mathrm{NL}$ & $\mathrm{NL}$ & $\mathrm{NL}$ & No \\
\hline & Helium & 1 tank & $\mathrm{NL}$ & $\mathrm{NL}$ & $\mathrm{NL}$ & No \\
\hline \multirow[t]{4}{*}{$\begin{array}{l}\text { Waste } \\
\text { Manage- } \\
\text { ment Area }\end{array}$} & $\begin{array}{l}\text { Carbon } \\
\text { tetrachloride }\end{array}$ & $\begin{array}{l}580 \mathrm{ml} \\
(2.04 \mathrm{lb})^{\mathrm{DD}}\end{array}$ & $\mathrm{NL}$ & $\mathrm{NL}$ & $N L$ & No \\
\hline & $\begin{array}{l}\text { Aluminum } \\
\text { chloride } \\
\text { anhydrous }\end{array}$ & $44 \mathrm{~g}$ & $\mathrm{NL}$ & $\mathrm{NL}$ & $\mathrm{NL}$ & No \\
\hline & Toluene & $\begin{array}{l}1 \mathrm{qt} \\
(1.81 \mathrm{lb})^{\mathrm{EE}}\end{array}$ & $\mathrm{NL}$ & NL & $\mathrm{NL}$ & No \\
\hline & Propane & $\begin{array}{l}42.2 \mathrm{oz} \\
(1.38 \mathrm{Ib})^{\mathrm{FF}}\end{array}$ & $\mathrm{NL}$ & NL & 10,000 & No \\
\hline
\end{tabular}

NL - Not Listed; no TQ or TPQ was listed in the respective CFR

${ }^{1}$ Inventory obtained from the M\&O Material Inventory Database 
Inventory determination notes:

A. Nitric Acid density $=1.5040 \mathrm{~kg} / \mathrm{l}$ at $25^{\circ} \mathrm{C}$ for 100 percent concentration (Perry 1973, Table 368 , p. 3-76)

$$
100 \mathrm{ml} \times \frac{\mathrm{l}}{1000 \mathrm{ml}} \times \frac{1.504 \mathrm{~kg}}{l} \frac{\mathrm{lb}}{0.454 \mathrm{~kg}}=0.33 \mathrm{lb}
$$

B. Acetone (2-Propanone) density $=0.7899 \mathrm{~kg} / \mathrm{l}$ at $20^{\circ} \mathrm{C}$ for 100 percent concentration (Weast 1972 , p. C-455)

$$
3 \mathrm{gal} \times \frac{3.7854 \mathrm{l}}{\mathrm{gal}} \times \frac{0.7899 \mathrm{~kg}}{\mathrm{l}} \frac{\mathrm{lb}}{0.454 \mathrm{~kg}}=19.76 \mathrm{lb}
$$

C. Hydrochloric Acid density $=1.1980 \mathrm{~kg} / \mathrm{l}$ at $20^{\circ} \mathrm{C}$ for 40 percent concentration (Perry 1973, Table 3-59, p. 3-75)

$$
7 \mathrm{gal} \times \frac{3.7854 \mathrm{l}}{\mathrm{gal}} \times \frac{1.1980 \mathrm{~kg}}{l} \frac{\mathrm{lb}}{0.454 \mathrm{~kg}}=69.92 \mathrm{lb}
$$

D. Acetonitrile (acetic acid, nitrile) density $=0.7857 \mathrm{~kg} / \mathrm{l}$ at $20^{\circ} \mathrm{C}$ for 100 percent concentration (Weast 1972, p. C-81)

$$
4 l \times \frac{0.7857 \mathrm{~kg}}{l} \times \frac{\mathrm{lb}}{0.454 \mathrm{~kg}}=6.92 \mathrm{lb}
$$

E. Phosphoric Acid density $=1.870 \mathrm{~kg} / \mathrm{l}$ at $20^{\circ} \mathrm{C}$ for 100 percent concentration (Perry 1973, Table 3-70)

$$
500 \mathrm{ml} \times \frac{\mathrm{l}}{1000 \mathrm{ml}} \times \frac{1.870 \mathrm{~kg}}{l} \times \frac{\mathrm{lb}}{0.454 \mathrm{~kg}}=2.06 \mathrm{lb}
$$

F. Acetylene density $=14.7 \mathrm{ft}^{3} / \mathrm{lb}$ at $20^{\circ} \mathrm{C}$ for 100 percent concentration (see assumption 3.3 .1 )

$$
250 f t^{3} \times \frac{l b}{14.7 f t^{3}}=17.01 l b
$$


G. Sulfuric Acid density $=1.7732 \mathrm{~kg} / \mathrm{l}$ at $25^{\circ} \mathrm{C}$ for 100 percent concentration (Perry 1973 , Table 3-103)

$$
100 \mathrm{ml} \times \frac{\mathrm{l}}{1000 \mathrm{ml}} \times \frac{1.7732 \mathrm{~kg}}{l} \times \frac{\mathrm{lb}}{0.454 \mathrm{~kg}}=0.39 \mathrm{lb}
$$

H. Acetylene density $=14.7 \mathrm{ft}^{3} / \mathrm{lb}$ at $20^{\circ} \mathrm{C}$ for 100 percent concentration (see assumption 3.3 .1 )

$$
2 \times 250 f t^{3} \times \frac{l b}{14.7 f t^{3}}=34.01 \mathrm{lb}
$$

I. Acetylene density $=14.7 \mathrm{ft}^{3} / 1 \mathrm{~b}$ at $20^{\circ} \mathrm{C}$ for 100 percent concentration (see assumption 3.3 .1 )

$$
250 f t^{3} \times \frac{l b}{14.7 f t^{3}}=17.01 \mathrm{lb}
$$

J. Acetylene density $=14.7 \mathrm{ft}^{3} / \mathrm{lb}$ at $20^{\circ} \mathrm{C}$ for 100 percent concentration (see assumption 3.3 .1 )

$$
1500 f t^{3} \times \frac{l b}{14.7 f t^{3}}=102.04 l b
$$

K. Propane density $=0.5005 \mathrm{~kg} / \mathrm{l}$ at $20^{\circ} \mathrm{C}$ for 100 percent concentration (Weast $1972, \mathrm{p} . \mathrm{C}-440$ )

$$
99 o z \times \frac{2.957 E-02 l}{o z} \times \frac{0.5005 \mathrm{~kg}}{l} \times \frac{\mathrm{lb}}{0.454 \mathrm{~kg}}=3.23 \mathrm{lb}
$$

L. Toluene density $=0.8669 \mathrm{~kg} / \mathrm{l}$ at $25^{\circ} \mathrm{C}$ for 100 percent concentration (Weast $1972, \mathrm{p} . \mathrm{C}-512$ )

$$
3 q t \times \frac{g a l}{4 q t} \times \frac{3.785 l}{g a l} \times \frac{0.8669 \mathrm{~kg}}{l} \times \frac{\mathrm{lb}}{0.454 \mathrm{~kg}}=5.42 \mathrm{lb}
$$

M. Propane density $=0.5005 \mathrm{~kg} / 1$ at $20^{\circ} \mathrm{C}$ for 100 percent concentration (Weast 1972 , p. C-440)

$$
2048 \mathrm{oz} \times \frac{2.957 E-02 \mathrm{l}}{o z} \times \frac{0.5005 \mathrm{~kg}}{l} \times \frac{\mathrm{lb}}{0.454 \mathrm{~kg}}=66.76 \mathrm{lb}
$$


N. Butane density $=0.6012 \mathrm{~kg} / \mathrm{l}$ at $0^{\circ} \mathrm{C}$ for 100 percent concentration (Weast $1972, \mathrm{p} . \mathrm{C}-211$ )

$$
30 o z \times \frac{2.957 E-02 l}{o z} \times \frac{0.6012 \mathrm{~kg}}{l} \times \frac{\mathrm{lb}}{0.454 \mathrm{~kg}}=1.17 \mathrm{lb}
$$

O. Acetonitrile (acetic acid, nitrile) density $=0.7857 \mathrm{~kg} / \mathrm{l}$ at $20^{\circ} \mathrm{C}$ for 100 percent concentration (Weast 1972, p. C-81)

$$
2 l \times \frac{0.7857 \mathrm{~kg}}{l} \times \frac{\mathrm{lb}}{0.454 \mathrm{~kg}}=3.46 \mathrm{lb}
$$

P. Nitric Acid density $=1.5040 \mathrm{~kg} / \mathrm{l}$ at $25^{\circ} \mathrm{C}$ for 100 percent concentration (Perry 1973, Table 368, p. 3-76)

$$
1 \mathrm{ml} \times \frac{\mathrm{l}}{1000 \mathrm{ml}} \times \frac{1.504 \mathrm{~kg}}{l} \times \frac{\mathrm{lb}}{0.454 \mathrm{~kg}}=3.31 E-03 \mathrm{lb}
$$

Q. Ammonium Hydroxide density $=0.9361 \mathrm{~kg} / 1$ at $25^{\circ} \mathrm{C}$ for 30 percent concentration (Weast 1972, p. D-183)

$$
4 l \times \frac{0.9361 \mathrm{~kg}}{l} \times \frac{\mathrm{lb}}{0.454 \mathrm{~kg}}=8.25 \mathrm{lb}
$$

R. Sodium Hydroxide, $10 \mathrm{~N}$ solution (i.e., by definition of Normality, there are $10 \mathrm{~g}$ solute per liter of solution). The molecular weight of $\mathrm{NaOH}$ is $40 \mathrm{~g} / \mathrm{mol}$. To find the quantity of $\mathrm{NaOH}$ in 51 of $10 \mathrm{~N}$ solution:

$$
10 N=\frac{x g}{40 \mathrm{~g} / \mathrm{mol}} \mathrm{mol} /
$$

Or

$$
\begin{gathered}
\mathrm{x}=2000 \mathrm{~g} \\
2000 \mathrm{~g} \times \frac{\mathrm{kg}}{1000 \mathrm{~g}} \times \frac{\mathrm{lb}}{0.454 \mathrm{~kg}}=4.41 \mathrm{lb}
\end{gathered}
$$


S. Sulfuric Acid density $=1.7732 \mathrm{~kg} / \mathrm{l}$ at $25^{\circ} \mathrm{C}$ for 100 percent concentration (Perry 1973, Table 3-103)

$$
7 l \times \frac{1.7732 \mathrm{~kg}}{l} \times \frac{\mathrm{lb}}{0.454 \mathrm{~kg}}=27.34 \mathrm{lb}
$$

T. Acetonitrile (acetic acid, nitrile) density $=0.7857 \mathrm{~kg} / 1$ at $20{ }^{\circ} \mathrm{C}$ for 100 percent concentration (Weast 1972, p. C-81)

$$
2 l \times \frac{0.7857 \mathrm{~kg}}{l} \times \frac{\mathrm{lb}}{0.454 \mathrm{~kg}}=3.46 \mathrm{lb}
$$

U. Acetone (2-Propanone) density $=0.7899 \mathrm{~kg} / \mathrm{l}$ at $20{ }^{\circ} \mathrm{C}$ for 100 percent concentration (Weast 1972, p. C-455)

$$
4 l \times \frac{0.7899 \mathrm{~kg}}{l} \times \frac{\mathrm{lb}}{0.454 \mathrm{~kg}}=6.96 \mathrm{lb}
$$

V. Sodium Hydroxide density $=1.5253 \mathrm{~kg} / 1$ at $20{ }^{\circ} \mathrm{C}$ for 50 percent concentration (Perry 1973 , Table 3-92, p. 3-78)

$$
1 p t \times \frac{q t}{2 p t} \times \frac{g a l}{4 q t} \times \frac{3.785 l}{g a l} \times \frac{1.5253 \mathrm{~kg}}{l} \times \frac{\mathrm{lb}}{0.454 \mathrm{~kg}}=1.59 \mathrm{lb}
$$

W. Methane density $=.0448 \mathrm{lb} / \mathrm{ft}^{3}$ at $20^{\circ} \mathrm{C}$ (Perry 1973, Table $3-31$, p. 3-72)

$$
4 f t^{3} \times \frac{0.0448 \mathrm{lb}}{f t^{3}}=0.18 \mathrm{lb}
$$

$\mathrm{X}$ Acetylene density $=14.7 \mathrm{ft}^{3} / \mathrm{lb}$ at $20^{\circ} \mathrm{C}$ for 100 percent concentration (see assumption 3.3 .1 )

$$
250 f t^{3} \times \frac{l b}{14.7 f t^{3}}=17.011 b
$$


Y. Hydrochloric Acid density $=1.1980 \mathrm{~kg} / \mathrm{l}$ at $20^{\circ} \mathrm{C}$ for 40 percent concentration (Perry 1973 , Table 3-59, p. 3-75)

$$
1.1 p t \times \frac{q t}{2 p t} \times \frac{g a l}{4 q t} \times \frac{3.785 \mathrm{l}}{g a l} \times \frac{1.1980 \mathrm{~kg}}{l} \times \frac{\mathrm{lb}}{0.454 \mathrm{~kg}}=1.37 \mathrm{lb}
$$

Z. Acetone (2-Propanone) density $=0.7899 \mathrm{~kg} / \mathrm{l}$ at $20^{\circ} \mathrm{C}$ for 100 percent concentration (Weast 1972 , p. C-455)

$$
27.36 l \times \frac{0.7899 \mathrm{~kg}}{l} \times \frac{\mathrm{lb}}{0.454 \mathrm{~kg}}=47.60 \mathrm{lb}
$$

AA. Hydrochloric Acid, $1 \mathrm{~N}$ solution (i.e., by definition of Normality, there is 1-g solute per liter of solution). The molecular weight of $\mathrm{HCl}$ is $36.47 \mathrm{~g} / \mathrm{mol}$. To find the quantity of $\mathrm{HCl}$ in 1.51 of $1 \mathrm{~N}$ solution:

$$
1 N=\frac{x g}{36.47 \mathrm{~g} / \mathrm{mol}} \mathrm{mol} /
$$

Solving

$$
\mathrm{x}=54.71 \mathrm{~g}
$$

$$
54.71 \mathrm{~g} \times \frac{\mathrm{kg}}{1000 \mathrm{~g}} \times \frac{\mathrm{lb}}{0.454 \mathrm{~kg}}=0.12 \mathrm{lb}
$$

BB. Sodium Hydroxide density $=1.5253 \mathrm{~kg} / 1$ at $20^{\circ} \mathrm{C}$ for 50 percent concentration (Perry 1973 , Table 3-92, p. 3-78)

$$
500 \mathrm{ml} \times \frac{\mathrm{l}}{1000 \mathrm{ml}} \times \frac{1.5253 \mathrm{~kg}}{l} \times \frac{\mathrm{lb}}{0.454 \mathrm{~kg}}=1.68 \mathrm{lb}
$$


CC. Sodium Hydroxide, $1 \mathrm{~N}$ solution (i.e., by definition of Normality, there is 1-g solute per liter of solution). The molecular weight of $\mathrm{NaOH}$ is $40.0 \mathrm{~g} / \mathrm{mol}$. To find the quantity of $\mathrm{NaOH}$ in 11 of $1 \mathrm{~N}$ solution:

$$
1 N=\frac{x g}{40.0 \mathrm{~g} / \mathrm{mol}} \mathrm{mol} /
$$

Solving

$$
\begin{gathered}
\mathrm{x}=40.00 \mathrm{~g} \\
40.0 \mathrm{~g} \times \frac{\mathrm{kg}}{1000 \mathrm{~g}} \times \frac{\mathrm{lb}}{0.454 \mathrm{~kg}}=0.09 \mathrm{lb}
\end{gathered}
$$

DD. Carbon Tetrachloride density $=1.595 \mathrm{~kg} / \mathrm{l}$ at $20{ }^{\circ} \mathrm{C}$ for 100 percent concentration (Perry 1973, Table 3-2, p. 3-28)

$$
580 \mathrm{ml} \times \frac{\mathrm{l}}{1000 \mathrm{ml}} \times \frac{1.595 \mathrm{~kg}}{l} \times \frac{\mathrm{lb}}{0.454 \mathrm{~kg}}=2.04 \mathrm{lb}
$$

EE. Toluene density $=0.8669 \mathrm{~kg} / 1$ at $25^{\circ} \mathrm{C}$ for 100 percent concentration (Weast 1972 , p. C512)

$$
1 q t \times \frac{g a l}{4 q t} \times \frac{3.785 l}{g a l} \times \frac{0.8669 \mathrm{~kg}}{l} \times \frac{\mathrm{lb}}{0.454 \mathrm{~kg}}=1.81 \mathrm{lb}
$$

FF. Propane density $=0.5005 \mathrm{~kg} / \mathrm{l}$ at $20{ }^{\circ} \mathrm{C}$ for 100 percent concentration (Weast 1972 , p. C440)

$$
42.2 o z \times \frac{2.957 E-02 l}{o z} \times \frac{0.5005 \mathrm{~kg}}{l} \times \frac{\mathrm{lb}}{0.454 \mathrm{~kg}}=1.38 \mathrm{lb}
$$


Table A-4. Comparison of North Las Vegas Test Facility Chemical Inventory to Threshold Quantity and Threshold Planning Quantity Limits

\begin{tabular}{|c|c|c|c|c|c|c|}
\hline Location & Chemical & Inventory ${ }^{1}$ & $\begin{array}{c}29 \text { CFR } \\
1910.119 \\
\text { Threshold } \\
\text { Quantity } \\
\text { (lb) }\end{array}$ & $\begin{array}{l}40 \text { CFR 355 } \\
\text { Threshold } \\
\text { Planning } \\
\text { Quantity } \\
\text { (b) }\end{array}$ & $\begin{array}{c}40 \text { CFR } \\
68.125 \\
\text { Threshold } \\
\text { Quantity } \\
\text { (lb) }\end{array}$ & $\begin{array}{c}\text { Criteria } \\
\text { Exceeded? }\end{array}$ \\
\hline \multirow[t]{13}{*}{$\begin{array}{l}\text { Atlas Test } \\
\text { B-4 }\end{array}$} & $\begin{array}{l}\text { Sodium } \\
\text { hexameta- } \\
\text { phosphate }\end{array}$ & $1 \mathrm{gal}$ & NL & NL & NL & No \\
\hline & $\begin{array}{l}\text { Lithium } \\
\text { bromide }\end{array}$ & $1 \mathrm{~kg}$ & $\mathrm{NL}$ & NL & $\mathrm{NL}$ & No \\
\hline & $\begin{array}{l}\text { Sodium } \\
\text { bromide }\end{array}$ & $500 \mathrm{ml}$ & $\mathrm{NL}$ & NL & $\mathrm{NL}$ & No \\
\hline & $\begin{array}{l}\text { Potassium } \\
\text { chloride }\end{array}$ & $500 \mathrm{~g}$ & $\mathrm{NL}$ & NL & $\mathrm{NL}$ & No \\
\hline & $\begin{array}{l}\text { Calcium } \\
\text { iodide }\end{array}$ & $1 \mathrm{pt}$ & $\mathrm{NL}$ & NL & NL & No \\
\hline & $\begin{array}{l}\text { Potassium } \\
\text { hydroxide }\end{array}$ & 11 & NL & NL & NL & No \\
\hline & Nitric acid & $\begin{array}{l}250 \mathrm{ml} \\
(0.83 \mathrm{lb})^{\mathrm{A}}\end{array}$ & $\begin{array}{l}500 \\
(\geq 94.5 \%)\end{array}$ & 1000 & 15,000 & No \\
\hline & $\begin{array}{l}\text { Magnesium } \\
\text { chloride }\end{array}$ & $500 \mathrm{~g}$ & NL & $N L$ & NL & No \\
\hline & $\begin{array}{l}\text { Potassium } \\
\text { hydroxide }\end{array}$ & $500 \mathrm{~g}$ & NL & NL & $\mathrm{NL}$ & No \\
\hline & $\begin{array}{l}\text { Sodium } \\
\text { phosphate }\end{array}$ & $500 \mathrm{~g}$ & NL & NL & NL & No \\
\hline & $\begin{array}{l}\text { Aluminum } \\
\text { Ammonia } \\
\text { Sulphate }\end{array}$ & $100 \mathrm{~g}$ & NL & NL & $\mathrm{NL}$ & No \\
\hline & $\begin{array}{l}\text { Calcium } \\
\text { Chloride }\end{array}$ & $500 \mathrm{~g}$ & $\mathrm{NL}$ & $\mathrm{NL}$ & NL & No \\
\hline & $\begin{array}{l}\text { Iron II } \\
\text { chloride } \\
\text { hydrate }\end{array}$ & $25 \mathrm{~g}$ & NL & NL & NL & No \\
\hline
\end{tabular}

Inventory obtained from the M\&O Material Inventory Database.

$\mathrm{NL}$ - Not Listed; no TQ or TPQ was listed in the respective CFR

Inventory determination notes:

A. Nitric Acid density $=1.5040 \mathrm{~kg} / \mathrm{l}$ at $25^{\circ} \mathrm{C}$ for 100 percent concentration (Perry 1973, Table 368 , p. 3-76)

$$
250 \mathrm{ml} \times \frac{\mathrm{l}}{1000 \mathrm{ml}} \times \frac{1.504 \mathrm{~kg}}{l} \frac{\mathrm{lb}}{0.454 \mathrm{~kg}}=0.83 \mathrm{lb}
$$


Table A-5. Comparison of ESF Chemical Potentially Releasable Quantities to 40 CFR 302.4 Reportable Quantity Limits

\begin{tabular}{|c|c|c|c|c|c|c|}
\hline Location & Chemical & Inventory ${ }^{1}$ & $\mathbf{R F}^{2}$ & $\begin{array}{c}\text { Potentially } \\
\text { Releasable } \\
\text { Quantity (Ib) }\end{array}$ & $\begin{array}{c}40 \text { CFR } 302.4 \\
\text { Reportable } \\
\text { Quantity (Ib) }\end{array}$ & $\begin{array}{c}\text { Criteria } \\
\text { Exceeded? }\end{array}$ \\
\hline Bldg 4015 & Nitric acid & $\begin{array}{l}100 \mathrm{ml} \\
(0.33 \mathrm{lb})\end{array}$ & $1.0 \mathrm{E}-02$ & $3.3 \mathrm{E}-03$ & 1000 & No \\
\hline \multirow[t]{2}{*}{ Bldg 4221} & Aluminum oxide & $8 \mathrm{lb}$ & N/A & N/A & NL & No \\
\hline & Isopropyl alcohol & $4 \mathrm{gal}$ & N/A & N/A & $\mathrm{NL}$ & No \\
\hline \multirow[t]{3}{*}{ Bldg 4320} & Acetone & $\begin{array}{l}3 \mathrm{gal} \\
(19.76 \mathrm{lb})\end{array}$ & 0.5 & 9.88 & 5000 & No \\
\hline & $\begin{array}{l}\text { Diethylene } \\
\text { triamine }\end{array}$ & $5 \mathrm{gal}$ & N/A & N/A & $\mathrm{NL}$ & No \\
\hline & Hydrochloric acid & $\begin{array}{l}7 \mathrm{gal} \\
(69.92 \mathrm{lb})\end{array}$ & $1.0 \mathrm{E}-02$ & 0.70 & 5000 & No \\
\hline \multirow[t]{9}{*}{ Busted Butte } & Sodium fluoride & $\begin{array}{l}15 \mathrm{~g} \\
\text { (3.31E-02 } \\
\text { lb) }\end{array}$ & $1.0 \mathrm{E}-03$ & 3.31E-05 & 1000 & No \\
\hline & $\begin{array}{l}\text { Cobalt chloride } \\
\text { hexahydrate }\end{array}$ & $\begin{array}{l}2 \mathrm{~kg} \\
(4.41 \mathrm{lb}) \\
\end{array}$ & N/A & N/A & $N L$ & No \\
\hline & Sodium sulfate & $\begin{array}{l}500 \mathrm{~g} \\
(1.10 \mathrm{lb})\end{array}$ & N/A & N/A & $\mathrm{NL}$ & No \\
\hline & $\begin{array}{l}\text { Magnesium } \\
\text { sulfate }\end{array}$ & $\begin{array}{l}1000 \mathrm{~g} \\
(2.20 \mathrm{lb})\end{array}$ & N/A & N/A & $\mathrm{NL}$ & No \\
\hline & $\begin{array}{l}\text { Sodium } \\
\text { bicarbonate }\end{array}$ & $\begin{array}{l}1000 \mathrm{~g} \\
(2.20 \mathrm{lb})\end{array}$ & N/A & N/A & NL & No \\
\hline & $\begin{array}{l}\text { Potassium } \\
\text { bicarbonate }\end{array}$ & $\begin{array}{l}500 \mathrm{~g} \\
(1.10 \mathrm{lb})\end{array}$ & N/A & N/A & NL & No \\
\hline & Calcium chloride & $\begin{array}{l}1000 \mathrm{~g} \\
(2.20 \mathrm{lb}) \\
\end{array}$ & N/A & N/A & $\mathrm{NL}$ & No \\
\hline & Calcium nitrate & $\begin{array}{l}500 \mathrm{~g} \\
(1.10 \mathrm{lb})\end{array}$ & N/A & $N / A$ & NL & No \\
\hline & $\begin{array}{l}\text { Calcium } \\
\text { hydroxide }\end{array}$ & $\begin{array}{l}500 \mathrm{~g} \\
(1.10 \mathrm{lb}) \\
\end{array}$ & N/A & $\mathrm{N} / \mathrm{A}$ & $\mathrm{NL}$ & No \\
\hline \multirow[t]{5}{*}{ C Well Complex } & Acetonitrile & $\begin{array}{l}4 \mathrm{l} \\
(6.92 \mathrm{lb})\end{array}$ & 0.5 & 3.46 & 5000 & No \\
\hline & Methanol & 41 & $N / A$ & N/A & $\mathrm{NL}$ & No \\
\hline & Phosphoric acid & $\begin{array}{l}500 \mathrm{ml} \\
(2.06 \mathrm{lb})\end{array}$ & $1.0 \mathrm{E}-02$ & 0.02 & 5000 & No \\
\hline & Helium & 4 cylinders & N/A & N/A & NL & No \\
\hline & $\begin{array}{l}\text { Sodium } \\
\text { Hydroxide }\end{array}$ & $\begin{array}{l}3 \mathrm{~kg} \\
(1.36 \mathrm{lb})\end{array}$ & $1.0 \mathrm{E}-03$ & $1.4 \mathrm{E}-03$ & 1000 & No \\
\hline
\end{tabular}


Table A-5. Comparison of ESF Chemical Potentially Releasable Quantities to 40 CFR 302.4 Reportable Quantity Limits (Continued)

\begin{tabular}{|c|c|c|c|c|c|c|}
\hline Location & Chemical & Inventory ${ }^{1}$ & $\mathrm{RF}^{2}$ & $\begin{array}{l}\text { Potentially } \\
\text { Releasable } \\
\text { Quantity (Ib) }\end{array}$ & $\begin{array}{c}40 \text { CFR } 302.4 \\
\text { Reportable } \\
\text { Quantity (lb) }\end{array}$ & $\begin{array}{c}\text { Criteria } \\
\text { Exceeded? }\end{array}$ \\
\hline $\begin{array}{l}\text { Cabinet Outside } \\
\text { Bldg } 4215\end{array}$ & Isopropyl alcohol & $1 \mathrm{gal}$ & N/A & N/A & NL & No \\
\hline \multirow[t]{2}{*}{$\begin{array}{l}\text { Calibration Lab } \\
\text { Bldg } 4215\end{array}$} & Mercury & $\begin{array}{l}5 \mathrm{~g} \\
(0.01 \mathrm{lb})\end{array}$ & $1.0 \mathrm{E}-02$ & $1.0 \mathrm{E}-04$ & 1 & No \\
\hline & Sodium chloride & $1 \mathrm{~kg}$ & N/A & N/A & $\mathrm{NL}$ & No \\
\hline \multirow[t]{2}{*}{ Drilling Subdock } & Acetylene & $\begin{array}{l}250 \mathrm{ft}^{3} \\
(17.01 \mathrm{lb})\end{array}$ & N/A & N/A & $\mathrm{NL}$ & No \\
\hline & $\begin{array}{l}\text { Sulfur } \\
\text { hexafluoride }\end{array}$ & $2200 \mathrm{ft}^{3}$ & N/A & N/A & NL & No \\
\hline \multirow[t]{4}{*}{ ESF } & Lithium bromide & $159.44 \mathrm{~kg}$ & N/A & N/A & $\mathrm{NL}$ & No \\
\hline & $\begin{array}{l}\text { Carbon } \\
\text { monoxide }\end{array}$ & $60 \mathrm{ft}^{3}$ & N/A & N/A & $\mathrm{NL}$ & No \\
\hline & Ethanol & $8 \mathrm{oz}$ & N/A & N/A & $\mathrm{NL}$ & No \\
\hline & Aluminum oxide & $4 \mathrm{lb}$ & N/A & N/A & NL & No \\
\hline \multirow[t]{12}{*}{$\begin{array}{l}\text { ESF Pad Busted } \\
\text { Butte Pad }\end{array}$} & $\begin{array}{l}2,3,4,5 \text { tetra } \\
\text { fluorobenzoic } \\
\text { acid }\end{array}$ & $90 \mathrm{~g}$ & $N / A$ & N/A & NL & No \\
\hline & $\begin{array}{l}2,4,5 \text { trifluoro- } \\
\text { benzoic acid }\end{array}$ & $75 \mathrm{~g}$ & N/A & N/A & NL & No \\
\hline & $\begin{array}{l}2,6 \text { difluoro- } \\
\text { benzoic acid }\end{array}$ & $120 \mathrm{~g}$ & N/A & N/A & $\mathrm{NL}$ & No \\
\hline & $\begin{array}{l}\text { Cerium (III) } \\
\text { chloride } \\
\text { heptahydrate }\end{array}$ & $75 \mathrm{~g}$ & $N / A$ & $N / A$ & $\mathrm{NL}$ & No \\
\hline & Lithium bromide & $1.7 \mathrm{~kg}$ & N/A & N/A & $\mathrm{NL}$ & No \\
\hline & $\begin{array}{l}\text { Manganese } \\
\text { chloride } \\
\text { tetrahydrate }\end{array}$ & $2 \mathrm{~kg}$ & N/A & N/A & $\mathrm{NL}$ & No \\
\hline & $\begin{array}{l}\text { Nickel (III) } \\
\text { chloride } \\
\text { hexahydrate }\end{array}$ & $1 \mathrm{~kg}$ & $N / A$ & N/A & NL & No \\
\hline & Potassium iodide & $1.05 \mathrm{~kg}$ & $N / A$ & N/A & $\mathrm{NL}$ & No \\
\hline & Pyridone & $45 \mathrm{~g}$ & $\mathrm{~N} / \mathrm{A}$ & N/A & $\mathrm{NL}$ & No \\
\hline & $\begin{array}{l}\text { Samarium } \\
\text { Chloride } \\
\text { Hexahydrate }\end{array}$ & $75 \mathrm{~g}$ & N/A & N/A & $\mathrm{NL}$ & No \\
\hline & Sulfuric acid & $\begin{array}{l}100 \mathrm{ml} \\
(0.39 \mathrm{lb})\end{array}$ & $1.0 \mathrm{E}-02$ & $3.9 \mathrm{E}-03$ & 1000 & No \\
\hline & $\begin{array}{l}\text { Pentafluoro- } \\
\text { benzoic acid }\end{array}$ & $100 \mathrm{~g}$ & N/A & N/A & $\mathrm{NL}$ & No \\
\hline ESF South Portal & Acetylene & $\begin{array}{l}500 \mathrm{ft}^{3} \\
(34.01 \mathrm{lb})\end{array}$ & N/A & N/A & NL & No \\
\hline
\end{tabular}


Table A-5. Comparison of ESF Chemical Potentially Releasable Quantities to 40 CFR 302.4 Reportable Quantity Limits (Continued)

\begin{tabular}{|c|c|c|c|c|c|c|}
\hline Location & Chemical & Inventory ${ }^{1}$ & $\mathrm{RF}^{2}$ & $\begin{array}{c}\text { Potentially } \\
\text { Releasable } \\
\text { Quantity (lb) }\end{array}$ & $\begin{array}{c}40 \text { CFR } 302.4 \\
\text { Reportable } \\
\text { Quantity (lb) }\end{array}$ & $\begin{array}{c}\text { Criteria } \\
\text { Exceeded? }\end{array}$ \\
\hline $\begin{array}{l}\text { ESF Under- } \\
\text { ground }\end{array}$ & Acetylene & $\begin{array}{l}250 \mathrm{ft}^{3} \\
(17.01 \mathrm{lb})\end{array}$ & N/A & N/A & NL & No \\
\hline $\begin{array}{l}\text { ESF (QC } \\
\text { Complex) }\end{array}$ & $\begin{array}{l}\text { Sodium } \\
\text { hydroxide }\end{array}$ & $3 \mathrm{lb}$ & $1.0 \mathrm{E}-03$ & 3.0E-03 & 1000 & No \\
\hline \multirow[t]{2}{*}{ ESF (Mechanics) } & Acetylene & $\begin{array}{l}1500 \mathrm{ft}^{3} \\
(102.06 \mathrm{lb})\end{array}$ & N/A & N/A & NL & No \\
\hline & Isopropyl alcohol & $16 \mathrm{oz}$ & N/A & N/A & NL & No \\
\hline \multirow[t]{2}{*}{ ESF (Painters) } & Muriatic acid & $4 \mathrm{gal}$ & N/A & N/A & NL & No \\
\hline & Isopropyl alcohol & $1 \mathrm{gal}$ & N/A & N/A & $\mathrm{NL}$ & No \\
\hline ESF (Pipe Fitters) & Propane & $\begin{array}{l}99 \mathrm{oz} \\
(3.23 \mathrm{lb})\end{array}$ & N/A & N/A & $\mathrm{NL}$ & No \\
\hline \multirow[t]{2}{*}{ ESF (Tool Crib) } & Toluene & $\begin{array}{l}3 \mathrm{qt} \\
(5.44 \mathrm{lb})\end{array}$ & 0.5 & 2.72 & 1000 & No \\
\hline & Propane & $2048 \mathrm{oz}$ & N/A & N/A & $\mathrm{NL}$ & No \\
\hline \multirow[t]{2}{*}{ ESF Warehouse } & Muriatic acid & $11 \mathrm{gal}$ & N/A & N/A & NL & No \\
\hline & $\begin{array}{l}\text { Calcium Hypo- } \\
\text { chlorite }\end{array}$ & $100 \mathrm{lb}$ & $1.0 \mathrm{E}-03$ & 0.10 & 10 & No \\
\hline $\begin{array}{l}\text { FSC at } \\
\text { Reclamation } \\
\text { Storage Area }\end{array}$ & Butane & $\begin{array}{l}30 \mathrm{oz} \\
(1.17 \mathrm{lb})\end{array}$ & N/A & N/A & NL & No \\
\hline HRF BIdg 4125 & $\begin{array}{l}\text { 7-amino-1-3- } \\
\text { Naphthalene } \\
\text { disulfonic acid }\end{array}$ & $1 \mathrm{~kg}$ & N/A & N/A & $\mathrm{NL}$ & No \\
\hline \multirow[t]{9}{*}{$\begin{array}{l}\text { Hydrochem/ } \\
\text { Geophysical Labs } \\
\text { Bldg } 4215\end{array}$} & Acetonitrile & $\begin{array}{l}21 \\
(3.46 \mathrm{lb}) \\
\end{array}$ & 0.5 & 1.73 & 5000 & No \\
\hline & $\begin{array}{l}\text { Barium chloride } \\
\text { dihydrate }\end{array}$ & $1000 \mathrm{~g}$ & $N / A$ & N/A & NL & No \\
\hline & Mercuric chloride & $100 \mathrm{~g}$ & N/A & N/A & NL & No \\
\hline & Methanol & 41 & N/A & N/A & $\mathrm{NL}$ & No \\
\hline & Nitric acid & $\begin{array}{l}1 \mathrm{ml} \\
(3.31 \mathrm{E}-01 \\
\mathrm{lb})\end{array}$ & 1.0E-02 & 3.31E-03 & 1000 & No \\
\hline & $\begin{array}{l}\text { Barium chloride, } \\
\text { anhydrous }\end{array}$ & $500 \mathrm{~g}$ & N/A & N/A & $\mathrm{NL}$ & No \\
\hline & $\begin{array}{l}\text { 4-(2-pyridylazo) } \\
\text { resorcinol }\end{array}$ & $\begin{array}{l}5 \mathrm{~g} \\
(0.01 \mathrm{lb})\end{array}$ & N/A & N/A & $\mathrm{NL}$ & No \\
\hline & $\begin{array}{l}\text { 4-methyl-2- } \\
\text { pentanone }\end{array}$ & 11 & N/A & $N / A$ & NL & No \\
\hline & $\begin{array}{l}\text { Acetic acid, } \\
\text { sodium salt } \\
\text { trihydrate }\end{array}$ & $500 \mathrm{~g}$ & N/A & N/A & NL & No \\
\hline
\end{tabular}


Table A-5. Comparison of ESF Chemical Potentially Releasable Quantities to 40 CFR 302.4 Reportable Quantity Limits (Continued)

\begin{tabular}{|c|c|c|c|c|c|c|}
\hline Location & Chemical & Inventory & $\mathrm{RF}^{2}$ & $\begin{array}{l}\text { Potentially } \\
\text { Releasable } \\
\text { Quantity (lb) }\end{array}$ & $\begin{array}{c}40 \text { CFR } 302.4 \\
\text { Reportable } \\
\text { Quantity (b) }\end{array}$ & $\begin{array}{c}\text { Criteria } \\
\text { Exceeded? }\end{array}$ \\
\hline \multirow[t]{16}{*}{$\begin{array}{l}\text { Hydrochem/ } \\
\text { Geophysical Labs } \\
\text { Bldg } 4215 \text { (cont'd) }\end{array}$} & $\begin{array}{l}\text { Ammonium } \\
\text { hydroxide }(30 \%)\end{array}$ & $\begin{array}{l}4 \mathrm{I} \\
(8.25 \mathrm{lb}) \\
\end{array}$ & $1.0 \mathrm{E}-03$ & 0.01 & 1000 & No \\
\hline & $\begin{array}{l}\text { Hydroxyl amnine } \\
\text { hydro-chloride }\end{array}$ & $100 \mathrm{~g}$ & N/A & $N / A$ & $\mathrm{NL}$ & No \\
\hline & $\begin{array}{l}\text { Lanthanum } \\
\text { chloride }\end{array}$ & $250 \mathrm{~g}$ & $N / A$ & $N / A$ & $\mathrm{NL}$ & No \\
\hline & $\begin{array}{l}\text { Lanthanum } \\
\text { chloride, } 7 \text { - } \\
\text { hydrate }\end{array}$ & $75 \mathrm{~g}$ & N/A & $N / A$ & $\mathrm{NL}$ & No \\
\hline & $\begin{array}{l}\text { Magnesium } \\
(1000 \mathrm{ppm})\end{array}$ & $500 \mathrm{ml}$ & $N / A$ & N/A & $\mathrm{NL}$ & No \\
\hline & $\begin{array}{l}\text { Oxalic acid, } \\
\text { anhydrous }\end{array}$ & $50 \mathrm{~g}$ & $N / A$ & N/A & $\mathrm{NL}$ & No \\
\hline & $\begin{array}{l}\text { Sodium } \\
\text { hydroxide } 10 \mathrm{~N} \\
\text { soln. }\end{array}$ & $\begin{array}{l}51 \\
(4.41 \mathrm{lb})\end{array}$ & $1.0 \mathrm{E}-03$ & $4.41 \mathrm{E}-03$ & 1000 & No \\
\hline & $\begin{array}{l}\text { Sodium sulfite, } \\
\text { anhydrous }\end{array}$ & $500 \mathrm{~g}$ & $N / A$ & N/A & $\mathrm{NL}$ & No \\
\hline & $\begin{array}{l}\text { Strontium } \\
\text { chloride, } 6 \\
\text { hydrate crystal }\end{array}$ & $500 \mathrm{~g}$ & N/A & N/A & $\mathrm{NL}$ & No \\
\hline & $\begin{array}{l}\text { Strontium } 1000 \\
\text { ppm }\end{array}$ & $500 \mathrm{ml}$ & N/A & N/A & $\mathrm{NL}$ & No \\
\hline & $\begin{array}{l}\text { Sodium } \\
\text { hydroxide }\end{array}$ & $\begin{array}{l}125 \mathrm{~g} \\
(0.28 \mathrm{lb})\end{array}$ & $1.0 \mathrm{E}-03$ & $2.8 \mathrm{E}-04$ & 1000 & No \\
\hline & $\begin{array}{l}1,10 \text { phenanthro- } \\
\text { line, mono- } \\
\text { hydrate }\end{array}$ & $5 \mathrm{~g}$ & N/A & N/A & NL & No \\
\hline & $\begin{array}{l}2,3 \text { diamino } \\
\text { prionic acid } \\
\text { monohydro } \\
\text { chloride }\end{array}$ & $5 \mathrm{~g}$ & N/A & $N / A$ & $\mathrm{NL}$ & No \\
\hline & $\begin{array}{l}\text { Sulfuric acid } \\
(85 \%)\end{array}$ & $\begin{array}{l}71 \\
(27.34 \mathrm{lb})\end{array}$ & $1.0 \mathrm{E}-02$ & 0.27 & 1000 & No \\
\hline & Acetonitrile & $\begin{array}{l}21 \\
(3.46 \mathrm{lb}) \\
\end{array}$ & .5 & 1.73 & 5000 & No \\
\hline & 8-Quinolinol & $5 \mathrm{~g}$ & N/A & N/A & $\mathrm{NL}$ & No \\
\hline \multirow[t]{5}{*}{$\begin{array}{l}\text { Hydrology Lab } \\
\text { Bldg } 4215\end{array}$} & Aluminum oxide & $2.5 \mathrm{~kg}$ & N/A & N/A & $\mathrm{NL}$ & No \\
\hline & Methanol & 11 & N/A & N/A & $\mathrm{NL}$ & No \\
\hline & Aluminum Oxide & $1 \mathrm{lb}$ & N/A & N/A & $\mathrm{NL}$ & No \\
\hline & Mercury & $75 \mathrm{lb}$ & $1.0 \mathrm{E}-02$ & 0.75 & 1 & No \\
\hline & $\begin{array}{l}\text { Potassium } \\
\text { Bicarbonate }\end{array}$ & $500 \mathrm{~g}$ & N/A & N/A & NL & No \\
\hline
\end{tabular}


Table A-5. Comparison of ESF Chemical Potentially Releasable Quantities to 40 CFR 302.4 Reportable Quantity Limits (Continued)

\begin{tabular}{|c|c|c|c|c|c|c|}
\hline Location & Chemical & Inventory ${ }^{1}$ & $\mathbf{R F}^{2}$ & $\begin{array}{c}\text { Potentially } \\
\text { Releasable } \\
\text { Quantity (lb) }\end{array}$ & $\begin{array}{c}40 \text { CFR } 302.4 \\
\text { Reportable } \\
\text { Quantity (lb) }\end{array}$ & $\begin{array}{c}\text { Criteria } \\
\text { Exceeded? }\end{array}$ \\
\hline \multirow[t]{17}{*}{$\begin{array}{l}\text { Hydrology Lab } \\
\text { Bldg } 4215 \text { (cont'd) }\end{array}$} & Acetone & $\begin{array}{l}41 \\
(6.96 \mathrm{lb})\end{array}$ & .5 & 3.48 & 5000 & No \\
\hline & $\begin{array}{l}\text { Aluminum Nitrate } \\
\text { 9-hydrate }\end{array}$ & $10 \mathrm{lb}$ & N/A & N/A & $\mathrm{NL}$ & No \\
\hline & $\begin{array}{l}\text { Calcium } \\
\text { Selenate }(99 \%)\end{array}$ & $438 \mathrm{~g}$ & $N / A$ & N/A & NL & No \\
\hline & Calcium Sulfate & $500 \mathrm{~g}$ & N/A & N/A & NL & No \\
\hline & Helium & 1 cylinder & N/A & N/A & $\mathrm{NL}$ & No \\
\hline & Isopropyl alcohol & $1 \mathrm{gal}$ & N/A & $\mathrm{N} / \mathrm{A}$ & $\mathrm{NL}$ & No \\
\hline & Potassium iodine & $2 \mathrm{lb}$ & $N / A$ & $N / A$ & $\mathrm{NL}$ & No \\
\hline & $\begin{array}{l}\text { Potassium } \\
\text { nitrate }\end{array}$ & $500 \mathrm{~g}$ & N/A & N/A & $\mathrm{NL}$ & No \\
\hline & $\begin{array}{l}\text { Potassium } \\
\text { sulfate }\end{array}$ & $500 \mathrm{~g}$ & N/A & N/A & NL & No \\
\hline & $\begin{array}{l}\text { Sodium } \\
\text { carbonate, } \\
\text { anhydrous }\end{array}$ & $1 \mathrm{lb}$ & N/A & N/A & $\mathrm{NL}$ & No \\
\hline & $\begin{array}{l}\text { Sodium pyro- } \\
\text { phosphate }\end{array}$ & $2.5 \mathrm{~kg}$ & N/A & N/A & NL & No \\
\hline & Cupric sulfate & $\begin{array}{l}2.27 \mathrm{~kg} \\
(5.00 \mathrm{lb})\end{array}$ & $1.0 \mathrm{E}-03$ & $5.00 \mathrm{E}-3$ & 10 & No \\
\hline & Lithium chloride & $1500 \mathrm{~g}$ & $\mathrm{~N} / \mathrm{A}$ & $\mathrm{N} / \mathrm{A}$ & $\mathrm{NL}$ & No \\
\hline & $\begin{array}{l}\text { Potassium } \\
\text { chloride }\end{array}$ & $1000 \mathrm{~g}$ & N/A & N/A & NL & No \\
\hline & $\begin{array}{l}\text { Sodium } \\
\text { hydroxide (50\%) }\end{array}$ & $\begin{array}{l}1 \mathrm{pt} \\
(1.59 \mathrm{lb})\end{array}$ & $1.0 \mathrm{E}-03$ & $1.59 \mathrm{E}-03$ & 1000 & No \\
\hline & Sodium chloride & $1500 \mathrm{~g}$ & N/A & N/A & NL & No \\
\hline & $\begin{array}{l}\text { Magnesium } \\
\text { sulfate }\end{array}$ & $500 \mathrm{~g}$ & N/A & $N / A$ & $\mathrm{NL}$ & No \\
\hline Mine Rescue & Methane & $\begin{array}{l}4 \mathrm{ft}^{3} \\
(0.18 \mathrm{lb})\end{array}$ & $N / A$ & N/A & NL & No \\
\hline $\begin{array}{l}\text { Reclamation } \\
\text { Storage Area }\end{array}$ & Nitrogen & $510 \mathrm{ft}^{3}$ & N/A & N/A & NL & No \\
\hline $\begin{array}{l}\text { Reclamation } \\
\text { Storage Area } \\
\text { Boxcar }\end{array}$ & $\begin{array}{l}\text { Sodium } \\
\text { hydroxide }\end{array}$ & $1000 \mathrm{lb}$ & $1.0 \mathrm{E}-03$ & 1.00 & 1000 & No \\
\hline $\begin{array}{l}\text { Site 1, NTS-60 } \\
\text { (tower) }\end{array}$ & Isopropyl alcohol & $64 \mathrm{oz}$ & N/A & N/A & NL & No \\
\hline $\begin{array}{l}\text { Site Maintenance } \\
\text { Bldg } 4222\end{array}$ & Acetylene & $\begin{array}{l}1 \text { cylinder } \\
\left(250 \mathrm{ft}^{3}\right) \\
(17.01 \mathrm{lb})\end{array}$ & $N / A$ & $N / A$ & $\mathrm{NL}$ & No \\
\hline & Hydrochloric acid & $\begin{array}{l}1.1 \mathrm{pt} \\
(1.37 \mathrm{lb})\end{array}$ & $1.0 \mathrm{E}-02$ & 0.01 & 5000 & No \\
\hline
\end{tabular}


Table A-5. Comparison of ESF Chemical Potentially Releasable Quantities to 40 CFR 302.4 Reportable Quantity Limits (Continued)

\begin{tabular}{|c|c|c|c|c|c|c|}
\hline Location & Chemical & Inventory ${ }^{1}$ & $\mathbf{R F}^{2}$ & $\begin{array}{c}\text { Potentially } \\
\text { Releasable } \\
\text { Quantity (Ib) }\end{array}$ & $\begin{array}{c}40 \text { CFR } 302.4 \\
\text { Reportable } \\
\text { Quantity (b) }\end{array}$ & $\begin{array}{c}\text { Criteria } \\
\text { Exceeded? }\end{array}$ \\
\hline \multirow[t]{4}{*}{$\begin{array}{l}\text { Site Maintenance } \\
\text { Bldg } 4222 \text { (cont'd) }\end{array}$} & Propane & $\begin{array}{l}5 \text { tanks } \\
(55-\mathrm{lb} \\
\text { tanks; } 35 \mathrm{lb} \\
\text { total) }\end{array}$ & N/A & N/A & $\mathrm{NL}$ & No \\
\hline & $\begin{array}{l}\text { Sulfur hexa- } \\
\text { fluoride }\end{array}$ & 10 tanks & $N / A$ & N/A & $\mathrm{NL}$ & No \\
\hline & Carbon dioxide & 1 tank & $N / A$ & N/A & NL & No \\
\hline & Argon & 1 bottle & N/A & N/A & NL & No \\
\hline \multirow[t]{5}{*}{$\begin{array}{l}\text { Soils Lab BIdg } \\
4222\end{array}$} & Acetone & $\begin{array}{l}27.36 \mathrm{I} \\
(47.6 \mathrm{lb}) \\
\end{array}$ & .5 & 23.8 & 5000 & No \\
\hline & $\begin{array}{l}\text { Hydrochloric acid } \\
1 \mathrm{~N} \text { soln. }\end{array}$ & $\begin{array}{l}1.5 \mathrm{I} \\
(0.12 \mathrm{lb})\end{array}$ & $1.0 \mathrm{E}-02$ & $1.2 \mathrm{E}-03$ & 5000 & No \\
\hline & $\begin{array}{l}\text { Hydrochloric acid } \\
\text { trace metals }\end{array}$ & 101 & $N / A$ & $N / A$ & $\mathrm{NL}$ & No \\
\hline & $\begin{array}{l}\text { Sodium } \\
\text { hydroxide (50\%) }\end{array}$ & $\begin{array}{l}500 \mathrm{ml} \\
(1.68 \mathrm{lb})\end{array}$ & $1.0 \mathrm{E}-03$ & $1.68 \mathrm{E}-03$ & 1000 & No \\
\hline & $\begin{array}{l}\text { Sodium } \\
\text { hydroxide } 1 \mathrm{~N} \\
\text { soln. }\end{array}$ & $\begin{array}{l}11 \\
(0.09 \mathrm{lb})\end{array}$ & $1.0 \mathrm{E}-03$ & $9.0 E-05$ & 1000 & No \\
\hline \multirow[t]{2}{*}{ Tracer Trailer } & Argon & 2 tanks & $N / A$ & $\mathrm{~N} / \mathrm{A}$ & NL & No \\
\hline & Helium & 1 tank & N/A & N/A & $\mathrm{NL}$ & No \\
\hline \multirow[t]{4}{*}{$\begin{array}{l}\text { Waste } \\
\text { Management Area }\end{array}$} & $\begin{array}{l}\text { Carbon } \\
\text { tetrachloride }\end{array}$ & $\begin{array}{l}580 \mathrm{ml} \\
(2.04 \mathrm{lb})\end{array}$ & $1.0 \mathrm{E}-02$ & 0.02 & 5000 & No \\
\hline & $\begin{array}{l}\text { Aluminum } \\
\text { chloride } \\
\text { anhydrous }\end{array}$ & $44 \mathrm{~g}$ & $\mathrm{~N} / \mathrm{A}$ & N/A & $\mathrm{NL}$ & No \\
\hline & Toluene & $\begin{array}{l}1 \mathrm{qt} \\
(1.81 \mathrm{lb})\end{array}$ & 0.5 & 0.91 & 1000 & No \\
\hline & Propane & $\begin{array}{l}42.2 \mathrm{oz} \\
(1.38 \mathrm{lb})\end{array}$ & $N / A$ & N/A & $\mathrm{NL}$ & No \\
\hline
\end{tabular}

${ }^{1}$ Inventory quantities calculated in Table A-3 are carried over to Table A-4.

${ }^{2}$ As reported in DOE-STD-1027-92

N/A - Not Applicable, there is no Reportable Quantity

NL - Not Listed in 40 CFR 302.4 
Table A-6. Comparison of North Las Vegas Test Facility Chemical Potentially Releasable Quantities to 40 CFR 302.4 Reportable Quantity Limits

\begin{tabular}{|l|l|l|l|l|l|l|}
\hline Location & \multicolumn{1}{|c|}{ Chemical } & Inventory & \multicolumn{1}{|c|}{ RF $^{1}$} & $\begin{array}{c}\text { Potentially } \\
\text { Releasable } \\
\text { Quantity (Ib) }\end{array}$ & $\begin{array}{c}\text { 40 CFR 302.4 } \\
\text { Reportable } \\
\text { Quantity (lb) }\end{array}$ & $\begin{array}{c}\text { Criteria } \\
\text { Exceeded? }\end{array}$ \\
\hline Atlas Test & $\begin{array}{l}\text { Sodium } \\
\text { hexameta- } \\
\text { phosphate }\end{array}$ & $1 \mathrm{gal}$ & N/A & N/A & NL & No \\
\hline & Lithium bromide & $1 \mathrm{~kg}$ & N/A & N/A & NL & No \\
\hline & Sodium bromide & $500 \mathrm{ml}$ & N/A & N/A & NL & No \\
\hline & $\begin{array}{l}\text { Potassium } \\
\text { chloride }\end{array}$ & $500 \mathrm{~g}$ & N/A & N/A & NL & No \\
\hline & Calcium iodide & $1 \mathrm{pt}$ & N/A & N/A & NL & No \\
\hline & $\begin{array}{l}\text { Potassium } \\
\text { hydroxide } \\
\text { (solution) }\end{array}$ & $\begin{array}{l}11 \\
(3.38 \mathrm{lb})^{\mathrm{A}}\end{array}$ & $1.0 \mathrm{E}-02$ & 0.03 & 1000 & No \\
\hline & Nitric acid & $\begin{array}{l}250 \mathrm{ml} \\
(0.83 \mathrm{lb})^{\mathrm{B}}\end{array}$ & $1.0 \mathrm{E}-02$ & 0.01 & 1000 & No \\
\hline & $\begin{array}{l}\text { Magnesium } \\
\text { chloride }\end{array}$ & $500 \mathrm{~g}$ & N/A & N/A & NL & No \\
\hline & $\begin{array}{l}\text { Potassium } \\
\text { hydroxide }\end{array}$ & $\begin{array}{l}500 \mathrm{~g} \\
(1.10 \mathrm{lb})\end{array}$ & $1.0 \mathrm{E}-03$ & $1.10 \mathrm{E}-03$ & 1000 & No \\
\hline & $\begin{array}{l}\text { Sodium } \\
\text { phosphate }\end{array}$ & $\begin{array}{l}500 \mathrm{~g} \\
(1.10 \mathrm{lb})\end{array}$ & $1.0 \mathrm{E}-03$ & $1.10 \mathrm{E}-03$ & 5000 & No \\
\hline & $\begin{array}{l}\text { Aluminum } \\
\text { ammonium } \\
\text { sulfate }\end{array}$ & $100 \mathrm{~g}$ & N/A & N/A & NL & No \\
\hline & $\begin{array}{l}500 \mathrm{~g} \\
(1.10 \mathrm{lb})\end{array}$ & $1.0 \mathrm{E}-03$ & $1.10 \mathrm{E}-03$ & 10 & No \\
\hline & $\begin{array}{l}\text { Calcium chloride } \\
\text { lron II chloride } \\
\text { hydrate }\end{array}$ & $25 \mathrm{~g}$ & N/A & N/A & & NL \\
\hline
\end{tabular}

As reported in DOE-STD-1027-92

N/A - Not Applicable, there is no Reportable Quantity

$\mathrm{NL}-$ Not Listed in 40 CFR 302.4

Inventory determination notes:

A. Potassium Hydroxide density $=1.5355 \mathrm{~kg} / 1$ at $25^{\circ} \mathrm{C}$ for 51.7 percent concentration (saturated solution) (Perry 1973, Table 3-78, p. 3-78)

$$
1 l \times \frac{1.5355 \mathrm{~kg}}{l} \frac{\mathrm{lb}}{0.454 \mathrm{~kg}}=3.38 \mathrm{lb}
$$


B. Nitric Acid density $=1.5040 \mathrm{~kg} / 1$ at $25^{\circ} \mathrm{C}$ for 100 percent concentration (Perry 1973, Table $3-68$, p. 3-76)

$$
250 \mathrm{ml} \times \frac{\mathrm{l}}{1000 \mathrm{ml}} \times \frac{1.504 \mathrm{~kg}}{l} \frac{\mathrm{lb}}{0.454 \mathrm{~kg}}=0.83 \mathrm{lb}
$$




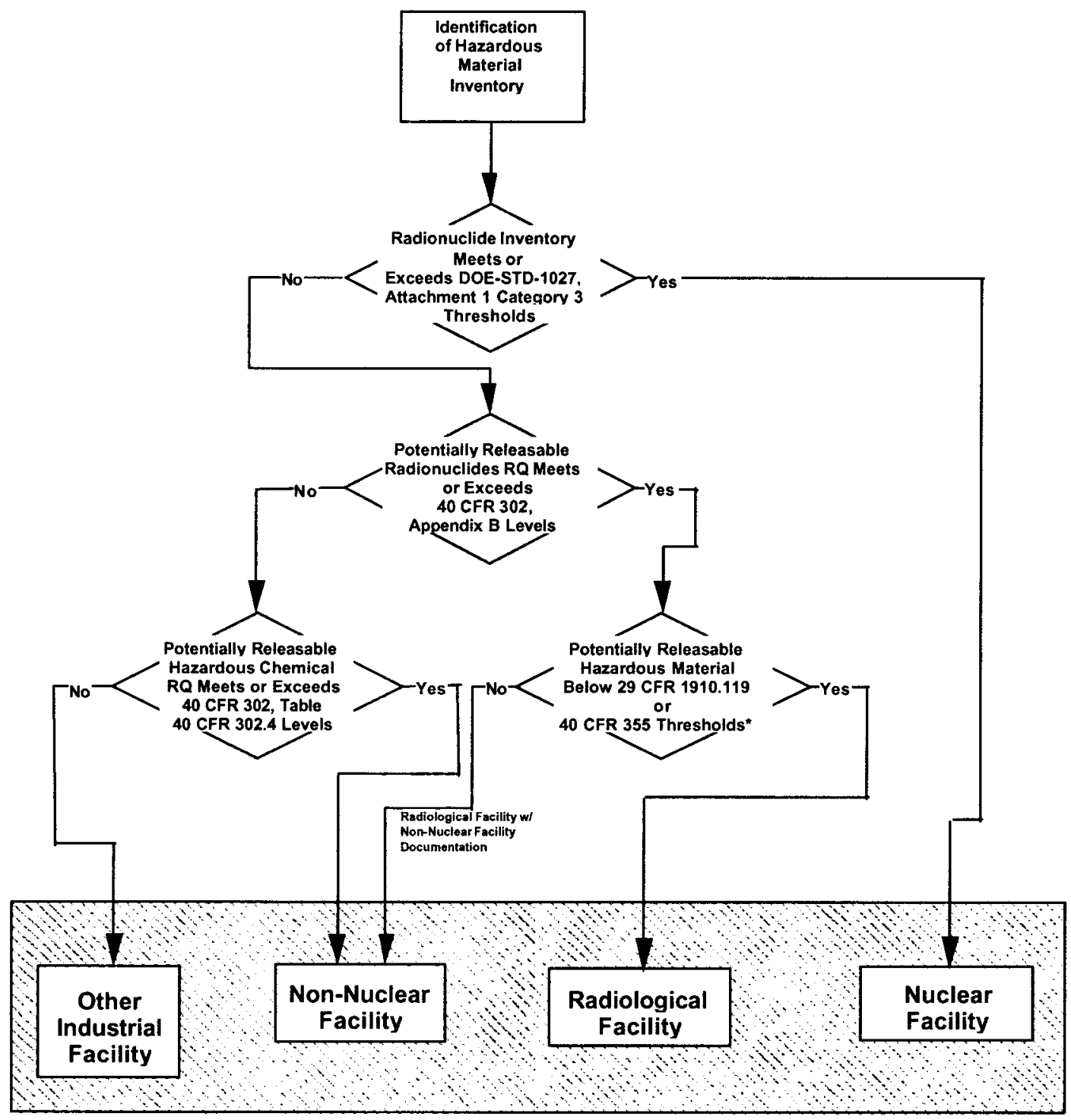

Hazard Baseline Grouping

*If chemicals are not listed in 29CFR1910.119

Figure A-1. Determination of Hazard Baseline Grouping 


\section{INTENTIONALLY LEFT BLANK}

